\title{
RESISTANCE REVERSING ACTIVITY OF PLANT-DERIVED AND NOVEL SYNTHETIC COMPOUNDS IN BACTERIAL MODELS
}

\author{
Ph.D. Thesis
}

\section{Annamária Kincses}

Supervisor: Gabriella Spengler, Ph.D.

\author{
Department of Medical Microbiology and Immunobiology \\ Faculty of Medicine \\ University of Szeged
}

Szeged

2019 


\section{CONTENTS}

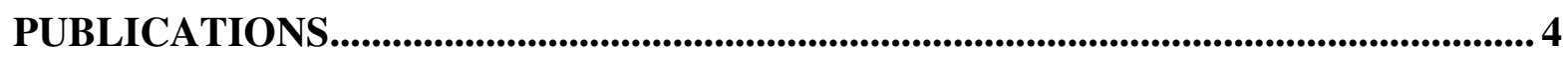

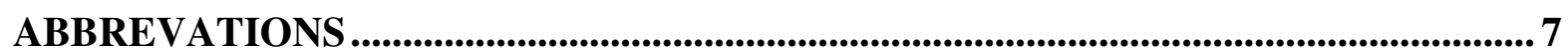

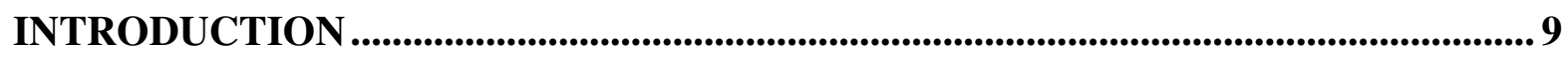

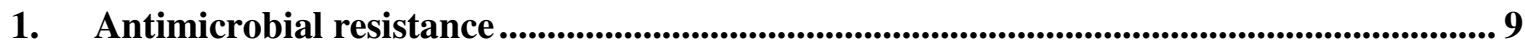

2. Horizontal gene transfer mechanisms …............................................................................ 10

3. Mechanisms of acquired antimicrobial resistance ............................................................ 12

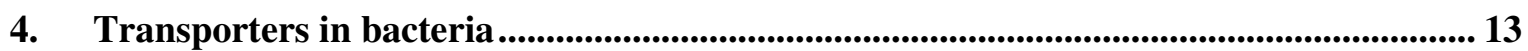

5. Biofilm formation and quorum sensing......................................................................................... 16

6. Background of resistance modulators applied in this study............................................... 17

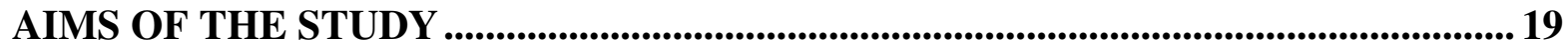

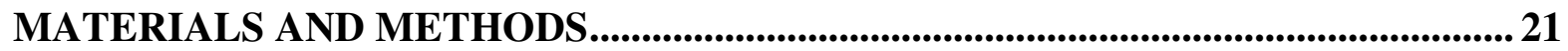

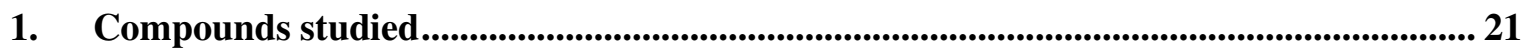

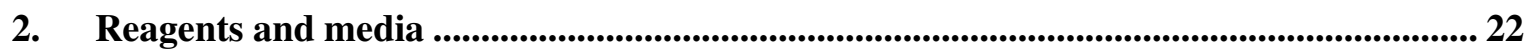

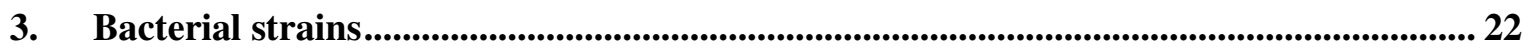

4. Determination of minimum inhibitory concentrations by microdilution method........... 23

5. Real-time accumulation assay by Roche LightCycler real-time thermocycler................. 23

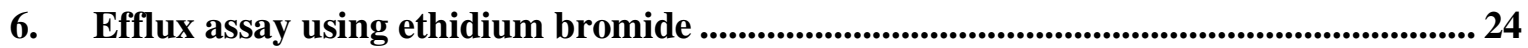

7. Measuring biofilm formation using crystal violet ....................................................................... 25

8. Interaction between antibiotics and resistance modifiers using checkerboard method 25

9. Interaction between antibiotics and resistance modifiers using minimum inhibitory

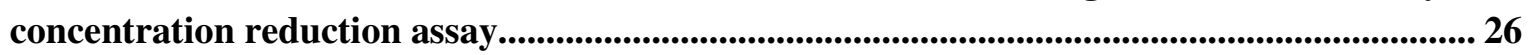

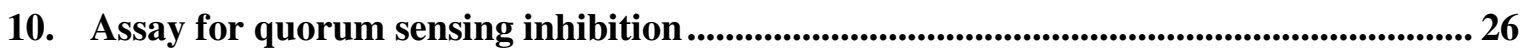

11. Expression analyses of genes by RT-qPCR reaction................................................................ 27

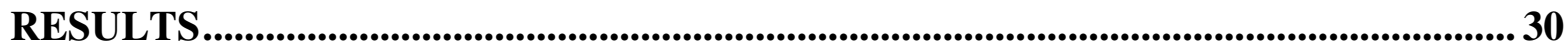

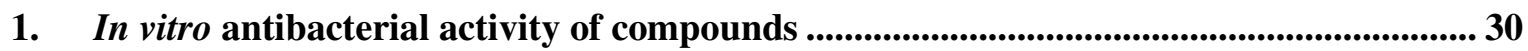

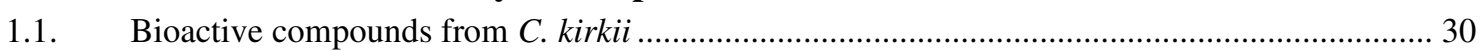

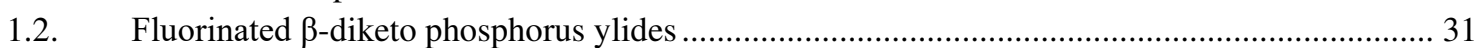

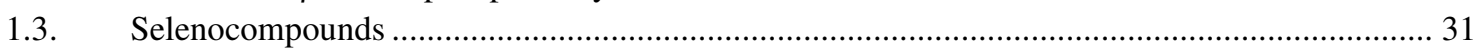

2. Efflux pump inhibiting activity (accumulation assay) ........................................................... 31

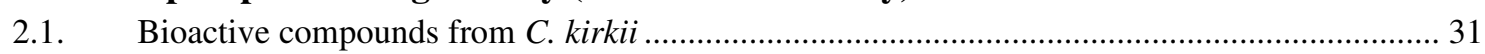

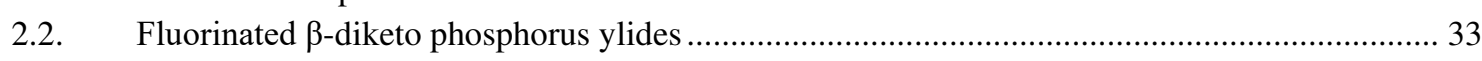

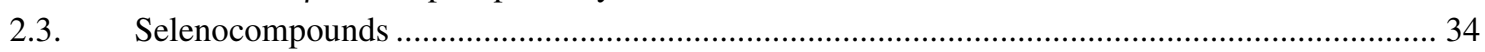

3. Efflux pump inhibiting activity (efflux assay) .................................................................. 35

4. Anti-biofilm activity of selenocompounds..................................................................................... 36

5. Combined effects of chamanetin (CK2) and dichamanetin (CK4) with antibiotics....... 37 
6. Enhancement of the activity of antibiotics in the presence of selenocompounds ............ 38

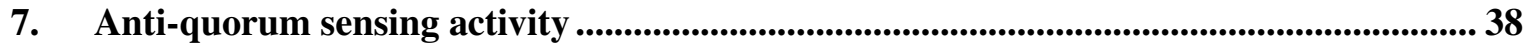

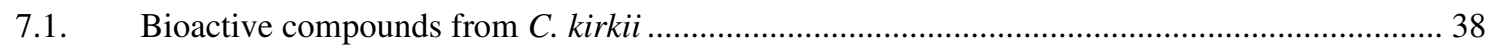

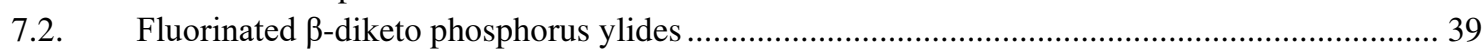

8. Relative expressions of genes related to antibiotic resistance, quorum sensing and efflux

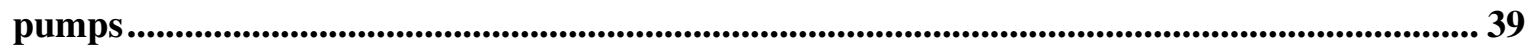

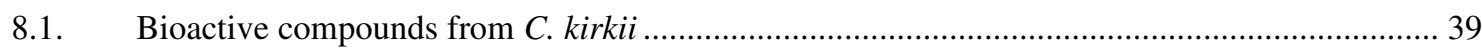

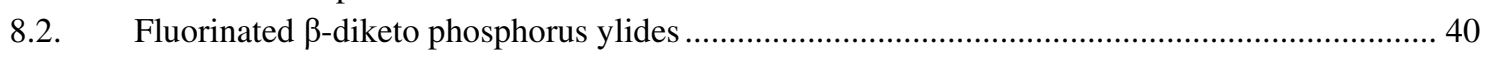

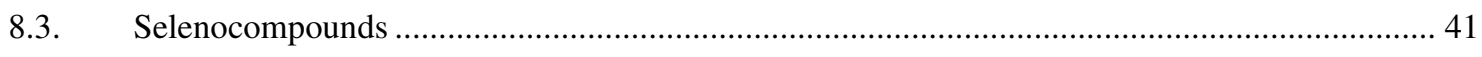

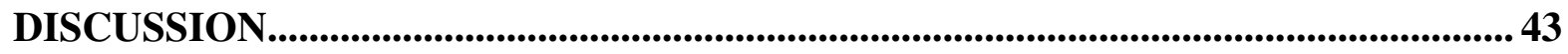

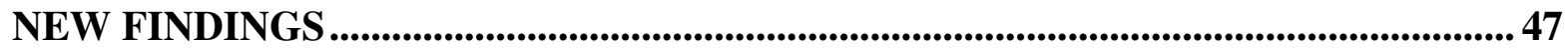

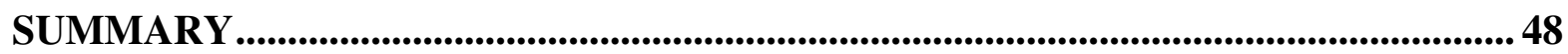

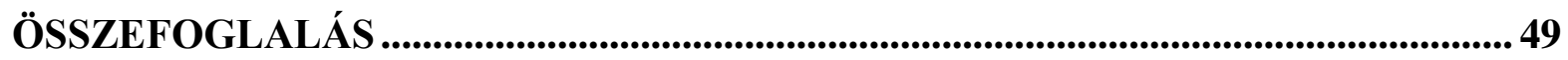

REFERENCES …..........................................................................................................................................5 50

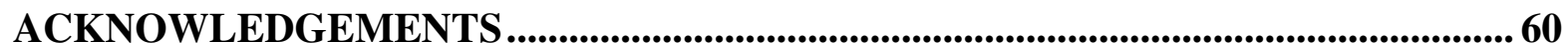

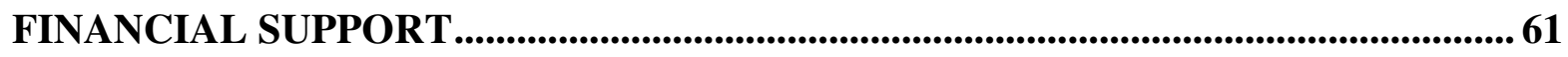

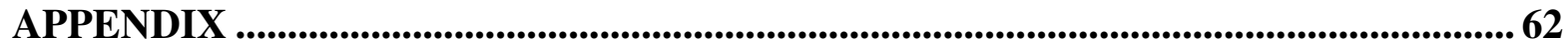

TÁRSSZERZÖI LEMONDÓ NYILATKOZAT _....................................................69

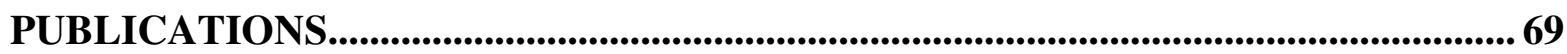




\section{PUBLICATIONS}

\section{Publications related to the thesis}

I. Kincses A, Szabó ÁM, Saijo R, Watanabe G, Kawase M, Molnár J, Spengler G. Fluorinated $\beta$-diketo phosphorus ylides are novel efflux pump inhibitors in bacteria. In Vivo. 30: 813-17, 2017.

IF: 0.953

II. Kincses A, Varga B, Csonka A, Sancha S, Mulhovo S, Madureira AM, Ferreira MJU, Spengler G. Bioactive compounds from the African medicinal plant Cleistochlamys kirkii as resistance modifiers in bacteria. Phytother Res. 32: 1039-46, 2018.

\section{IF: 3.766}

III. Mosolygó T, Kincses A, Csonka A, Tönki ÁS, Witek K, Sanmartín C, Marć MA, Handzlik J, Kieć-Kononowicz K, Domínguez-Álvarez E, Spengler G. Selenocompounds as novel antibacterial agents and bacterial efflux pump inhibitors. Molecules. 24: E1487, 2019.

\section{IF: 3.06}

IV. Kincses A, Spengler G. Szelénvegyületek efflux pumpa és biofilm gátló hatásának vizsgálata Salmonella Typhimurium törzseken. Tudományos eredmények a nagyvilágból: Válogatás a Campus mundi ösztöndíjasok tanulmányaiból. ISBN 978615-5319-64-8, 2019.

IF: -

\section{Total IF: 7.779}

\section{Publications not related to the thesis}

I. Żesławska E, Kincses A, Spengler G, Nitek W, Wyrzuc K, Kieć-Kononowicz K, Handzlik J. The 5-aromatic hydantoin-3-acetate derivatives as inhibitors of the tumour multidrug resistance efflux pump P-glycoprotein (ABCB1): Synthesis, crystallographic and biological studies. Bioorg Med Chem. 24: 2815-22, 2016.

IF: 2.93

II. Paterna A, Kincses A, Spengler G, Mulhovo S, Molnar J, Ferreira MJU. Dregamine and tabernaemontanine derivatives as ABCB1 modulators on resistant cancer cells. Eur J Med Chem. 128: 247-57, 2017.

\section{F: 4.816}

III. Spengler G, Kincses A, Gajdács M, Amaral L. New roads leading to old destinations: efflux pumps as targets to reverse multidrug resistance in bacteria. Molecules. 22: E468, 2017.

IF: 3.098 
IV. Magyari J, Barta Holló B, Vojinovic-Jesic L, Radanovic M, Armakovic S, Armakovic S, Molnar J, Kincses A, Gajdács M, Spengler G, Mészáros Szécsényi K. Interactions of Schiff base type compounds and their coordination complexes with the anticancer drug cisplatin. New J Chem. 42: 5834-43, 2018.

IF: 3.069

V. Rédei D, Kúsz N, Sátori G, Kincses A, Spengler G, Burián K, Sarina Z, Hohmann J. Bioactive segetane, ingenane, and jatrophane diterpenes from Euphorbia taurinensis. Planta Med. 84:729-35, 2018.

\section{IF: $\mathbf{2 . 7 4 6}$}

VI. Żesławska E, Kincses A, Unger V, Tóth V, Spengler G, Nitek W, Tejchman W. Exocyclic sulfur and selenoorganic compounds towards their anticancer effects and biological studies. Anticancer Res. 38: 4577-84, 2018.

\section{IF: 1.935}

VII. Nagyné-Kovács T, Studnicka L, Kincses A, Spengler G, Molnár M, Tolner M, Lukács IE, Szilágyi MI, Pokol Gy. Synthesis and characterization of Sr and $\mathrm{Mg}$ doped hydroxyapatite by a simple precipitation method. Ceramics Int. 44: 22976-82, 2018 .

\section{IF: 3.45}

VIII. Ferreira RJ, Kincses A, Gajdács M, Spengler G, Dos Santos DJVA, Molnár J, Ferreira MJU. Terpenoids from Euphorbia pedroi as multidrug-resistance reversers. J Nat Prod. 81: 2032-40, 2018.

\section{IF: 4.257}

IX. Spengler G, Kincses A, Rácz B, Varga B, Watanabe G, Saijo R, Sekiya H, Tamai E, Maki J, Molnár J, Kawase M. Benzoxazole-based Zn(II) and $\mathrm{Cu}$ (II) complexes overcome multidrug-resistance in cancer. Anticancer Res. 38: 6181-7, 2018.

\section{IF: 1.935}

X. Żesławska E, Kincses A, Spengler G, Nitek W, Tejchman W, Handzlik J. Pharmacophoric features for a very potent 5-spirofluorenehydantoin inhibitor of cancer efflux pump ABCB1, based on X-ray analysis. Chem Biol Drug Des. 93: 844$53,2019$.

IF: 2.256

XI. Nasim MJ, Witek K, Kincses A, Abdin AY, Żesławska E, Marć MA, Gajdács M, Spengler $\mathrm{G}$ et al. Pronounced activity of aromatic selenocyanates against multidrug resistant ESKAPE bacteria. New J. Chem. 43: 6021-31, 2019.

IF: 3.069 
XII. Mouwakeh A, Kincses A, Nové M, Mosolygó T, Mohácsi-Farkas C, Kiskó G, Spengler G. Nigella sativa essential oil and its bioactive compounds as resistance modifiers against Staphylococcus aureus. Phytother Res. 33: 1010-18, 2019.

IF: 3.766

XIII. Csonka A, Kincses A, Nové M, Vadas Zs, Sanmartín C, Domínguez-Álvarez E, Spengler G. Selenoesters and selenoanhydrides as novel agents against resistant breast cancer. Anticancer Res. 39: 3777-83, 2019.

\section{IF: 1.935}

XIV. Lentz F, Reiling N, Spengler G, Kincses A, Csonka A, Molnár J, Hilgeroth A. Dually acting nonclassical 1,4-dihydropyridines promote the anti-tuberculosis (Tb) activities of clofazimine. Molecules. 24: E2873, 2019.

IF: 3.06

XV. Mosolygó T, Mouwakeh A, Hussein Ali M, Kincses A, Mohácsi-Farkas Cs, Kiskó G, Spengler G. Bioactive compounds of Nigella sativa essential oils as antibacterial agents against Chlamydia trachomatis D. Microorganisms. 7: 370, 2019.

IF: 4.167

Total IF: 46.489

Cumulative IF: 54.268 


\section{ABBREVATIONS}

ABC ATP-binding cassette family

ABCB1 ATP-binding cassette subfamily B member 1

AGE aminoglycoside-modifying enzyme

AHL N-acyl-homoserine lactone

AI

autoinducer

AMR antimicrobial resistance

ATP adenosine triphosphate

CCCP carbonyl cyanide $m$-chlorophenyl hydrazone

CI combination index

CIP ciprofloxacin

CV crystal violet

DMSO dimethyl sulfoxide

DNA deoxyribonucleic acid

EB ethidium bromide

ED90 effective dose for $90 \%$ inhibition of bacterial growth

EP efflux pump

EPI efflux pump inhibitor

EPS extracellular polymeric substance

ESBL extended-spectrum- $\beta$-lactamase

HGT horizontal gene transfer

IM inner membrane

LB Luria-Bertani

MATE multidrug and toxic compound extrusion family

MDR multidrug resistant

MFS major facilitator superfamily

MH Mueller Hinton

MIC minimum inhibitory concentration

MRSA methicillin resistant Staphylococcus aureus

NBD nucleotide-binding domain

OD optical density

OM outer membrane 
PACE proteobacterial antimicrobial compound efflux family

PBS phosphate buffered saline

PMF proton motive force

PMZ promethazine

PPB potassium phosphate buffer

QS quorum sensing

RF relative fluorescence

RFI relative fluorescence index

RNA ribonucleic acid

RND resistance-nodulation-division family

RT-qPCR reverse transcriptase quantitative polymerase chain reaction

SMR small multidrug resistance family

TET tetracycline

TMD transmembrane domain

TSB tryptic soy broth 


\section{INTRODUCTION}

\section{Antimicrobial resistance}

In ancient cultures bacterial infections were treated using different materials such as animal faeces, herbs and honey and one of the greatest successes was the use of moldy bread. The beneficial effects of mold were also published in 1640 by John Parkinson. Besides organic compounds, in the ancient Asian and Mediterranean civilizations the antimicrobial properties of silver in wound care were known and applied ${ }^{1}$. In the $1600 \mathrm{~s}$ silver clips were used in surgery to prevent infection, then in the 1880 s silver nitrate solution was applied to the eyes of newborns to reduce the incidence of ophthalmia neonatorum ${ }^{2}$. A major break-through in the treatment of bacterial infections was the discovery of antibiotics. Penicillin was the first antibiotic discovered by Sir Alexander Fleming in 1928 and that became widespread in 1944. With the introduction of penicillin began the golden age of antibiotics. However, just a few new antibiotics had been discovered in recent decades (for example linezolid in 2000, daptomycin in 2013 and ceftaroline in 2010) ${ }^{3}$. The evolution of resistant pathogens and antimicrobial resistance (AMR) have begun to increase dramatically after the introduction of antibiotics ${ }^{4-6}$. AMR is the ability of a microorganism to survive treatment with an antibiotic or antimicrobial agent to which it was previously sensitive. The rapid spread of AMR is a consequence of the inappropriate use of antibiotics, in particular in medical practice, aquaculture, and agriculture ${ }^{7,8}$. Resistant bacteria are able to withstand the attack of antimicrobials, consequently the standard therapy becomes ineffective leading to increased treatment costs and may cause fatal outcomes ${ }^{9}$. The seriousness of AMR is corroborated by several facts: according to the report of The European Centre for Disease Prevention and Control (ECDC) Escherichia coli isolates resistant to aminopenicillins show an alarming tendency in Latvia: ratio of resistant isolates was $48.4 \%$ in 2014, and three years later was already $60.4 \%$. In contrast the number of invasive isolates of methicillin resistant Staphylococcus aureus (MRSA) experienced decreasing trend between 2014 (19.6\%) and $2017(16.9 \%)^{10}$. The O’Neill report estimates that by 205010 million lives and 100 trillion USD of economic output are at risk from $\mathrm{AMR}^{11}$.

Multidrug resistant (MDR) bacteria show resistance against at least three different classes of antibiotics that is also a serious problem for the treatment of bacterial infections ${ }^{3}$. In Europe, $28.4 \%$ of the Acinetobacter isolates were resistant to aminoglycosides, carbapenems and fluoroquinolones in 2017. Even challenging is the MDR Klebsiella 
pneumoniae in Europe whereas $15 \%$ of the total number of tested isolates were resistant to three antimicrobial groups ${ }^{10}$. One more fact from the United States of America: about 26,000 health-care acquired extended-spectrum- $\beta$-lactamase (ESBL)-producing Enterobacteriaceae infections result in 1,700 deaths every year ${ }^{12}$.

Bacteria have evolved different mechanisms to prevent the harmful effect of antibacterial drugs as a result of chromosomal mutations or horizontal gene transfer $(\mathrm{HGT})^{13}$. AMR may be acquired, adaptive or intrinsic ${ }^{14}$. Acquired resistance may develop through the following mechanisms: inactivation, increased efflux, reduced uptake and target alteration of antibiotics ${ }^{15,16}$. One of the most important resistance mechanisms is the presence of MDR efflux pumps (EPs). EPs can transport antimicrobial agents out of the bacterial cells ${ }^{17}$. Adaptive resistance means that bacteria are able to adapt to different

environmental conditions by differential gene expression pattern ${ }^{14}$. Examples of adaptive resistance are the persister cells that can change their metabolism, stop their growth and thus tolerate the antimicrobial treatments ${ }^{18}$. All Gram-negative bacteria have intrinsic resistance due to the outer membrane (OM) that is a permeability barrier and prevents the entrance of antibiotics $^{19}$.

The spread of AMR is a global challenge and to overcome this problem the combination therapy could be a solution (antibiotic plus adjuvants: for example EP inhibitor) in order to improve the efficacy of antibacterial therapy, prevent the emergence of MDR bacteria and decrease the costs of therapy ${ }^{20}$.

\section{Horizontal gene transfer mechanisms}

Emergence of AMR has become through the chromosomal mutations or the HGT between bacterial species ${ }^{21}$. In the course of HGT bacteria acquire genetic information (for example antibiotic resistance genes) from the environment by three canonical routes: transformation, transduction and conjugation (Figure 1) ${ }^{9,21,22}$. 


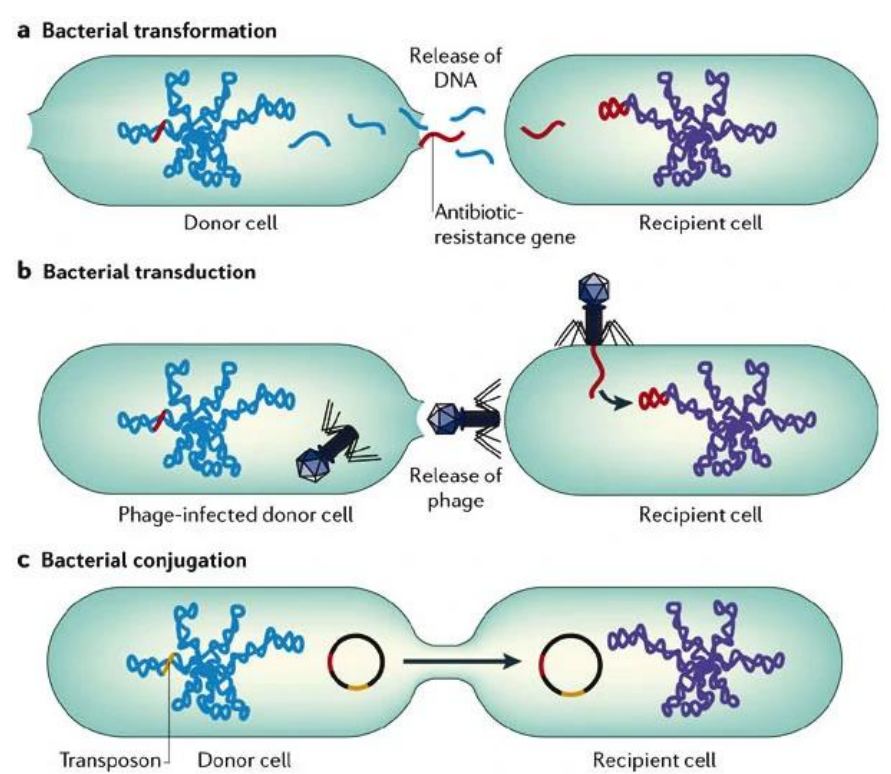

Figure 1 Mechanisms of horizontal gene transfer $(\mathrm{HGT})^{21}$

\section{Bacterial transformation}

Transformation means that the bacterium is able to be competent namely it is able to take up extracellular DNA from the environment and after that stably integrate it into its genome using homologous recombination ${ }^{23}$ or autonomously replicating element ${ }^{22-24}$. For example, Neisseria gonorrhoeae acquired penA (penicillin-binding protein 2) gene via transformation which is implicated in ceftriaxone resistance ${ }^{25}$.

\section{Bacterial transduction}

Through transduction bacteriophages can transfer DNA from phage-infected donor cell into a recipient bacterium during infection. After the infection, the transferable DNA can be integrated into the genome of the new host. The DNA sequence encapsulated in the virus particle may be chromosomal DNA molecules, plasmids, or large chromosomal regions such as genomic islands ${ }^{9,22,26}$. Colomer-Llunch and his co-workers found that mecA gene is present in bacteriophage from cattle farm slurry, furthermore pigs and poultry wastewater abattoir. In addition mecA gene plays a role in the dissemination of $\mathrm{MRSA}^{27}$.

\section{Bacterial conjugation}

Conjugation is the progress when DNA is transferred on plasmids from a donor cell to a recipient cell via a small tube namely pilus ${ }^{28}$. Conjugation is the most studied HGT process $^{29}$ and the most significant mechanism of AMR spreading ${ }^{30}$. Plasmids are responsible for the dissemination of ESBL ${ }^{31}$ and New Delhi metallo- $\beta$-lactamase producing bacteria ${ }^{32}$. 


\section{Mechanisms of acquired antimicrobial resistance}

Bacteria are able to become resistant to antibiotics by the following mechanisms: overexpression of EPs, antibiotic inactivation, modification of target molecule, and reduced influx of antibiotics (Figure 2) $16,33,34$.

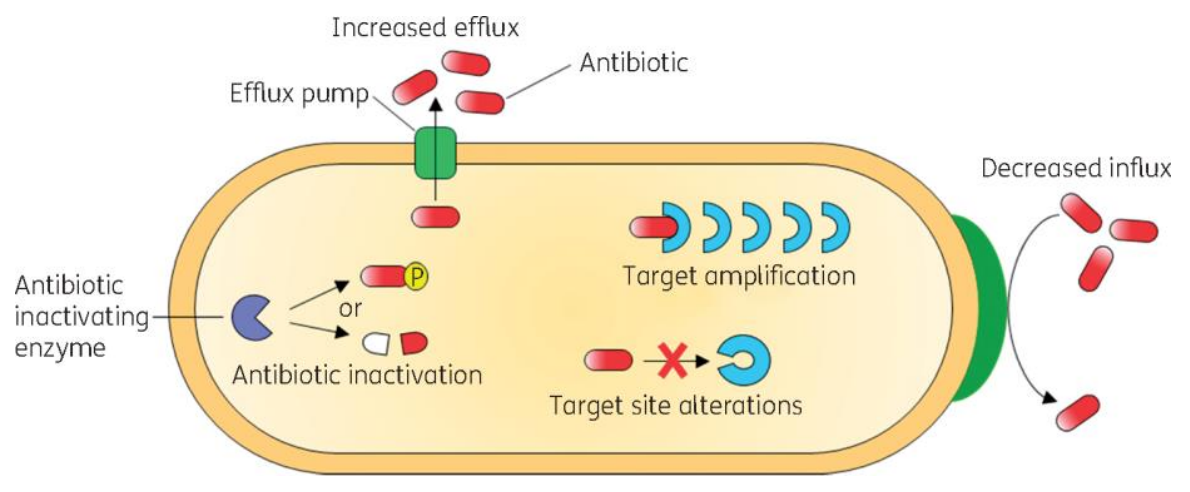

Figure 2 Mechanisms of antimicrobial resistance (AMR) in bacteria $^{35}$

\section{Over-expression of efflux pumps}

EPs are cytoplasmic membrane proteins which extrude various, structurally unrelated agents from the bacterial cell to the environment. EPs are found in Gram-negative and Gram-positive bacteria as well and these pumps contribute significantly to the development of AMR because they can be involved in intrinsic and acquired resistance, furthermore they can be responsible for transient, non-inheritable phenotypic resistance ${ }^{36}$.

\section{Antibiotic inactivation}

Bacteria can inactivate antibiotics by enzymes such as aminoglycoside-modifying enzymes (AGE's), $\beta$-lactamases and chloramphenicol acetyltransferases ${ }^{37}$. AGE's have already been described in Enterococcus faecalis, S. aureus and Streptococcus pneumoniae ${ }^{38}$, furthermore they can provide resistance to fluoroquinolones and aminoglycosides ${ }^{39}$. The members of $\beta$-lactamases (about 300) can develop AMR in Gram-negative bacteria by hydrolyzing $\beta$-lactam antibiotics ${ }^{40}$. Clinically, the most important enzymes are the ESBLs that can hydrolyze cephalosporins and penicillins in Enterobacteriaceae ${ }^{41}$. Furthermore, resistance enzymes are the chloramphenicol acetyltransferases found in some Gram-negative and Gram-positive strains. These enzymes acetylate the hydroxyl groups of chloramphenicol and as a result chloramphenicol is not able to bind to the 50S subunit of ribosome ${ }^{42}$.

\section{Modification of target molecule}

The antibiotics have targets and bind to them with high affinity, however if a spontaneous chromosomal mutation occurs in the target, the antibiotic is not able to bind ${ }^{37}$. 
One example is the methicillin and oxacillin resistance in $S$. aureus. If the mecA resistance gene is integrated into the chromosome of $S$. aureus, this gene codes a new penicillinbinding protein contributing to antibiotic resistance in this strain ${ }^{43}$.

\section{Reduced influx of antibiotics}

Gram-negative bacteria have selective diffusion barriers that reduce the penetration of the antibiotics into the cell, for example these barriers are the porins ${ }^{4-46}$ and the composition of cell wall (can be responsible for the lower penetration rate of antibiotics) ${ }^{47}$. The porins are located in the OM and through them the small hydrophilic drugs get into the cells. The permeability of molecules decreases with the number of porin channels ${ }^{37}$.

\section{Transporters in bacteria}

Transporter proteins are common in bacterial species and their normal physiological and protective function is to expel the noxious agents out of the cells ${ }^{48,49}$. Bacterial EPs are located in the cytoplasmic membrane ${ }^{50}$. One of the most important mechanisms of multidrug resistance is the over-expression of EPs which are able to export antimicrobials agents outside the bacterium before they reach their targets within the bacterial cell ${ }^{50}$. In bacteria six transporter families are distinguished: the ATP (adenosine triphosphate)-binding cassette (ABC) family, the multidrug and toxic compound extrusion (MATE) family, the major facilitator superfamily (MFS), the small multidrug resistance (SMR) family, the proteobacterial antimicrobial compound efflux (PACE) family, and the resistancenodulation-division (RND) family ${ }^{51-53}$. Based on their energy source transporters can be divided into two types: the primary EPs namely $\mathrm{ABC}$ transporters can bind and hydrolyze ATP to remove small molecules while the secondary EPs use electrochemical gradients namely proton motive force (PMF) or sodium ions to drive efflux (Figure 3$)^{36,54}$. The EPs are able to transport structurally unrelated molecules; they can drop one or more substrates to the environment of bacteria ${ }^{55}$. 


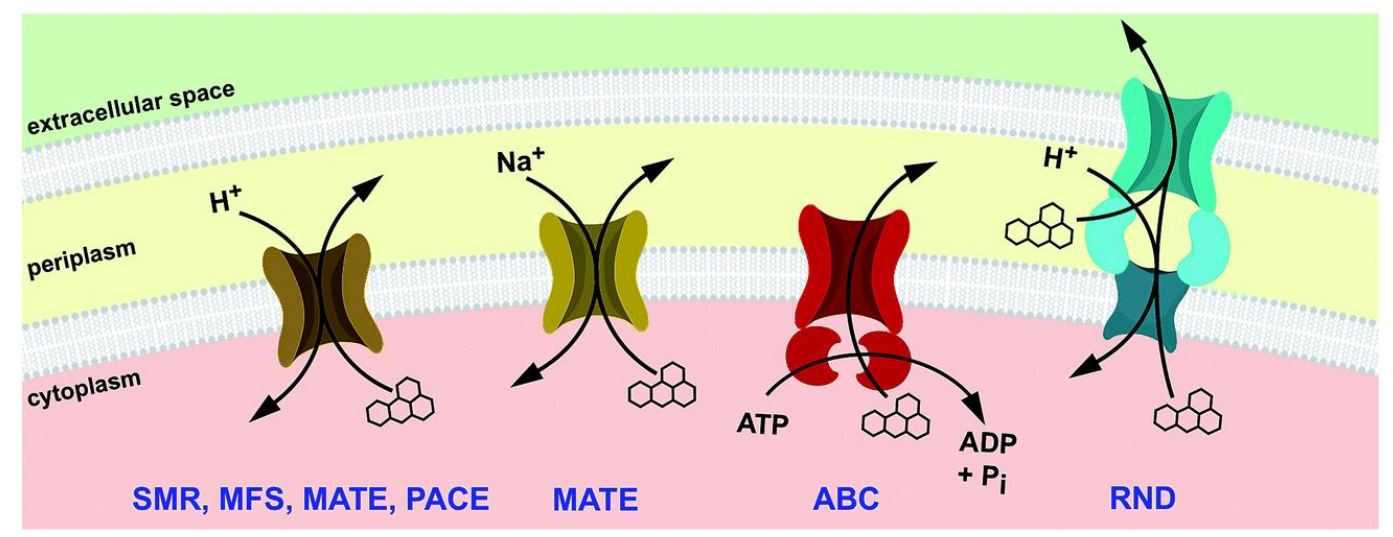

Figure 3 Schematic representation of transporter families based on energy sources used for export $^{55}$

\section{ABC transporters}

$\mathrm{ABC}$ transporters have been found in Gram-negative and Gram-positive bacteria ${ }^{56}$. It is the only transporter family that derives energy from ATP hydrolysis for the removal of substrates $^{52,57}$. These four partite EPs consists of two nucleotide-binding domains (NBDs) and two transmembrane domains (TMDs). NBDs are able to bind and hydrolize ATP. The function of TMDs is the recognition and export of wide range of compounds ${ }^{58-60}$. EfrAB from E. faecalis displays resistance to norfloxacin, ciprofloxacin (CIP) and doxycycline ${ }^{61}$. Additional ABC pumps have been described in the literature such as MacB from E. coli ${ }^{62}$, PatAB from S. pneumoniae ${ }^{63}$, and LmrA from Lactococcus lactis $^{64}$.

\section{MATE transporters}

The EPs of the MATE family are present in both Gram-negative and Gram-positive bacteria. MATE transporters comprise $12 \alpha$-helix transmembrane regions. MATE family members use the PMF $\left(\mathrm{H}^{+}\right)$and the sodium ion $\left(\mathrm{Na}^{+}\right)$gradient to extrude noxious compounds ${ }^{65}$. MATE pumps are capable of transporting a wide group of substrates as ethidium bromide (EB), metformin, cimetidine and the following antibiotics: norfloxacin, CIP, kanamycin, ampicillin, among others ${ }^{66}$. Multidrug EP members of the MATE include NorM from Vibrio parahaemolyticus ${ }^{67}$, YdhE from E. coli ${ }^{68}$, HmrM from Haemophilus influenzae $^{69}$, PmpM from Pseudomonas aeruginosa ${ }^{70}$ and MepA from S. aureus ${ }^{71}$.

\section{MFS transporters}

The members of MFS are widespread in both Gram-positive and Gram-negative bacteria. These proteins use the PMF in order to transport diverse substrates such as ions, sugars, Krebs-cycle intermediates as well as tetracycline (TET) and fluoroquinolones ${ }^{72,73}$. 
The MFS superfamily contains 12 or 14 transmembrane helices ${ }^{74}$. The EmrAB-TolC tripartite $\mathrm{EP}^{75}, \mathrm{EmrD}^{76}$ and MdfA from E. coli are structurally characterized. MdfA promotes the efflux of CIP, chloramphenicol and erythromycin ${ }^{77,78}$. Other members of this family are NorA ${ }^{79}$, QacA, $\mathrm{QacB}^{80}$ and $\mathrm{LmrS}^{81}$ of $S$. aureus, $\mathrm{LmrP}^{82}$ of L. lactis, $\mathrm{PmrA}^{83}$ of $S$. pneumoniae.

\section{SMR transporters}

SMR family is found in both Gram-positive and Gram-negative bacteria and these proteins are the smallest known transporters. SMR transporters have a predicted function as homodimers that contain 4 transmembrane helices. The efflux of noxious agents is mediated by the $\mathrm{PMF}^{57,65}$. One of the best studied pump is $\mathrm{EmrE}^{84}$ from E. coli that is able to extrude streptomycin, tobramycin ${ }^{85}$, erythromycin and $\mathrm{TET}^{86}$. Other representatives of SMR family: EbrAB $^{87}$ from Bacillus subtilis, QacC ${ }^{88}$ from S. aureus, YnfA ${ }^{89}$ from E. coli.

\section{PACE transporters}

PACE is the newest family of bacterial transporters, which has been described in Gram-negative bacteria. It has 4 transmembrane helices based on its predicted topology. The transporter AceI is the prototype protein from Acinetobacter baumannii and the homologue of this transporter has been found in the genomes of Burkholderia, Enterobacter, Klebsiella, Pseudomonas and Salmonella species. AceI and its homologues can mediate extrusion of chlorhexidine, benzalkonium, acriflavine and proflavine ${ }^{53,90}$.

\section{RND transporters}

RND transporters are widely distributed and they form a tripartite efflux system from the inner membrane (IM) to OM in Gram-negative bacteria ${ }^{91}$. The family uses PMF to accelerate the extrusion of broad range of antibiotics and biocides ${ }^{92}$. In Gram-positive bacteria (S. aureus, B. subtilis, Corynebacterium glutamicum and Clostridium difficile) only a few RND pump monomers have been described ${ }^{54,93,94}$. The most well characterized RND pump is the AcrAB-TolC multidrug transporter that consists of an IM transporter AcrB, a periplasmic adaptor protein AcrA and an OM channel called TolC (Figure 4) ${ }^{95,96}$. The AcrB EP consists of 12 transmembrane $\alpha$-helices ${ }^{97}$. 
AcrZ is 49 amino-acid length IM protein that associates with the AcrAB-TolC system: it is directly bound to the AcrB in order to regulate the substrate specificity of $\mathrm{AcrB}^{98}$. The hexamer protein AcrA stabilizes the assembly of the pump and the homotrimer TolC provides a channel to expel the substrates from bacteria to the milieu ${ }^{99,100}$. The system can transport EB, crystal violet (CV), erythromycin, fusidic acid, novobiocin, fluoroquinolones, macrolides, chloramphenicol, TET, rifampicin; detergents such as bile salts and disinfectants ${ }^{101,102}$. Other RND drug transporters have been discovered such as MexAB-OprM ${ }^{103}$, MexD, MexF and MexY $\mathrm{Y}^{104}$ from $P$. aeruginosa, $\mathrm{AcrD}^{105}$ from E. coli, $\mathrm{KexD}^{106}$ from K. pneumoniae and $\mathrm{MtrD}^{107}$ from N. gonorrhoeae.

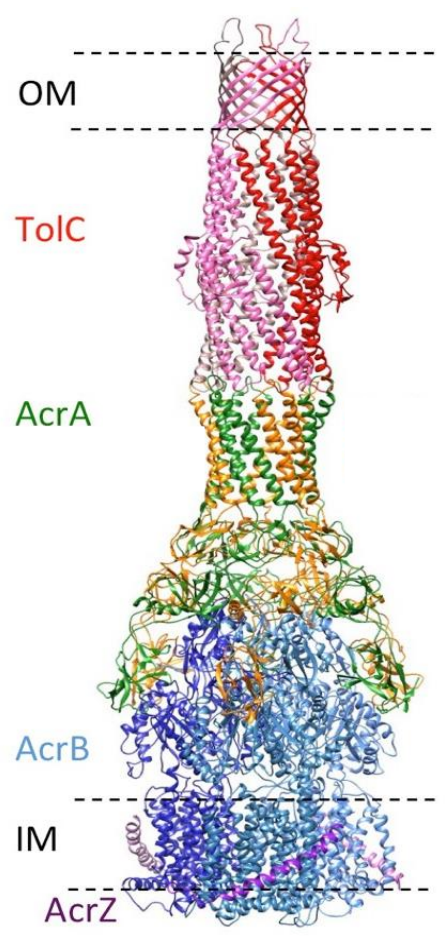

Figure 4 Structure of the AcrAB-TolC complex ${ }^{108}$

\section{Biofilm formation and quorum sensing}

Bacterial biofilm is a microbial community consisting of sessile bacterial cells attached to each other and to a surface and is embedded in a self-produced extracellular matrix ${ }^{109}$. Bacteria have the ability to form biofilms on both biotic (epithelial cells, tooth enamel etc.) and abiotic (plastic, glass, medical devices such as pacemakers, implants, catheters etc.) surfaces ${ }^{110,111}$. Biofilm-associated bacteria cause numerous infections, including endocarditis, urinary tract infections, periodontitis and nosocomial infections ${ }^{112}$. Biofilm formation has five stages: attachment, microcolonies and early biofilm formation, maturation and dispersion (Figure 5) ${ }^{113}$. In the first stage the planktonic cells attach to the surface. At the beginning, this attachment is initial and reversible and later becomes irreversible by flagella, pili, curli, and fimbriae ${ }^{114}$. After adherence, the bacterial cells proliferate and form a microcolony. The cells begin to grow and mature when these commence to synthesize extracellular polymeric substance (EPS) matrix ${ }^{113}$, which includes exopolysaccharides, proteins, nucleic acids ${ }^{115}$ and serves as a protective and diffusion barrier against antimicrobial agents. When conditions become unfavorable (lack of nutrients, competition, number of the bacterial population), a part of the biofilm will disperse and planktonic cells will be released from the biofilm so they can colonize other surfaces ${ }^{116}$. 


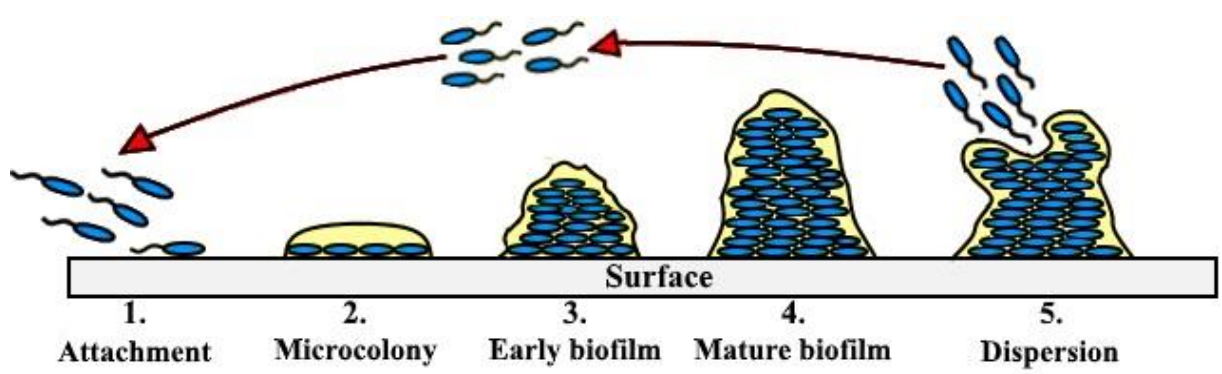

Figure 5 Schematic representation for the main stages of biofilm formation ${ }^{117}$

In the biofilm bacterial cells adapt to environmental conditions and bacteria show increased (about 10-1000 times) resistance against antimicrobial agents compared to planktonic bacteria $^{118}$. Some factors play a role in the AMR of biofilm such as poor penetration of the antibiotic due to the EPS ${ }^{119}$, slow growth and metabolism of biofilm cells $^{120}$, furthermore the transfer of AMR genes by conjugation is higher in biofilms ${ }^{121}$. Another reason is the presence of EPs. In some bacterial strains, EP genes are up-regulated showing that they contribute to biofilm formation ${ }^{35}$ and reduce susceptibility of the biofilm $^{122}$. EPs during biofilm formation extrude EPS and quorum sensing (QS) molecules. Transporters influence genes important for biofilm formation indirectly, furthermore they can pump out antibiotics and intermediates of metabolism ${ }^{35}$.

The expression of the genes required for biofilm formation have to be coordinated and bacteria achieve this using the QS signal-response process. In bacteria the QS is a cell-to-cell communication and regulatory mechanism that controls gene expression depending on bacterial cell density ${ }^{123-125}$. For example, Gram-negative bacteria synthesize the extracellular signaling molecules namely autoinducers (AIs) like N-acyl-homoserine lactone (AHL) by Lux-I-type synthase enzymes. In the next step AHLs diffuse or are transported into the environment to bind to their LuxR-type receptors (transcriptional regulator) in other nearby cells. The AI and regulator complex binds to DNA to influence the expression of target genes $^{126}$.

In E. coli $\mathrm{SdiA}$ is a LuxR homolog that detects AHL signals from other bacteria and has a great impact on the colonization of $E$. coli. SdiA represses the expression of virulence genes by interacting with unknown stationary-phase signals in E. coli $\mathrm{O} 157: \mathrm{H} 7^{127}$, and enhances multidrug resistance by activating MDR EPs in E. coli ${ }^{109}$.

\section{Background of resistance modulators applied in this study}

Resistance to antibiotics has become a serious problem in the treatment of infectious diseases because of the rapid spread of AMR. Consequently, there is a need to develop 
alternative compounds that may be useful alone or in combination therapy ${ }^{129}$. The discovery of plant-derived antimicrobials is advantageous because these plants are widely distributed in nature ${ }^{130}$ and they could be used in order to overcome drug resistance in bacteria by blocking QS, biofilm formation ${ }^{131}$ and multidrug $\mathrm{EPs}^{132}$. There are several studies in the literature providing evidence of the EP inhibitory potential of plant-derived compounds. It has been described that reserpine from the roots of Rauwolfia serpentina and $R$. vomitoria inhibits TET efflux by Bmr transporter of B. subtilis ${ }^{133}$. Piperine isolated from black pepper (Piper nigrum) has been identified as an inhibitor of NorA pump of MRSA ${ }^{134}$. Falcarindiol, linoleic and oleic acids of Levisticum officinale reduce the efflux of AcrAB-TolC EP of Salmonella enterica serovar Typhimurium ${ }^{135}$. Nigella sativa essential oil has shown activity against the EP systems of methicillin sensitive $S$. aureus and MRSA strains ${ }^{136}$. Cleistochlamys kirkii (Benth) Oliv. (Annonaceae) is an African medicinal plant traditionally used in Mozambique for the treatment of wound infections, tuberculosis and rheumatism ${ }^{137}$. Based on preliminary studies $C$. kirkii derivatives have a broad antimicrobial spectrum: they had antifungal activity against Candida albicans and exhibited antibacterial effect against methicillin sensitive $S$. aureus and MRSA ${ }^{138,139}$.

Organic compounds of phosphorus ylides (P-ylides) are a fascinating class of compounds in organic chemistry ${ }^{140}$. The EP modulating activity of P-ylides has already been described regarding the ATP-binding cassette subfamily B member (ABCB1) pump of MDR mouse T-lymphoma cells ${ }^{141}$ and the further biological aspects of the phosphorus ylides in bacteria have not been yet investigated in the literature.

Selenium is an important trace element, which plays a role in the prevention of inflammatory diseases and cancer ${ }^{142}$. The antibacterial activity of selenium-containing compounds has been found by many studies: research was mostly done using bacteria that cause nosocomial infections. E. coli $^{143}$ and S. aureus ${ }^{144}$ are often responsible for infections during hospitalization ${ }^{145}$. Infections caused by these bacteria are difficult to treat due to their biofilm forming ability. It has been demonstrated by a research group that a perihydroselenoxantine compound showed antibacterial activity on $S$. aureus $\operatorname{strain}^{146}$. Sodium selenite has been found to eradicate Helicobacter pylori and it showed antibacterial effect against $H$. pylori at a low concentration in rats ${ }^{147}$. In another study, three polymers (polyvinyl chloride, polyurethane and silicone) were coated with selenium nanoparticles. The growth of $S$. aureus was prevented on selenium-coated polymers compared to the uncoated materials $^{148}$. The novel selenocompounds tested in this study have been previously described as anticancer compounds against T-lymphoma and colon cancer cell lines ${ }^{149,150}$. 


\begin{abstract}
AIMS OF THE STUDY
Resistant bacteria are able to withstand the attack of antimicrobials, so that standard treatments become ineffective and infections persist and may spread to others. Efflux mechanisms of bacteria, namely, pumping of antimicrobial agents out of the cells play an important role in antimicrobial resistance of pathogenic bacteria. The aim of our study was to investigate the bioactive compounds of Cleistochlamys kirkii, synthesized fluorinated $\beta$ diketo phosphorus ylides and selenocompounds on Gram-positive and Gram-negative model bacterial strains in order to find resistance modifiers which could be applied later alone or in combination with antibiotics.
\end{abstract}

The main goals of the study were the following:

1. Determination of the antibacterial activity of the compounds (five natural compounds, ten fluorinated $\beta$-diketo phosphorus ylides and eleven selenocompounds) on Gram-positive (Enterococcus faecalis ATCC 29212, Staphylococcus aureus ATCC 25923, S. aureus 272123) and Gram-negative strains (Escherichia coli AG100, AG100 A, Salmonella enterica serovar Typhimurium SL1344 (wild-type), L644 ( $\Delta$ acrB strain), 14028s (biofilm producing strain), Chromobacterium violaceum 026 and Enterobacter cloacae 31298 by microdilution method.

2. Investigation of the efflux pump (EP) inhibitory effect of the compounds (five natural compounds, ten fluorinated $\beta$-diketo phosphorus ylides and eleven selenocompounds) on Gram-positive (S. aureus ATCC 25923, S. aureus 272123) and Gram-negative strains (E. coli AG100 expressing the AcrAB-TolC EP and its AcrAB-TolC deleted mutant AG100 A strain) using real-time ethidium bromide (EB) accumulation assay.

3. Evaluation of the EP inhibitory effect of eleven selenocompounds on Gramnegative wild-type $S$. Typhimurium SL1344 strain expressing the AcrAB-TolC EP and its AcrB deleted mutant L644 strain using EB efflux assay.

4. Determination of the anti-biofilm activity of eleven selenocompounds on Gramnegative, biofilm producing $S$. Typhimurium 14028 s strain using crystal violet (CV). 
5. Characterization of the activity of five natural compounds of $C$. kirkii as adjuvants in the presence of tetracycline (TET) and ciprofloxacin (CIP) on S. aureus ATCC 25923 and S. aureus 27213 strains by checkerboard method.

6. Evaluation of the adjuvant role of eleven selenocompounds on E. coli AG100 strain by a two-fold broth microdilution method in the presence of TET and CIP.

7. Quorum sensing (QS) inhibition analysis of five natural compounds of C. kirkii and ten fluorinated $\boldsymbol{\beta}$-diketo phosphorus ylides using the sensor strain $C$. violaceum 026 and the AHL producer strain E. cloacae 31298 by agar diffusion method.

8. Monitoring the changes in relative gene expression of efflux (norA, mepA, acrA, $a c r B)$, antibiotic resistance (marR) and QS ( $s d i A)$ genes in the presence of the most effective EP inhibitors (natural compounds isolated from $C$. kirkii, fluorinated $\beta$ diketo phosphorus ylides and selenocompounds) investigated by reverse transcriptase quantitative polymerase chain reaction (RT-qPCR). 


\section{MATERIALS AND METHODS}

\section{Compounds studied}

Five natural compounds (CK1-5) were isolated from the methanol extract of the root barks of Cleistochlamys kirkii (Benth.) Oliv. (Annonaceae): triterpene polycarpol (CK1), Cbenzylated flavanones chamanetin (CK2), isochamanetin (CK3), dichamanetin (CK4) and the heptane derivative acetylmelodorinol (CK5) were kindly provided by Prof. Dr. MariaJosé U. Ferreira (Universidade de Lisboa, Lisbon, Portugal; Figure 6). The stock solutions (in $10 \mathrm{mM}$ concentration) of compounds were prepared in dimethyl sulfoxide (DMSO).
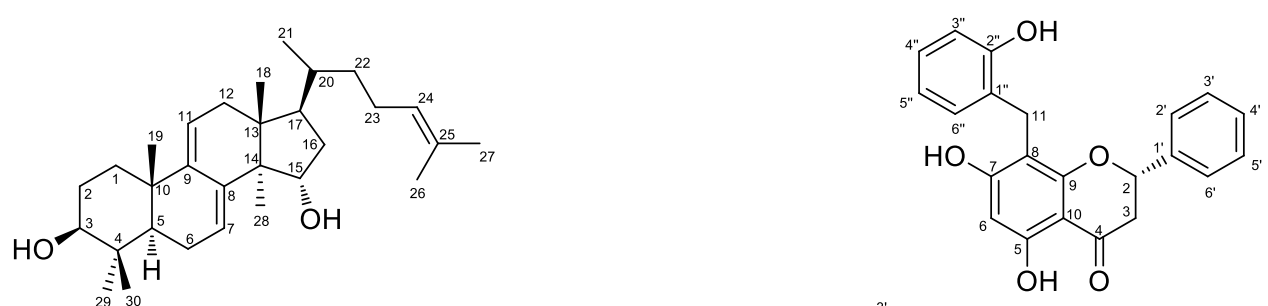

Polycarpol (1)<smiles></smiles>

Chamanetin (2)

Isochamanetin (3)<smiles>O=C1C[C@@H](c2ccccc2)Oc2c(Cc3ccccc3O)c(O)c(Cc3ccccc3O)c(O)c21</smiles><smiles>CC(=O)O[C@H](C=C1C=CC(=O)O1)COC(=O)c1ccccc1</smiles>

Acetylmelodorinol (5)

Figure 6 Chemical structures of bioactive compounds (CK1-5)

Ten synthesized fluorinated $\beta$-diketo phosphorus ylides (P-ylides; PY1-10) were kindly provided by Prof. Dr. Masami Kawase (Matsuyama University, Matsuyama, Japan) (See Appendix 1 and 2). The stock solutions (in $10 \mathrm{mg} / \mathrm{mL}$ concentration) of compounds were prepared in DMSO.

Eleven selenocompounds including a cyclic selenoanhydride (EDA1), heteroaryl selenoesters (EDA2-3) and aryl selenoesters (EDA4-11) were kindly provided by Dr. Enrique Domínguez-Álvarez (Consejo Superior de Investigaciones Científicas, Madrid, Spain) and Prof. Dr. Carmen Sanmartín (University of Navarra, Pamplona, Spain) ${ }^{149,151}$ 
(Figure 7; See Appendix 3 and 4). The stock solutions (in $10 \mathrm{mM}$ concentration) of compounds were prepared in DMSO.<smiles>O=C1[Se]C(=O)c2ccccc21</smiles>

A<smiles>[R]c1cccc(C(=O)[Se]C)c1</smiles>

B<smiles>[R][Se]C(=O)c1ccc([R])cc1</smiles>

$\mathrm{C}$

Figure 7 Chemical structures of tested selenoanhydride (EDA1) (A), heteroaryl selenoesters (EDA2-3) (B) and aryl selenoesters (EDA4-11) (C)

\section{Reagents and media}

Promethazine (PMZ; EGIS), ethidium bromide (EB), carbonyl cyanide $m$ chlorophenyl hydrazone (CCCP), verapamil, crystal violet $(\mathrm{CV})$, tetracycline-hydrochloride (TET), ciprofloxacin-hydrochloride (CIP), DMSO, Luria-Bertani (LB) broth, and LB agar were purchased from Sigma-Aldrich Chemie GmbH (Steinheim, Germany). The modified LB medium (LB*) was prepared from yeast extract $5 \mathrm{~g} / \mathrm{L}$, tryptone $10 \mathrm{~g} / \mathrm{L}, \mathrm{NaCl} 10 \mathrm{~g} / \mathrm{L}$, $\mathrm{K}_{2} \mathrm{HPO}_{4} 1 \mathrm{~g} / \mathrm{L}, \mathrm{MgSO}_{4} \times \mathrm{H}_{2} \mathrm{O} 0.3 \mathrm{~g} / \mathrm{L}$ and FeNaEDTA $36 \mathrm{mg} / \mathrm{L}$. In case of modified LB* agar, the LB* medium was supplemented with agar $20 \mathrm{~g} / \mathrm{L}$ (Difco, Detroit, USA). pH was adjusted to 7.2. Tryptic soy broth (TSB), tryptic soy agar (TSA), and Mueller Hinton (MH) broth were purchased from Scharlau Chemie S. A. (Barcelona, Spain).

\section{Bacterial strains}

Wild-type Escherichia coli K-12 AG100 strain [argE3 thi-1 rpsL xyl mtl $\Delta$ (gal-uvrB) supE44], expressing the AcrAB-TolC efflux pump (EP) at its basal level and its AcrAB-TolC deleted mutant E. coli AG100 A strain were used in the study. These strains were kindly provided by Prof. Dr. Hiroshi Nikaido (University of California, Berkeley, CA, USA).

Wild-type Salmonella enterica serovar Typhimurium SL1344 expressing the AcrABTolC EP and its $a c r B$ gene inactivated mutant $S$. Typhimurium strain (L644) ${ }^{152}$, furthermore, the biofilm producing $S$. Typhimurium 14028s strain were used in the study. These strains were kindly provided by Dr. Jessica M. A. Blair (University of Birmingham, Birmingham, United Kingdom). 
Staphylococcus aureus ATCC (American Type Culture Collection) 25923, was used as the methicillin susceptible reference strain, and the methicillin and ofloxacin resistant $S$. aureus 272123 clinical isolate was kindly provided by Prof. Dr. Leonard Amaral (Institute of Hygiene and Tropical Medicine, Lisbon, Portugal). In addition, Enterococcus faecalis ATCC 29212 strain was used in the assays.

For quorum sensing (QS) tests, the following strains were used: Chromobacterium violaceum 026 (CV026) as sensor strain and Enterobacter cloacae 31298 as N-acylhomoserine lactone (AHL) producer strain (a clinical isolate from a wound) ${ }^{153}$.

\section{Determination of minimum inhibitory concentrations by microdilution method}

The minimum inhibitory concentrations (MICs) of all tested compounds were determined according to the Clinical and Laboratory Standards Institute (CLSI) guidelines in three independent assays ${ }^{154}$. The solvent DMSO had no antibacterial effect.

\section{Real-time accumulation assay of ethidium bromide}

The activity of compounds isolated from C. kirkii (CK1-5), P-ylides (PY1-10) and selenocompounds (EDA1-11) on the real-time accumulation of EB was assessed by the automated EB method ${ }^{155}$ using a LightCycler real-time thermocycler (LightCycler 1.5, Roche, Indianapolis, USA). Briefly, an aliquot of an overnight culture of S. aureus strains (ATCC 25923 and MRSA 272123) in TSB medium was transferred to fresh TSB medium, and it was incubated until it reached an optical density (OD) of 0.6 at $600 \mathrm{~nm}$. In case of $E$. coli AG100 and AG100 A, the medium used in the assay was LB broth; the preparation of the inoculum was similar to the one of $S$. aureus. The cells were washed with phosphate buffered saline (PBS; pH 7.4) and centrifuged at 13,000 $\times g$ for 3 minutes, the pellets were re-suspended in PBS (pH 7.4), and the OD was adjusted to 0.6 at $600 \mathrm{~nm}$. The compounds were added individually at different concentrations at $1 / 2 \mathrm{MIC}, 1 / 3 \mathrm{MIC}, 1 / 4 \mathrm{MIC}$ or $1 / 5 \mathrm{MIC}$ (in double concentrated form) to the EB solution in PBS. The final concentration of EB was based on the MIC and the lowest fluorescent signal produced by this sub-MIC concentration of EB. In case of $S$. aureus strains, the concentration of $\mathrm{EB}$ was $0.5 \mu \mathrm{g} / \mathrm{mL}$, for $E$. coli AG100 $1 \mu \mathrm{g} / \mathrm{mL}$, and in case of E. coli AG100 A it was $0.25 \mu \mathrm{g} / \mathrm{mL}$. Then, $10 \mu \mathrm{L}$ of the EB solution containing the compound were transferred into standard glass capillary tubes of 20 $\mu \mathrm{L}$ maximum volume (Roche, Indianapolis, IN, USA), and $10 \mu \mathrm{L}$ of bacterial suspension (OD of 0.6 at $600 \mathrm{~nm}$ ) were added to the capillaries. The capillaries containing the samples were placed into the carousel (Roche), and the fluorescence was monitored at the FL-2 channel in every minute on a real-time basis. 
From the real-time data, the activity of the compounds, namely the relative fluorescence index (RFI) of the last time point (minute 30) of the EB accumulation assay, was calculated according to the following formula:

$$
R F I=\frac{R F_{\text {treated }}-R F_{\text {untreated }}}{R F_{\text {untreated }}}
$$

Where $\mathrm{RF}_{\text {treated }}$ is the relative fluorescence $(\mathrm{RF})$ at the last time point of $\mathrm{EB}$ retention curve in the presence of an inhibitor, and $\mathrm{RF}_{\text {untreated }}$ is the $\mathrm{RF}$ at the last time point of the $\mathrm{EB}$ retention curve of the untreated control having the solvent control (DMSO). Verapamil was applied as a positive control on Gram-positive strains and PMZ was used on Gram-negative strains.

\section{Efflux assay using ethidium bromide}

The activity of selenocompounds (EDA1-11) on the efflux of EB was determined on wild-type (SL1344) and $a c r B$ gene inactivated (L644) S. Typhimurium strains. Briefly, an aliquot of an overnight culture of $S$. Typhimurium strain in LB medium was transferred to fresh LB medium, and it was incubated at $37^{\circ} \mathrm{C}$ with shaking at $150 \mathrm{rpm}$ until it reached an OD of 0.4 at $600 \mathrm{~nm}$. The cultures were centrifuged at $3500 \mathrm{rpm}$ for $10 \mathrm{~min}$ at $21^{\circ} \mathrm{C}$. The supernatant was removed, and the pellet was re-suspended in $20 \mathrm{mM}$ potassium phosphate buffer (PPB; pH 7.0) with $1 \mathrm{mM} \mathrm{MgCl}_{2}$ and the OD was adjusted to 0.2 at $600 \mathrm{~nm} .100 \mu \mathrm{M}$ of $\mathrm{CCCP}$ was added to de-energize the cells and therefore $\mathrm{EB}$ was added at $50 \mu \mathrm{g} / \mathrm{mL}$ concentration. The cultures were incubated at $23^{\circ} \mathrm{C}$ with shaking at $150 \mathrm{rpm}$ for $1 \mathrm{~h}$. After the incubation period the cultures were centrifuged at $3500 \mathrm{rpm}$ for $10 \mathrm{~min}$ at $21^{\circ} \mathrm{C}$. The supernatant was decanted, and the pellet was re-suspended in $20 \mathrm{mM}$ PPB buffer ( $\mathrm{pH} 7.0$ ) with $1 \mathrm{mM} \mathrm{MgCl} 2$ and $5 \%$ glucose to energize the cells. Following energization, $200 \mu \mathrm{L}$ of the bacterial culture were transferred into black 96-well microtiter plate (Corning, Amsterdam) containing the compounds at $50 \mu \mathrm{M}(1 / 2 \mathrm{MIC})$ and the fluorescence of EB was measured over 2 hours at excitation and emission wavelengths of 530 and $600 \mathrm{~nm}$, respectively, using a FLUOstar Optima plate reader (BMG Labtech, United Kingdom) ${ }^{152}$. During the evaluation the exact time was determined when the fluorescence dropped by $25 \%$ and $50 \%$ of the starting value. CCCP was applied as a positive control and DMSO was used as a negative control. 


\section{Measuring biofilm formation using crystal violet}

The biofilm forming ability of $S$. Typhimurium 14028s strain was studied in 96-well microtiter plates using LB broth without salt in the presence of selenocompounds (EDA111). Initially, overnight cultures were diluted to an OD of 0.1 at $600 \mathrm{~nm}$ and then added to each well with the exception of the medium control wells and compounds were added at 50 $\mu \mathrm{M}(1 / 2 \mathrm{MIC})$ concentration. The final volume was $200 \mu \mathrm{L}$ in each well. Plates were incubated at $30^{\circ} \mathrm{C}$ for $48 \mathrm{~h}$ with gentle agitation $(100 \mathrm{rpm})$. After the incubation period the medium was discarded, and the plate was washed with tap water to remove unattached cells. $200 \mu \mathrm{L} \mathrm{CV}(0.1 \%[\mathrm{v} / \mathrm{v}])$ was added to the wells and incubated for 15 minutes at room temperature. $\mathrm{CV}$ was removed from the wells and the plate was washed again with tap water. $200 \mu \mathrm{L}$ of $70 \%$ ethanol was added to each well and the biofilm formation was determined by measuring the OD at $600 \mathrm{~nm}$ using a FLUOstar Optima plate reader. The anti-biofilm effect of selenocompounds was expressed in the percentage (\%) of decrease in biofilm formation. The results were analyzed using t-test and $p$-values of $<0.05$ were considered significant.

\section{Interaction between antibiotics and resistance modifiers using checkerboard method}

The combined effect of chamanetin (CK2) and dichamanetin (CK4) and antibiotics on the growth inhibition of S. aureus ATCC 25923 and methicillin resistant S. aureus 272123 strains was evaluated by checkerboard method. Two-fold serial dilutions of antibiotics were prepared in $\mathrm{MH}$ broth on the horizontal rows of microtiter plate and then cross-diluted vertically by two-fold serial dilutions of the compounds ${ }^{156}$. For this assay, only the compounds with well-defined MIC values could be used. The dilutions of the antibiotics (TET or CIP) were made in a horizontal direction in $100 \mu \mathrm{L}$, and the dilutions of compounds were made vertically in the microtiter plate in $50 \mu \mathrm{L}$. After the dilution of an overnight culture, bacterial cells were re-suspended in $\mathrm{MH}$ medium containing $1 \times 10^{4}$ cells and distributed into each well. The plates were incubated for $18 \mathrm{~h}$ at $37^{\circ} \mathrm{C}$. The cell growth rate was determined after MTT (3-(4,5-dimethylthiazol-2-yl)-2,5-diphenyltetrazolium bromide) staining (See Appendix 5), as described elsewhere (Figure 8) ${ }^{156}$. The combination index (CI) values at $90 \%$ growth inhibition $\left(\mathrm{ED}_{90}\right)$ were determined by CompuSyn software to plot 4 or 5 data points for each ratio (www.combosyn.com, ComboSyn, Inc., Paramus, NJ. 07652 USA). CI values were calculated by means of the median-effect equation, where $\mathrm{CI}<1, \mathrm{CI}=$ 1 and CI > 1 represent synergism, an additive effect (or no interaction) and antagonism, respectively ${ }^{157}$. 


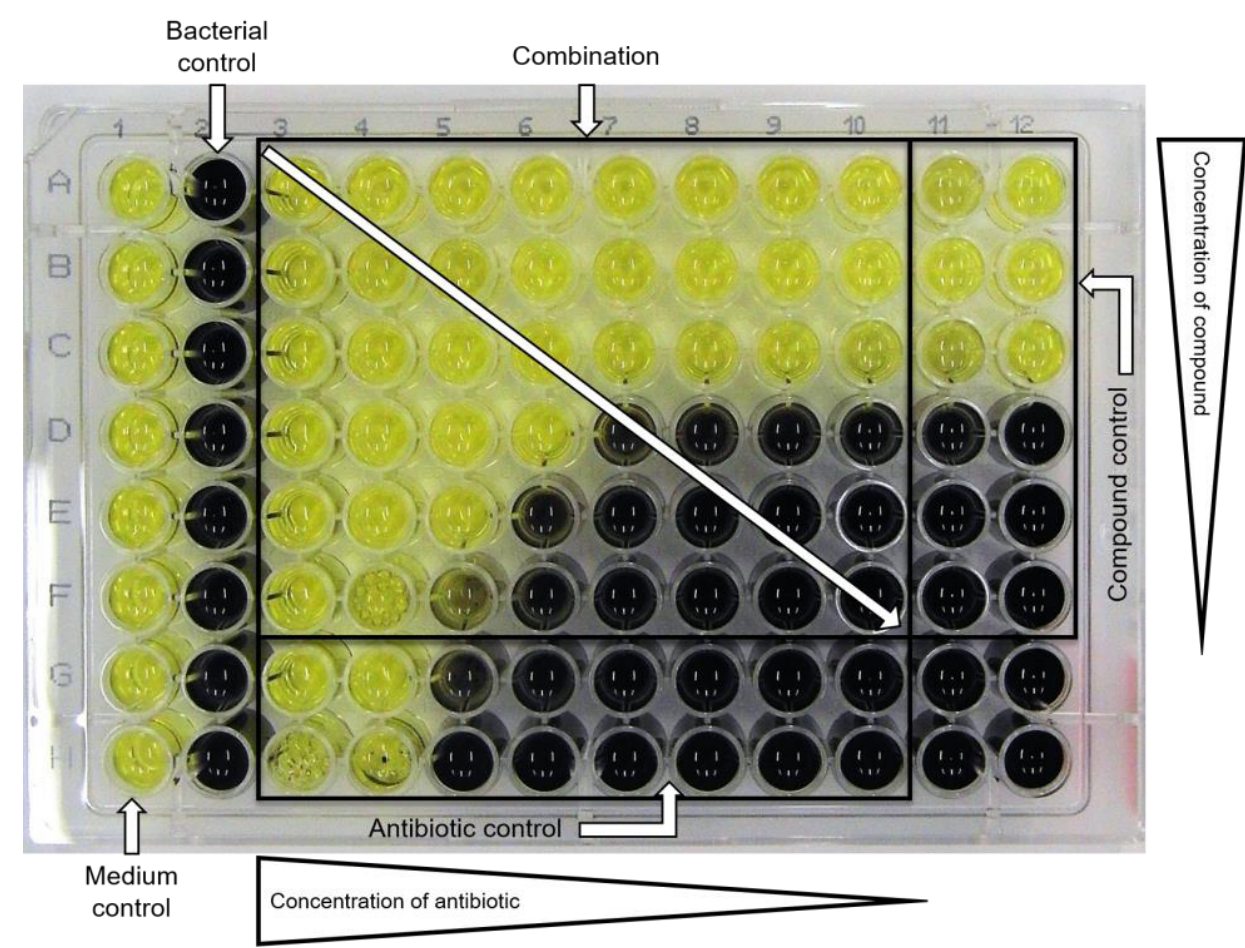

Figure $\mathbf{8}$ The layout of checkerboard plates

\section{Interaction between antibiotics and resistance modifiers using minimum inhibitory concentration reduction assay}

The chemosensitizing effect of the selenocompounds (EDA1-11) was evaluated by the determination of the MIC values of the antibiotics (TET and CIP), in the presence of subinhibitory concentrations of the compounds ( $1 / 2$ MIC) in E. coli AG100 strain by a two-fold broth microdilution method in the 96-well plates, using serial dilutions of TET and CIP. The first four rows contained two-fold dilutions of antibiotics, and the combinations of the antibiotics and tested compounds were added into the last four rows. $10^{-4}$ dilution of an overnight bacterial culture in $50 \mu \mathrm{L}$ of $\mathrm{MH}$ was then added to each well, with the exception of the medium control wells. The plates were then incubated at $37^{\circ} \mathrm{C}$ for $18 \mathrm{~h}$. MIC values of the antibiotics and their combination with the tested compounds were determined by naked eyes.

\section{Assay for quorum sensing inhibition}

LB* was used for these experiments. The sensor strain C. violaceum 026 and the AHL producer strains E. cloacae 31298 were inoculated as parallel lines and incubated at room temperature $\left(20^{\circ} \mathrm{C}\right)$ for $24-48 \mathrm{~h}$. QS inhibition was monitored by agar diffusion method. Filter paper discs $(7.0 \mathrm{~mm}$ in diameter) were impregnated with $10 \mu \mathrm{L}$ of stock solutions (10 mM or $10 \mathrm{mg} / \mathrm{mL}$ ) of the CK and PY compounds in DMSO. The discs were 
placed between the parallel lines of the sensor and the AHL producer strains on the surface of the nutrient agar (Figure 9). The plates were incubated at room temperature for another 24-48 $\mathrm{h}$, and the interactions between the strains and compounds were evaluated for the reduction in the size of the zone of pigment production and the zone of growth inhibition of the affected strains, in millimeters ${ }^{153}$. PMZ was applied as a positive control.

C. violaceum

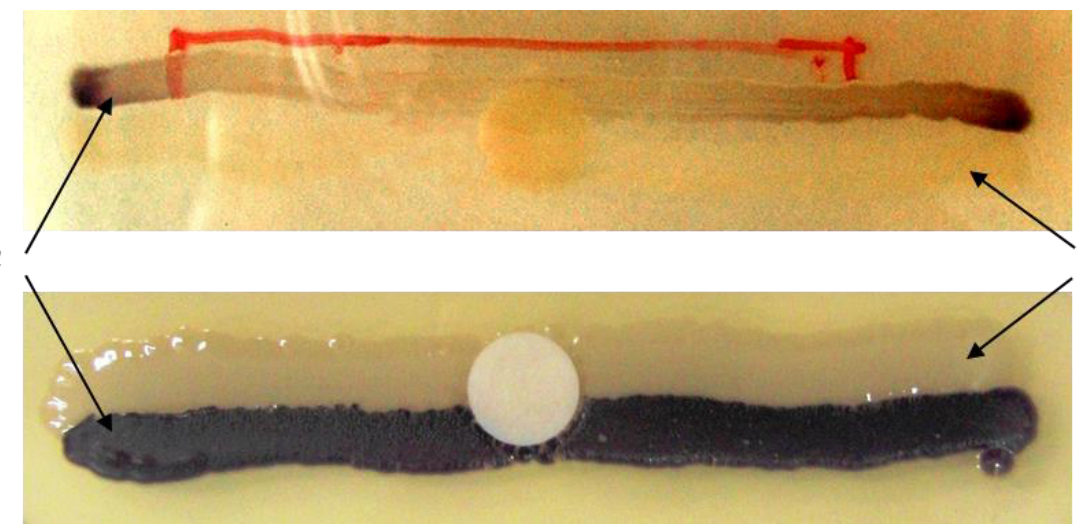

E. cloacae

Figure 9 Positive (promethazine (PMZ; top)) and negative (DMSO; bottom) controls of quorum sensing (QS) on C. violaceum 026 and E. cloacae 31298

\section{Expression analyses of genes by RT-qPCR reaction}

E. coli AG100 strain was cultured in LB broth, S. aureus ATCC 25923 and MRSA 272123 strains were cultured in TSB broth and were incubated overnight at $37^{\circ} \mathrm{C}$ with shaking. On the day of RNA isolation, the bacterial suspensions (OD of 0.6 at $600 \mathrm{~nm}$ ) were transferred to $10 \mathrm{~mL}$ tubes in $3 \mathrm{~mL}$ aliquots, and the compounds $(\mathbf{C K 2}, \mathbf{- 4}$; PY2, -4, $\mathbf{- 5}$ and EDA1, -4, -7) were added to the tubes at $50 \mu \mathrm{M}$ (for EDA1, -4, -7), $50 \mu \mathrm{g} / \mathrm{mL}$ (for PY2, -4, -5), $5 \mu \mathrm{M}$ (for CK2) and $0.5 \mu \mathrm{M}$ (for CK4) concentrations, which were incubated at $37^{\circ} \mathrm{C}$. After 4 hours (for CK2 and -4) or 4 and 18 hours (for PY2, -4, -5 and EDA1, -4, -7) of culturing, the tubes were centrifuged at $12,000 \times g$ for $2 \mathrm{~min}$. Pellets were re-suspended in $100 \mu \mathrm{L}$ Tris-EDTA buffer containing $1 \mathrm{mg} / \mathrm{mL}$ lysozyme by vigorous vortexing, and they were incubated at $37^{\circ} \mathrm{C}$ for $10 \mathrm{~min}$. The total RNA was isolated in an RNase-free environment using NucleoSpin RNA kit (Macherey Nagel, Germany) according to the manufacturer's instructions. Purified RNA was stored in RNase-free water in nuclease-free collection tubes and was maintained at $-20^{\circ} \mathrm{C}$ until quantification was performed. The concentration of the extracted RNA templates was assessed by SmartSpec ${ }^{\mathrm{TM}}$ Plus Spectrophotometer at $260 \mathrm{~nm}$ (Bio-Rad, USA).

Expression of the EP genes norA and mepA in the presence of chamanetin (CK2) and dichamanetin (CK4) was studied by reverse transcription of the total RNA of S. aureus 
ATCC 25923 and MRSA 272123 strains. The data obtained for gene targets were normalized against the $S$. aureus $16 S$ ribosomal RNA gene measured in the same sample. The effect of PY2, -4, -5 and EDA1, -4, -7 on the relative expression of the EP (acrA, acrB), antibiotic resistance (marR) and QS (sdiA) genes were studied in E. coli AG100. The data obtained for gene targets were normalized against the E. coli house-keeping gene glyceraldehide-3-phosphate-dehydrogenase (gapdh) measured in the same sample. The full names of the tested genes are presented in Table 1. The forward and reverse primers used in this assay are shown in Appendix 6.

\begin{tabular}{|c|c|c|}
\hline Gene & Full name & Reference \\
\hline acrA & Acridine resistance protein A & \multirow{3}{*}{158} \\
\hline$a c r B$ & Acridine resistance protein $\mathrm{B}$ & \\
\hline marR & Multiple antibiotic resistance protein $\mathrm{R}$ & \\
\hline$s d i A$ & Quorum-sensing transcriptional activator & This study \\
\hline gapdh & $\begin{array}{c}\text { Glyceraldehyde-3-phosphate } \\
\text { dehydrogenase }\end{array}$ & 158 \\
\hline norA & Quinolone resistance protein NorA & \multirow{3}{*}{159} \\
\hline терA & Multidrug export protein MepA & \\
\hline $16 S r R N A$ & 16S Ribosomal RNA & \\
\hline
\end{tabular}

Table 1 Full name of the tested genes investigated in the RT-qPCR assay

Real-time quantification of the RNA templates by one-step RT-qPCR was performed in a CFX96 Touch real-time PCR detection system (Bio-Rad, USA) strictly adhered to the manufacturer's recommendations of the SensiFAST ${ }^{\mathrm{TM}}$ SYBR No-ROX One-Step Kit (Bioline GmbH, Luckenwalde, Germany). Briefly, each well of the 96-well microtiter plates in a final volume of $20 \mu \mathrm{L}$ contained $10 \mu \mathrm{L}$ of the $2 \mathrm{x}$ SensiFAST ${ }^{\mathrm{TM}}$ SYBR No-ROX OneStep Mix, 0.2 $\mu \mathrm{L}$ reverse transcriptase, $0.4 \mu \mathrm{L}$ ribosafe RNAase inhibitor, $5.4 \mu \mathrm{L}$ diethylpyrocarbonate-treated water, $500 \mathrm{nM}$ of each primer and approximately $20 \mathrm{ng}$ of the 
total RNA in RNAase-free water. Thermal cycling was initiated with a denaturation step of 5 min at $95^{\circ} \mathrm{C}$, followed by 40 cycles, each of $10 \mathrm{~s}$ at $95^{\circ} \mathrm{C}, 30 \mathrm{~s}$ at $57^{\circ} \mathrm{C}$ and $20 \mathrm{~s}$ at $72^{\circ} \mathrm{C}$.

The relative quantities of the mRNA of each gene of interest were determined by the $\Delta \Delta \mathrm{C}_{\mathrm{T}}$ method $^{160}$. Gene transcript levels were normalized against the previously mentioned housekeeping genes. The formula $2^{-\Delta \Delta C}$ T allows the relative quantification of differences of each gene's expression level between two samples, the sample of interest and a calibrator or reference sample. 


\section{RESULTS}

\section{In vitro antibacterial activity of compounds}

\subsection{Bioactive compounds from $C$. kirkii}

Compounds (CK1-CK5) were assessed for their antibacterial activity against methicillin susceptible Staphylococcus aureus ATCC 25923, and the methicillin and ofloxacin resistant S. aureus 272123 clinical isolate. Wild-type Escherichia coli K-12 AG100 and E. coli AG100 A strains, over-expressing and lacking the AcrAB-TolC efflux pump (EP) system, respectively, were used as Gram-negative models. In addition, the antibacterial activity of the compounds was tested on quorum sensing (QS) strains Chromobacterium violaceum 026 and Enterobacter cloacae 31298.

Concerning the antibacterial effect of the compounds, chamanetin (CK2) and dichamanetin (CK4) had a potent antibacterial effect on both S. aureus strains. Minimum inhibitory concentration (MIC) of compound CK2 was $12.5 \mu \mathrm{M}$ on reference $S$. aureus strain; however, the MIC in case of the methicillin and ofloxacin resistant strain was $25 \mu \mathrm{M}$. Compound CK4 was the most effective flavanone because its MIC on $S$. aureus ATCC 25923 strain was $0.8 \mu \mathrm{M}$; furthermore, on the methicillin resistant strain it exhibited the MIC of $1.56 \mu \mathrm{M}$. The compounds had no antibacterial effect on the Gram-negative E. coli AG100, AG100 A, C. violaceum, and E. cloacae strains (MIC: >100 or $100 \mu \mathrm{M}$ ) (Table 2).

\begin{tabular}{|c|c|c|c|c|c|c|}
\hline \multirow[b]{2}{*}{ Compounds } & \multicolumn{6}{|c|}{$M I C(\mu M)$} \\
\hline & $\begin{array}{c}\text { S. aureus } \\
\text { ATCC } \\
25923\end{array}$ & $\begin{array}{c}\text { S. aureus } \\
272123\end{array}$ & $\begin{array}{l}\text { E. coli } \\
\text { AG100 }\end{array}$ & $\begin{array}{c}\text { E. coli } \\
\text { AG100 A }\end{array}$ & $\begin{array}{c}C . \\
\text { violaceum } \\
026\end{array}$ & $\begin{array}{c}E . \\
\text { cloacae } \\
31298\end{array}$ \\
\hline CK1 & $>100$ & $>100$ & $>100$ & $>100$ & $>100$ & $>100$ \\
\hline CK2 & 12.5 & 25 & $>100$ & $>100$ & $>100$ & $>100$ \\
\hline CK3 & 100 & $>100$ & $>100$ & $>100$ & $>100$ & $>100$ \\
\hline CK4 & 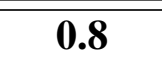 & 1.56 & $>100$ & $>100$ & $>100$ & $>100$ \\
\hline$\overline{\text { CK5 }}$ & $>100$ & $>100$ & $>100$ & $>100$ & $>100$ & $>100$ \\
\hline
\end{tabular}

Table 2 Minimum inhibitory concentrations (MICs) of the $\mathbf{C K}$ compounds isolated from $C$. kirkii on Gram-positive and Gram-negative bacteria 


\subsection{Fluorinated $\beta$-diketo phosphorus ylides}

Compounds (PY1-10) were investigated for their antibacterial activity against wildtype E. coli K-12 AG100 strain, and the AcrAB-TolC pump mutant E. coli AG100 A strain. Furthermore, the antibacterial activity of the compounds was tested on QS strains $C$. violaceum 026 and E. cloacae 31298.

Compounds PY1-10 did not have any antibacterial effect on the AcrAB-TolC expressing $E$. coli AG100, C. violaceum and E. cloacae strain and the AcrAB-TolC deleted E. coli AG100 A strain (MIC: >100 $\mu \mathrm{g} / \mathrm{mL}$ ), except for ethyl-4,4,4-trifluoro-3-oxo-2-(triphenyl phosphoranylidene)butanoate (PY6), which had a mild effect on the EP deleted strain (MIC: $50 \mu \mathrm{g} / \mathrm{mL})($ See Appendix 7).

\subsection{Selenocompounds}

The antibacterial effect of selenocompounds (EDA1-11) were tested on Gramnegative E. coli AG100, E. coli AG100 A, Salmonella enterica serovar Typhimurium SL1344, acrB inactivated S. Typhimurium L644 and S. Typhimurium 14028s strains. Furthermore, the following Gram-positive strains were used: S. aureus ATCC 25923 and Enterococcus faecalis ATCC 29212.

The ketone-containing selenoesters (EDA9-11) showed a potent antibacterial activity against the Gram-positive $S$. aureus ATCC 25923. The methylketone selenoester EDA9 was the most active compound with noteworthy MIC value $(3.12 \mu \mathrm{M})$. The chloro-substituted tert-butylketone selenoester (EDA10) and dimethoxy-substituted tert-butylketone selenoester (EDA11) showed lower antibacterial activity than EDA9 (25 and $50 \mu \mathrm{M}$, respectively). The selenoanhydride EDA1 and the remaining selenoesters EDA2-8 evaluated were inactive as their MIC was equal or above $100 \mu \mathrm{M}$ on S. aureus ATCC 25923. EDA9 showed antibacterial activity towards E. faecalis (MIC: $12.5 \mu \mathrm{M}$ ). The compounds had no antibacterial effect (MIC: $100 \mu \mathrm{M}$ or $>100 \mu \mathrm{M}$ ) on Gram-negative strains (See Appendix 8).

\section{Efflux pump inhibiting activity (accumulation assay)}

\subsection{Bioactive compounds from $C$. kirkii}

The ethidium bromide (EB) accumulation assay provides information about the intracellular accumulation of the general EP substrate EB. A potential efflux pump inhibitor (EPI) increases the fluorescence level of EB because of its accumulation within the bacterial cell. The EP inhibiting activity of the compounds was compared based on the relative fluorescence index (RFI) of the real-time accumulation curves in E. coli AG100, E. coli 
AG100 A, S. aureus ATCC 25923 and S. aureus 272123. In case of real-time EB accumulation by the LightCycler thermocycler, the amount of EB accumulated by cells is higher if the difference between $\mathrm{RF}_{\text {treated }}$ and $\mathrm{RF}_{\text {untreated }}$ is greater; therefore, the degree of inhibition of the EP system by the compound becomes greater.

As shown in Figure 10, CK2 and CK4 had EP inhibiting activity compared to verapamil (RFI: 0.13) on the S. aureus ATCC 25923 strain, and the most active compound was CK2. However, compounds CK1-5 had no EP inhibitory activity on the methicillin resistant $S$. aureus strain at the concentrations applied in the assay (See Appendix 9).

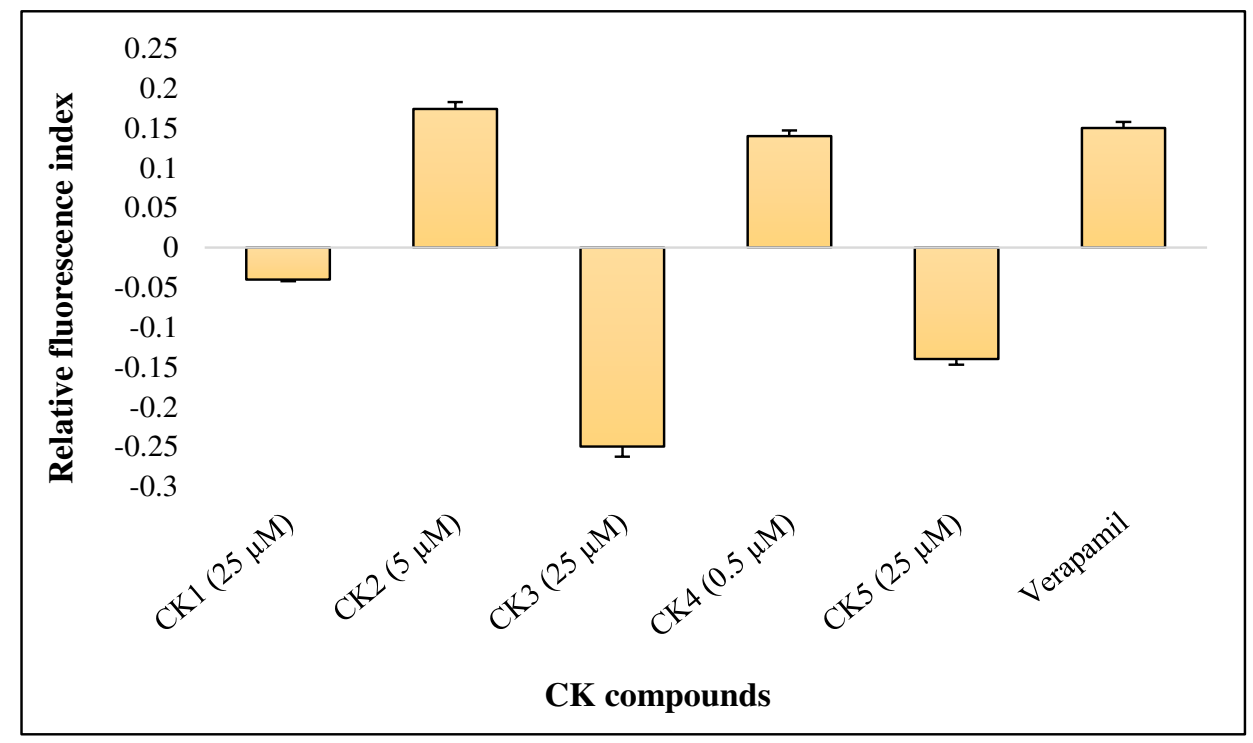

Figure 10 Relative final fluorescence index (RFI) of compounds (CK1-5 isolated from $C$. kirkii) on S. aureus ATCC 25923 at different concentrations

Concerning the inhibitory activity on Gram-negatives, triterpene polycarpol (CK1) and $\mathbf{C K 5}$ could inhibit the AcrAB-TolC system of E. coli AG100 compared to promethazine (PMZ; RFI: 0.15). CK1 proved to be the most effective EPI (Figure 11). Based on the realtime accumulation data, CK1-5 had no effect on the E. coli AG100 A strain lacking the AcrAB-TolC pump (See Appendix 10). 


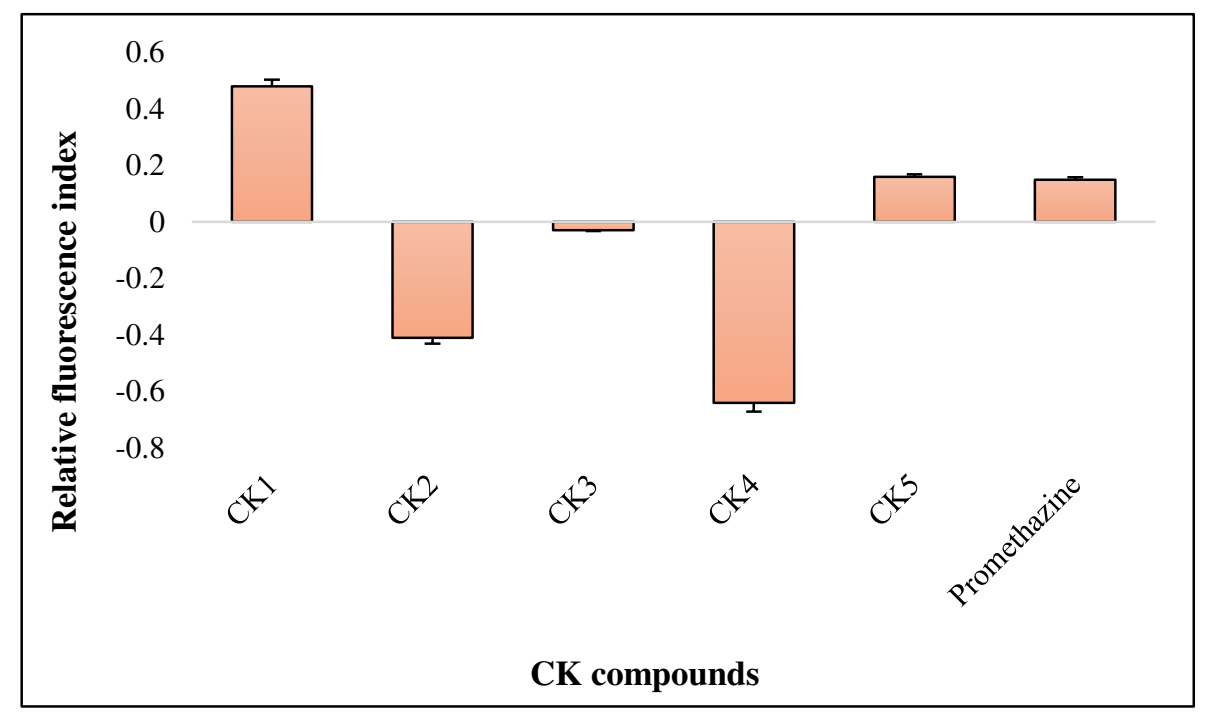

Figure 11 Relative final fluorescence index (RFI) of compounds (CK1-5 isolated from $C$. kirkii) on E. coli AG100 strain at $50 \mu \mathrm{M}$

\subsection{Fluorinated $\beta$-diketo phosphorus ylides}

The EP inhibitory effect was tested on the AcrAB-TolC expressing E. coli AG100 and the mutant AG100 A strains. The majority of the P-ylides were found to inhibit the AcrAB-TolC system of E. coli except trifluoro-1-phenyl-2(triphenylphosphoranylidene)butane-1,3-dione (PY3), 4,4,5,5,5-pentafluoro-1-phenyl-2(triphenylphosphoranylidene)pentane-1,3-dione (PY7) and 4,4,5,5,6,6,6-heptafluoro-1phenyl-2-(triphenylphosphoranylidene)hexane-1,3-dione (PY8), which had little or no effect on the intracellular EB accumulation in both strains. Among the P-ylide series, compounds 1,1,1-trifluoro-3-oxo-1-methoxy-3-(triphenylphosphoranylidene)propane-2-one

(PY2), 4,4,4-trifluoro-3-oxo-2-(triphenylphosphoranylidene)butanal (PY4) and 1,1,1-trifluoro-3(triphenylphosphoranylidene)pentane-2,4-dione (PY5) exhibited strong AcrAB-TolC pumpinhibiting properties compared to the AcrAB-TolC pump-deficient mutant strain. The most potent derivative was PY4 and its effect was more pronounced on the multidrug resistant $E$. coli strain compared to the pump deleted E. coli strain (Figure 12). 


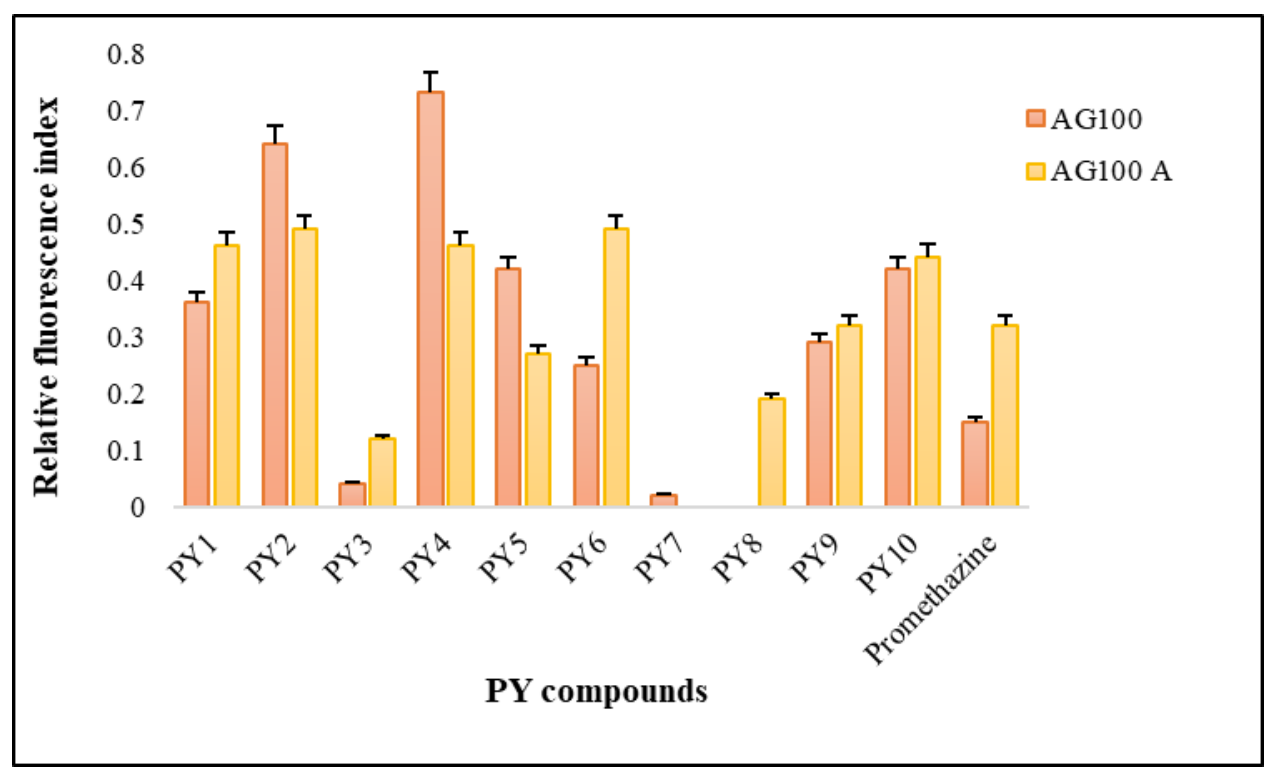

Figure 12 Relative final fluorescence index (RFI) of P-ylides (PY1-10) on the AcrAB-TolC expressing E. coli AG100 and pump deleted E. coli AG100 A strains at $50 \mu \mathrm{g} / \mathrm{mL}$ (except PY6 $(25 \mu \mathrm{g} / \mathrm{mL})$ on AG100 A strain)

\subsection{Selenocompounds}

The ability of the selenocompounds to inhibit the efflux of AcrAB-TolC transporter was determined on E. coli AG100 and AG100 A strains. EDA1 and meta-substituted benzene selenodiester (EDA4), strongly inhibited the efflux mediated by AcrAB-TolC in $E$. coli AG100 compared to the positive control PMZ (RFI: 0.15). Methoxycarbonylmethyl selenoester (EDA7) and EDA9-11 caused moderate inhibitory action, whereas thiophene selenodiester (EDA2), pyridine selenodiester (EDA3), para-substituted benzene selenodiester (EDA5), carbamoylmethyl selenoester (EDA6) and phenoxycarbonyl selenoester (EDA8) showed weak or no activity on the intracellular EB accumulation in $E$. coli AG100. Nevertheless, no EP inhibitory action was found in the E. coli AG100 A strain in case of selenocompounds (EDA1-11) (Figure 13). 


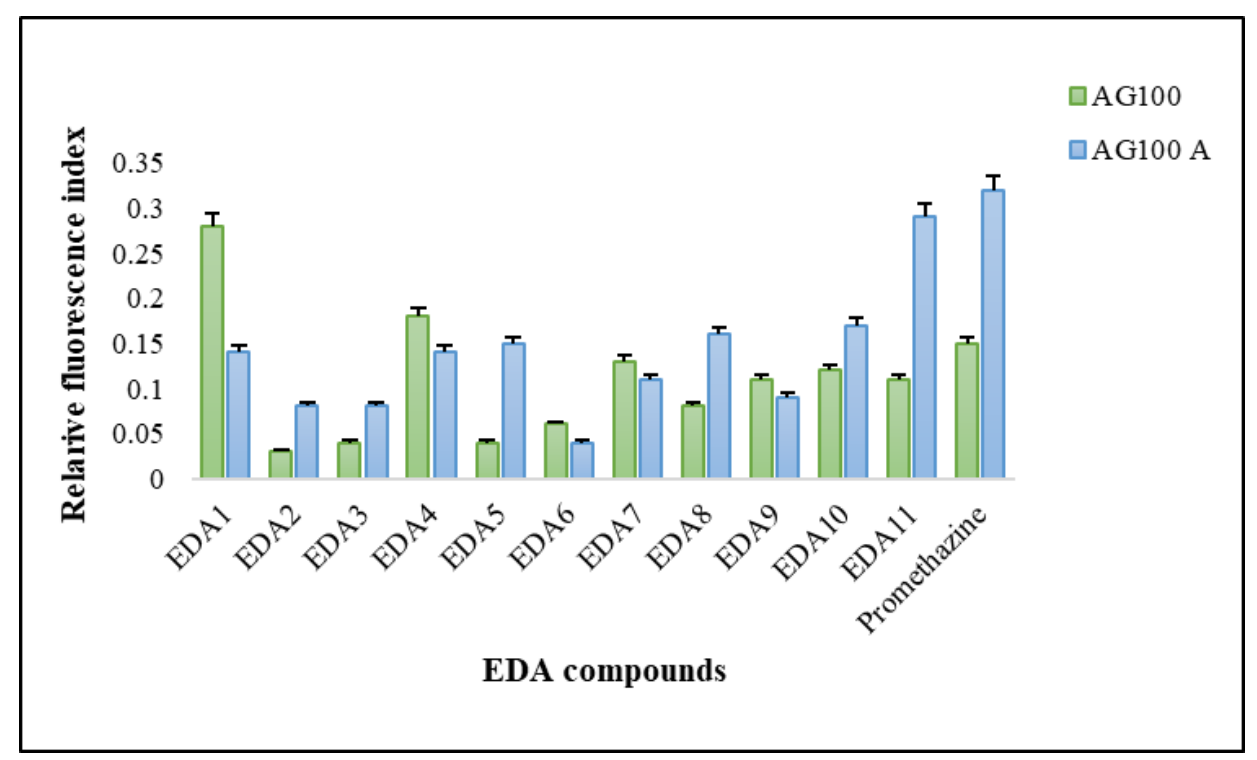

Figure 13 Relative final fluorescence index (RFI) of selenocompounds (EDA1-11) on the AcrAB-TolC expressing E. coli AG100 and pump deleted E. coli AG100 A strains at $50 \mu \mathrm{M}$

\section{Efflux pump inhibiting activity (efflux assay)}

In the EB efflux assay, after loading the wild-type $S$. Typhimurium SL1344 and acrB mutant L644 strains with EB the active efflux of the dye was measured as the time taken for fluorescence drops by $25 \%$ and $50 \%$ compared to the starting fluorescence level. Each selenocompound showed a $25 \%$ and $50 \%$ decrease in fluorescence at an earlier time point (25\%: between $4.5^{\text {th }}$ and $17.8^{\text {th }}$ min; 50\%: between $7.9^{\text {th }}$ and $79.2^{\text {nd }} \min$ ), compared with positive control CCCP (25\%: in 52.1 $1^{\text {st }} \mathrm{min}$; 50\%: in $122.6^{\text {th }} \mathrm{min}$ ) in S. Typhimurium SL1344 (Table 3). The EB efflux was most effectively inhibited in the presence of EDA9 as fluorescence intensity of EB was reduced by half in the $79.2^{\text {nd }}$ minutes. For the L644 strain only EDA7 was able to prevent the efflux of EB more effectively than carbonyl cyanide $m$ chlorophenyl hydrazone (CCCP) (Table 3). 


\begin{tabular}{|c|c|c|c|c|}
\hline \multirow{3}{*}{ Samples } & \multicolumn{4}{|c|}{ Time taken (min) for percentage } \\
\hline & \multicolumn{2}{|c|}{$\begin{array}{l}\text { S. Typhimurium } \\
\text { SL1344 }\end{array}$} & \multicolumn{2}{|c|}{$\begin{array}{c}\text { S. Typhimurium } \\
\text { L644 }\end{array}$} \\
\hline & $-25 \%$ & $-50 \%$ & $-25 \%$ & $-50 \%$ \\
\hline $\begin{array}{l}\text { Untreated control }= \\
\text { Bacterial control }\end{array}$ & 5.4 & 9.6 & 8 & 14.1 \\
\hline CCCP & 52.1 & 122.6 & 42.1 & 117.6 \\
\hline EDA1 & 9.7 & 55.3 & 28 & 78.4 \\
\hline EDA2 & 17.8 & 56.8 & 31.5 & 88.6 \\
\hline EDA3 & 4.5 & 7.9 & 9.9 & 21 \\
\hline EDA4 & 17.2 & 56.1 & 21.6 & 83.2 \\
\hline EDA5 & 5.3 & 11.0 & 10.1 & 26.3 \\
\hline EDA6 & 5.4 & 11.0 & 111.8 & 30.5 \\
\hline EDA7 & 12.2 & 58.9 & 55.2 & 119.5 \\
\hline EDA8 & 5.5 & 9.5 & 9 & 16.8 \\
\hline EDA9 & 15.6 & 79.2 & 37.8 & 86.1 \\
\hline EDA10 & 17.1 & 65.6 & 18.8 & 80.8 \\
\hline EDA11 & 19.8 & 30.7 & 15 & 32 \\
\hline
\end{tabular}

Table 3 Time taken for fluorescence to drop by $25 \%$ and $50 \%$ of starting value in wild-type

S. Typhimurium SL1344 and its $a c r B$ mutant L644 strains in the presence of selenocompounds at $50 \mu \mathrm{M}$

\section{Anti-biofilm activity of selenocompounds}

The anti-biofilm effect of selenocompounds (EDA1-11) was evaluated by microdilution method using crystal violet $(\mathrm{CV})$ on $S$. Typhimurium 14028 s strain. Except compounds EDA6 and dimethoxy-substituted tert-butylketone selenoester (EDA11) all derivatives showed significant $(>45 \%$; $p<0.05)$ or higher biofilm inhibition at $50 \mu \mathrm{M}$ on $S$. Typhimurium. The most potent selenocompounds with anti-biofilm effect were EDA4 and 5 at $50 \mu \mathrm{M}$ showing $75 \%$ and $73 \%$ of inhibition, respectively (Figure 14). 


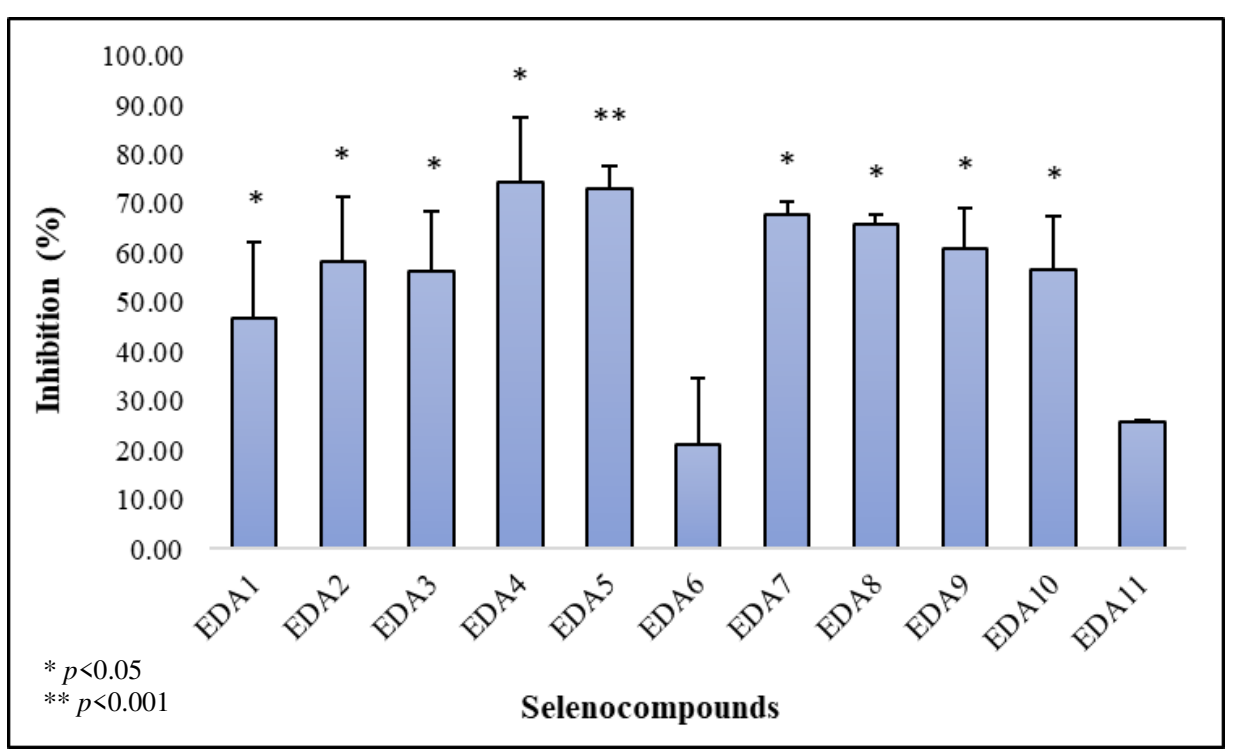

Figure 14 Anti-biofilm effect of selenocompounds on $S$. Typhimurium 14028s at $50 \mu \mathrm{M}$

\section{Combined effects of chamanetin (CK2) and dichamanetin (CK4) with antibiotics}

The type of interaction between the antibacterial compounds CK2, CK4 and tetracycline (TET) and the fluoroquinolone antibiotic ciprofloxacin (CIP) was evaluated on reference (ATCC 25923) and methicillin resistant (MRSA 272123) S. aureus strains by checkerboard assay. The results are presented in Tables 5 and 6 as combination index values $^{157}$. As it can be observed the combined effect of TET and compounds CK2 or CK4 on $S$. aureus ATCC 25923 resulted in synergism. The most effective ratio of antibiotic and compound was 1:20 and 1:1, respectively. Similarly, CIP also acted synergistically with compounds CK2 and CK4 and the most active ratio of antibiotic and compound was 1.3:12.5 and 1.3:1, respectively (Table 4).

\begin{tabular}{|l|c|c|c|c|}
\hline \multicolumn{5}{|c|}{ Staphylococcus aureus ATCC 25923 } \\
\hline Combination & Best Ratio & CI at ED90 & SD (+/-) & Interaction \\
\hline \hline TET + CK2 & $1: 20$ & 0.64 & 0.13 & Synergism \\
\hline \hline TET + CK4 & $1: 1$ & 0.42 & 0.1 & Synergism \\
\hline \hline CIP + CK2 & $1.3: 12.5$ & 0.82 & 0.24 & Slight synergism \\
\hline \hline CIP + CK4 & $1.3: 1$ & 0.69 & 0.28 & Synergism \\
\hline
\end{tabular}

Ratio: antibiotic and tested compound $(\mu \mathrm{M})$. CI: combination index. $\mathrm{CI}<1, \mathrm{CI}=1$ and $\mathrm{CI}>1$ represent synergism, additive effect (or no interaction), and antagonism, respectively.

Table 4 Combined effect of CK2 and CK4 with antibiotics on S. aureus ATCC 25923 strain 
On the methicillin resistant $S$. aureus strain CK2 showed antagonistic effect with TET and slight synergism with CIP. The interactions of CK4 with TET and CIP on the resistant $S$. aureus strain were synergism and moderate antagonism respectively (Table 5).

\begin{tabular}{|l|c|c|c|c|}
\hline \multicolumn{5}{|c|}{ Staphylococcus aureus 272123 } \\
\hline Combination & Best Ratio & CI at ED90 & SD (+/-) & Interaction \\
\hline \hline TET + CK2 & $6: 25$ & 1.5 & 0.29 & Antagonism \\
\hline \hline TET + CK4 & $100: 1$ & 0.59 & 0.35 & Synergism \\
\hline \hline CIP + CK2 & $13: 8$ & 0.85 & 0.22 & Slight synergism \\
\hline \hline CIP + CK4 & $32: 1$ & 1.35 & 0.25 & Moderate antagonism \\
\hline
\end{tabular}

Ratio: antibiotic and tested compound $(\mu \mathrm{M})$. CI: combination index. $\mathrm{CI}<1, \mathrm{CI}=1$ and $\mathrm{CI}>1$ represent synergism, additive effect (or no interaction), and antagonism, respectively.

Table 5 Combined effect of CK2 and CK4 with antibiotics on S. aureus 272123 strain

\section{Enhancement of the activity of antibiotics in the presence of selenocompounds}

The combination effect of selenocompounds with TET and CIP was defined by MIC reduction assay on AcrAB-TolC expressing E. coli AG100 strain. In the absence of selenocompounds, TET showed MIC value of $4.2 \mu \mathrm{M}$ and CIP exhibited MIC of $0.02 \mu \mathrm{M}$. EDA9 potentiated the effect of TET and CIP, furthermore EDA10 reduced the MIC value of CIP by two-fold in E. coli strain (Table 6).

\begin{tabular}{|c|c|c|}
\hline \multirow{2}{*}{ Compounds } & \multicolumn{2}{|c|}{ Escherichia coli AG100 } \\
\cline { 2 - 3 } & Reduction of TET MIC & Reduction of CIP MIC \\
\hline \hline EDA1-8; EDA11 & no effect & no effect \\
\hline \hline EDA9 & 2-fold & 2-fold \\
\hline \hline EDA10 & no effect & 2-fold \\
\hline
\end{tabular}

MIC values of TET and CIP alone: $4.2 \mu \mathrm{M}$ and $0.02 \mu \mathrm{M}$, respectively.

Table 6 Fold change in reduction of the MICs of selected antibiotics on E. coli AG100 in the presence of selenocompounds

\section{Anti-quorum sensing activity}

\subsection{Bioactive compounds from $C$. kirkii}

The QS inhibiting activity of compounds was defined as measuring the colorless zone around the disc on $C$. violaceum as described previously ${ }^{153}$. Compounds CK1, -2, -4, and -5 
were able to inhibit effectively the QS between $C$. violaceum and E. cloacae compared to the positive control PMZ (Table 7).

\begin{tabular}{|l|c|}
\hline \multicolumn{1}{|c|}{ Compounds } & QS inhibition zone in $\mathbf{m m}$ \\
\hline CK1 & $\mathbf{5 1}$ \\
\hline \hline CK2 & $\mathbf{5 0}$ \\
\hline \hline CK3 & - \\
\hline CK4 & $\mathbf{5 3}$ \\
\hline \hline CK5 & $\mathbf{5 2}$ \\
\hline \hline Promethazine (PMZ) & 46 \\
\hline
\end{tabular}

$10 \mu \mathrm{L}$ of $10 \mathrm{mM}$ stock solution was added onto the filter paper discs $(10 \mu \mathrm{M} / \mathrm{disc})$ and the colorless zone around the disc was determined on $C$. violaceum. The inhibition was measured after incubation for 24-48 h at room temperature

Table 7 Inhibitory effects of compounds CK1-5 on quorum sensing (QS) signal transmission.

\subsection{Fluorinated $\beta$-diketo phosphorus ylides}

P-ylides were not able to inhibit the QS (inhibition zone: $0 \mathrm{~mm}$ ) in the applied systems compared to the positive control PMZ.

\section{Relative expressions of genes related to antibiotic resistance, quorum sensing and efflux pumps}

\subsection{Bioactive compounds from $C$. kirkii}

In order to evaluate the effect of compounds on the relative expression of EP genes in both $S$. aureus strains, the most effective compounds CK2 and CK4 were selected for gene expression studies. In the reverse transcriptase quantitative polymerase chain reaction (RTqPCR) assay the genes of NorA and MepA transporters were investigated. As shown in Figure 15/A CK2 at $5 \mu \mathrm{M}$ significantly up-regulated the expression of norA and mepA genes after $4 \mathrm{~h}$ of exposure in methicillin resistant $S$. aureus strain. Compound $\mathbf{C K} 4$ at $0.5 \mu \mathrm{M}$ also significantly up-regulated both EP genes after $4 \mathrm{~h}$ of exposure in S. aureus 272123 as presented in Figure 15/B. In S. aureus ATCC 25923 strain, the expression level of the mepA gene was not influenced. Nevertheless, the norA gene was significantly up-regulated by compounds CK2 (19.84-fold increase) at $5 \mu \mathrm{M}$ and CK4 (2.39-fold increase) at $0.5 \mu \mathrm{M}$ (data not shown). 

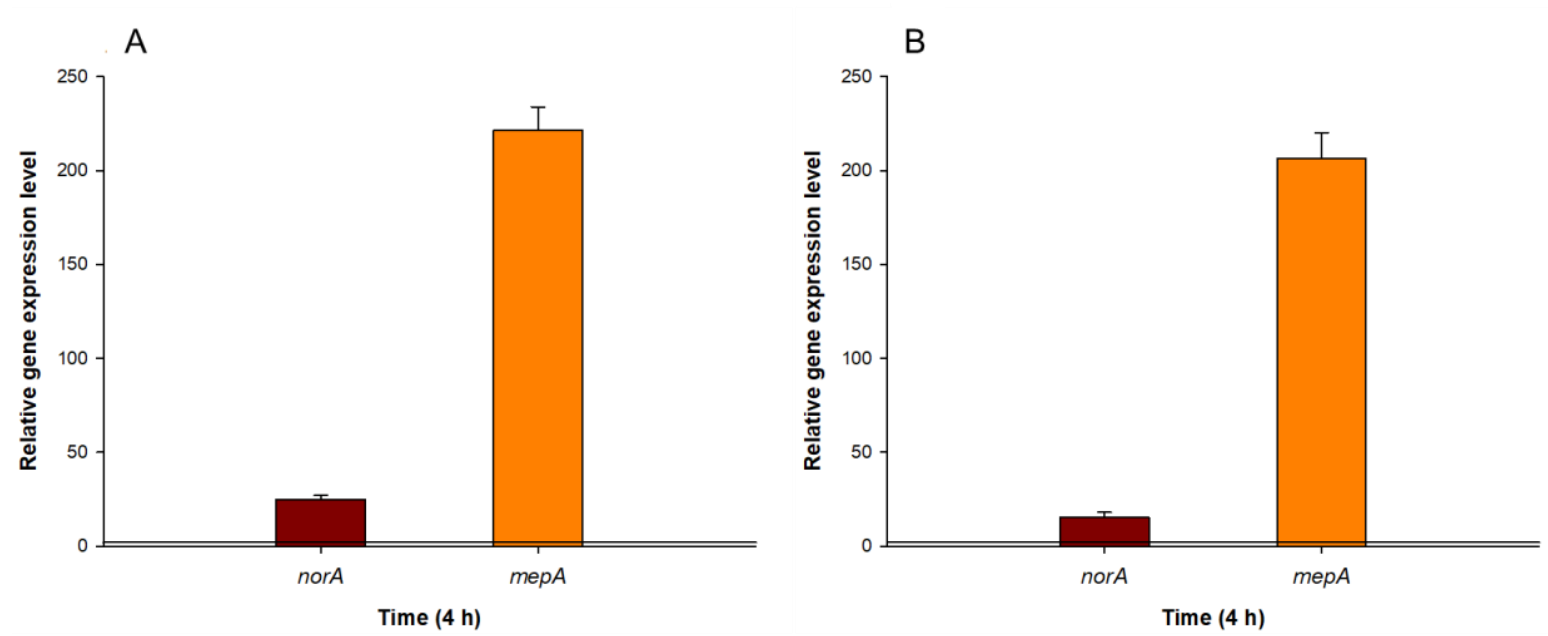

Figure 15 Relative gene expression levels of norA and mepA genes in the presence of CK2 (A) and CK4 (B) at the concentration of $5 \mu \mathrm{M}$ (CK2) and $0.5 \mu \mathrm{M}$ (CK4), respectively in $S$. aureus 272123 , after $4 \mathrm{~h}$ exposure. The line denotes the threshold value, which was set at a two-fold increase in transcripts

\subsection{Fluorinated $\beta$-diketo phosphorus ylides}

Regarding the effect of P-ylides on the relative expression of EP and QS genes in $E$. coli AG100 the most effective PY2, -4, and -5 compounds were selected for gene expression studies. In the assay the gene of the multidrug EP subunit AcrB, the periplasmic AcrA subunit, the component of the E. coli mar locus and the gene of the LuxR homologue SdiA were investigated. As shown in Figure 16/A PY2 at $50 \mu \mathrm{g} / \mathrm{mL}$ up-regulated all the genes studied after $4 \mathrm{~h}$ of exposure, however, after $18 \mathrm{~h}$ the gene expression returned to basal levels. PY4 also significantly up-regulated the secondary resistance-nodulation-division family (RND) transporter gene $a c r B$ (approximately 2 -fold increase) after $4 \mathrm{~h}$ and $18 \mathrm{~h}$ exposures as well. Surprisingly, there was an up-regulation in the expression of sdiA after $18 \mathrm{~h}$ compared to the expression level after $4 \mathrm{~h}$ implicating the ability of PY2 to influence $s d i A$, however, this increase was not significant (Figure 16/B). PY5 up-regulated the expression levels of acrA and $a c r B$ after $4 \mathrm{~h}$, although after $18 \mathrm{~h}$ the up-regulation of these genes was not significant (less than 2-fold increase) as presented by Figure 16/C. 

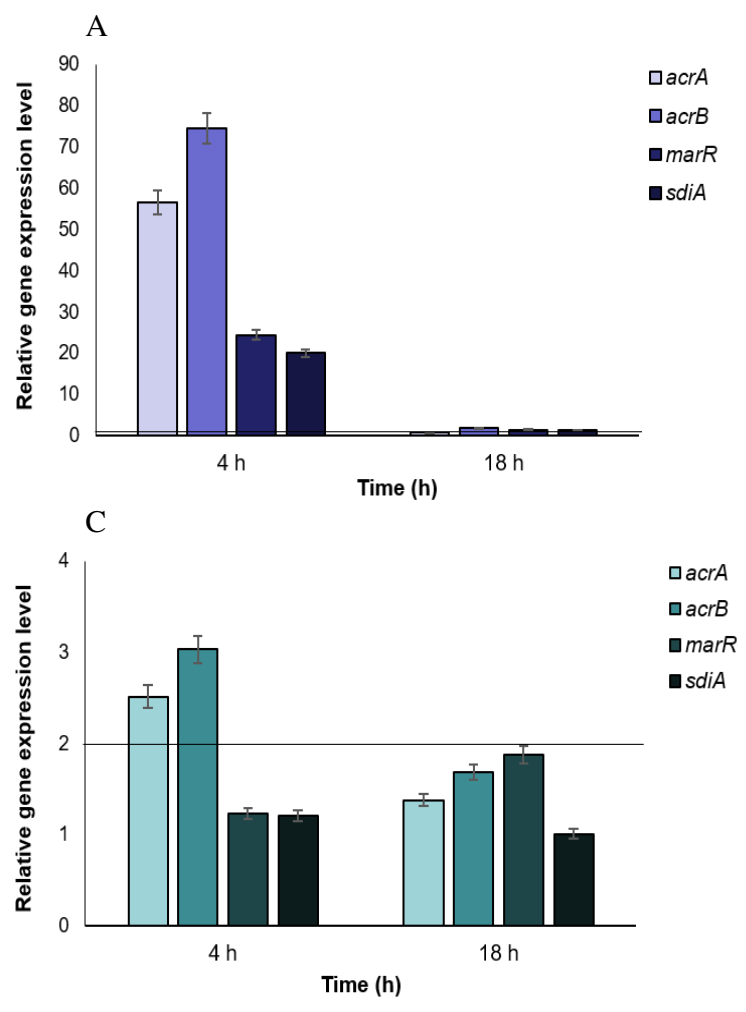

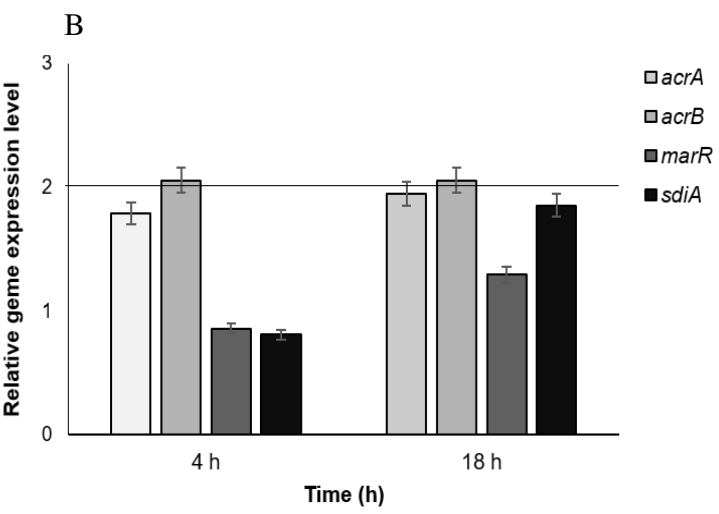

Figure 16 Relative gene expression levels of acrA, acrB, marR and sdiA in the presence of PY2 (A), PY4 (B), and PY5 (C) at the concentration of $50 \mu \mathrm{g} / \mathrm{mL}$ in $E$. coli AG100 after 4 and $18 \mathrm{~h}$. The line denotes a threshold value, which was set at a two-fold increase in transcripts

\subsection{Selenocompounds}

Regarding the effect of selenocompounds on the relative expression of EP, antibiotic resistance and QS genes in E. coli AG100, the most effective EDA compounds -1, $\mathbf{- 4}$ and -7 were examined by gene expression analysis. In the assay, the gene of AcrB, AcrA, SdiA and the component of the E. coli mar locus were investigated. As shown in Figure 17/A, EDA1 at $50 \mu \mathrm{M}$ significantly up-regulated $\operatorname{acr} B, \operatorname{mar} R$ and $s d i A$ genes studied after $4 \mathrm{~h}$ of exposure, however, after $18 \mathrm{~h}$, the expression of $a c r B$ gene returned to basal level and the marR and $s d i A$ genes increased significantly. EDA4 up-regulated the expression of $\operatorname{acr} B, \operatorname{mar} R$ and $s d i A$ after $4 \mathrm{~h}$ although after $18 \mathrm{~h}$ the expression levels of $a c r B$ and $m a r R$ genes decreased. The QS gene $s d i A$ was significantly up-regulated after 18 h (Figure 17/B). EDA7 also significantly up-regulated marR after $4 \mathrm{~h}$ and $18 \mathrm{~h}$ exposures. After $18 \mathrm{~h}$ the RND transporter subunit genes $(a c r A, a c r B)$ were significantly up-regulated in the presence of EDA7 (Figure 17/B). 

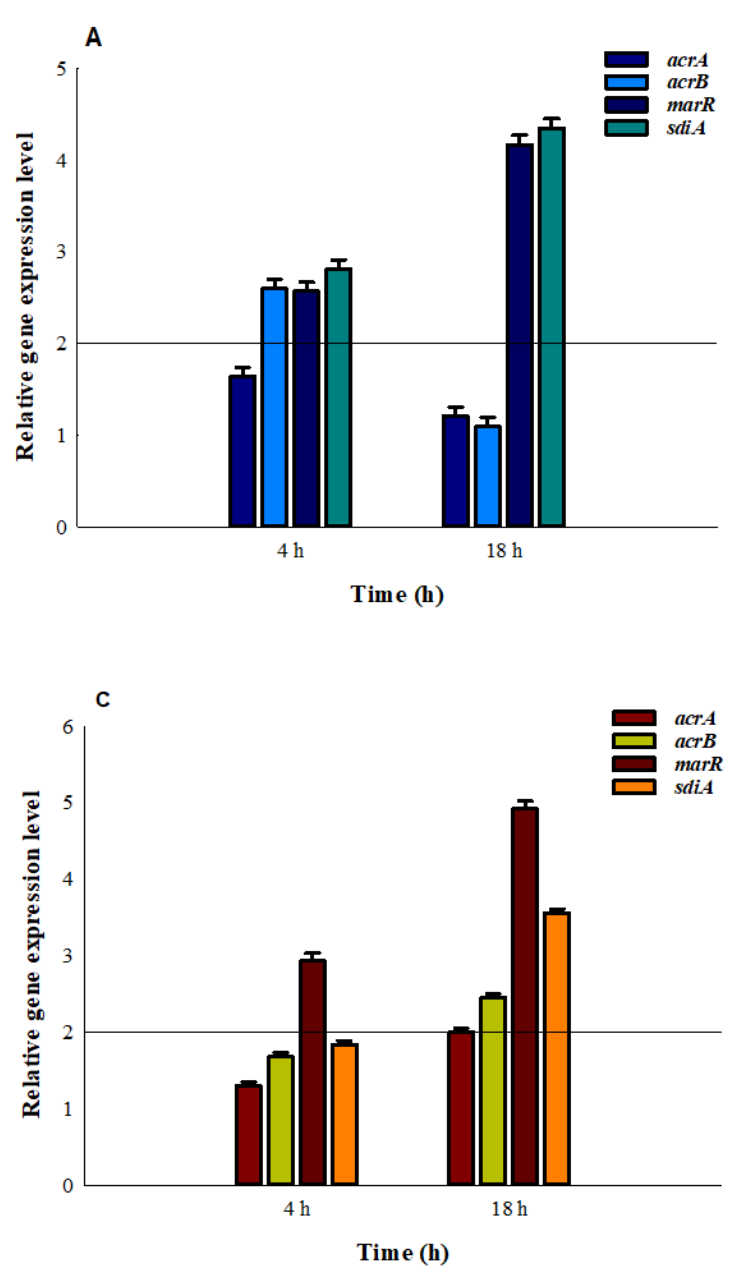

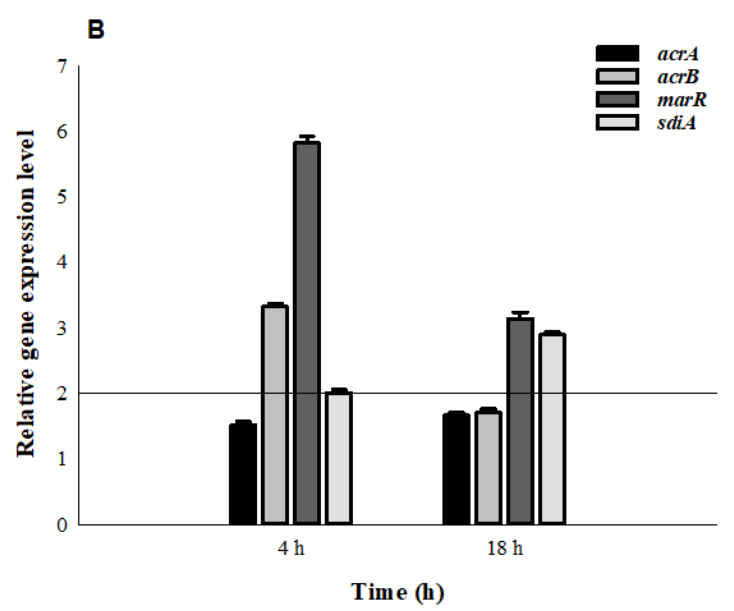

Figure 17 Relative gene expression levels of acrA, acrB, marR and sdiA genes in the presence of EDA1 (A), EDA4 (B), and EDA7 (C) at the concentration of $50 \mu \mathrm{M}$ in E. coli AG100 after 4 and $18 \mathrm{~h}$. The line denotes a threshold value, which was set at a two-fold increase in transcripts. 


\section{DISCUSSION}

Multidrug resistance to antibiotics has become a serious problem in the treatment of infectious diseases. One of the most important mechanisms causing multidrug resistance is the over-expression of efflux pumps (EPs), whereby cells pump out toxic substances to the exterior of the cells. Infections caused by multidrug resistant bacteria lead to increased treatment costs and may result in fatal outcomes; consequently, it is a major challenge for drug development in order to discover new efflux pump inhibitors (EPIs).

The natural, plant-derived or synthetic compounds may represent a valuable source of new antibacterial agents because they can inhibit the growth of bacteria and the activity of bacterial efflux systems which indirectly prevent the formation of biofilm and the bacterial cell-to-cell communication system, furthermore, they can potentiate the efficacy of antibiotics as well.

The main goal of our study was to evaluate the antibacterial and multidrug resistance reversing effects of bioactive compounds from Chleistochlamys kirkii (CK1-5), fluorinated $\beta$ diketo phosphorus ylides (PY1-10) and selenocompounds (EDA1-11) in different bacterial models. The following methods were used in the studies: minimum inhibitory concentration (MIC) determination, ethidium bromide (EB) accumulation and efflux assay, checkerboard combination method, MIC reduction assay, biofilm, quorum sensing (QS) inhibitory test and reverse transcriptase quantitative polymerase chain reaction (RT-qPCR).

\section{Bioactive compounds from C. kirkii (CK1-5)}

According to this study chamanetin (CK2) and dichamanetin (CK4) had the most pronounced antibacterial activity in case of methicillin sensitive and resistant Staphylococcus aureus strains. These results are supported by previous studies ${ }^{139}$. Dichamanetin showed stronger effect than chamanetin, due to its higher lipophilic character resulting from the extra benzyl group at C-6. In contrast to chamanetin, isochamanetin (CK3), differing only in the position of benzyl substituents, was inactive at the concentration tested. Thus, besides the importance of lipophilicity, the presence of a benzyl moiety at C-8 appears to play a decisive role in the antibacterial activity of this type of compounds. In the combination assays, chamanetin and dichamanetin showed synergism with tetracycline (TET) and ciprofloxacin (CIP) on the $S$. aureus reference strain. Furthermore, on the methicillin resistant S. aureus (MRSA) strain, chamanetin and dichamanetin, combined with TET and CIP, respectively, also showed synergism, which indicates that these compounds could be potential adjuvants in 
the therapy. Besides having an antibacterial effect, both chamanetin and dichamanetin could inhibit the activity of EPs compared to the positive control. Furthermore, these compounds inhibited the QS between Chromobacterium violaceum 026 and Enterobacter cloacae 31298, and they caused over-expression of EP genes (norA and mepA) after $4 \mathrm{~h}$ of exposure in the MRSA strain. The change in gene expression could be due to the stress response against chamanetin and dichamanetin because these compounds as potential noxious agents for $S$. aureus had to be extruded from the cytoplasm of the bacterium as soon as possible. This stress response can be the explanation for the up-regulation of the EP genes after $4 \mathrm{~h}$. Chamanetin and dichamanetin influenced the expression of mepA gene in the MRSA strain, however, these compounds did not have any effect on the expression level of mepA in the reference $S$. aureus strain. The difference between methicillin resistant $S$. aureus and methicillin susceptible reference $S$. aureus strains is due to the over-expression of the mepA gene in the resistant strain and it has low expression level in the reference strain. It has been demonstrated by other studies that the over-expression of EPs confers a fitness cost for the organism, for example, a resistant isolate over-expressing EPs shows reduced production of virulence determinants. Usually the over-expression of pump genes is often related to global effects on bacterial physiology influencing virulence ${ }^{161}$. In Gram-negatives, compounds CK1-5 did not show antibacterial activity. The highly lipophilic polycarpol (CK1) inhibited the resistance-nodulation-division (RND) transporter AcrAB-TolC transport system in Escherichia coli AG100 strain because it could increase the membrane permeability of bacteria $^{139}$. In contrast polycarpol had no EPI effect on the pump mutant E. coli AG100 A strain confirming that it may have a direct EPI effect on the AcrAB-TolC EP. In addition, apart from chamanetin and dichamanetin, polycarpol and acetylmelodorinol (CK5) were also able to inhibit effectively the bacterial communication, suggesting that they could be applied as anti-QS agents.

\section{Fluorinated $\beta$-diketo phosphorus ylides (PY1-10)}

In our previous study trifluoro-1-phenyl-2-(triphenylphosphoranylidene)butane-1,3dione (PY3), 4,4,5,5,5-pentafluoro-1-phenyl-2-(triphenylphosphoranylidene)pentane-1,3dione (PY7) and 4,4,5,5,6,6,6-heptafluoro-1-phenyl-2-(triphenylphosphoranylidene)hexane1,3-dione (PY8) have been shown to have activity against the EPs of cancer cells ${ }^{141}$, but did not show any activity against the EPs of E. coli strains. The aim of the previous work was to examine the primary ATP-binding cassette subfamily B member (ABCB1) EP inhibitory effect of PY compounds in cancer cells, in the present study the compounds have been tested 
against the secondary AcrAB-TolC system in bacteria. It is important to note that ATPbinding cassette $(\mathrm{ABC})$ transporters derive their energy from the hydrolysis of ATP, however, the AcrAB-TolC system is a proton motive force (PMF)-dependent multidrug efflux system. The most effective compounds in E. coli AG100 were 1,1,1-trifluoro-3-oxo-1-methoxy-3-(triphenylphosphoranylidene)propane-2-one (PY2), 4,4,4trifluoro-3-oxo-2-(triphenylphosphoranylidene)butanal (PY4), and 1,1,1-trifluoro-3(triphenylphosphoranylidene)pentane-2,4-dione (PY5), which inhibited the AcrAB-TolC system and influenced the expression of the transporter genes acrA and $\operatorname{acr} B$. In addition, although the compounds are not QS inhibitors, PY4 increased the expression of sdiA after 18 $\mathrm{h}$ exposure. The compounds in the $\mathrm{R}^{1}$ chain contain a trifluoromethyl ketone $\left(\mathrm{COCF}_{3}\right)$ and the $\mathrm{R}^{2}$ chain is a methoxy (OMe; PY2), formyl (CHO; PY4), and acetyl (COMe; PY5) substituent. Thus, some structurally related fluorinated $\beta$-diketo phosphorus ylides differ in their multidrug resistance reversal activities between cancer cells and bacterial strains, indicating that the compounds act differently as inhibitors of $\mathrm{ABCB} 1$ and AcrB EPs because these pumps differ in their structure and energy source driving the pump (ATP and PMF, respectively $)^{74}$.

\section{Selenocompounds (EDA1-11)}

These novel selenocompounds were studied previously for anticancer and ABCB1 EP inhibitory activity in different cancer cells ${ }^{149-151,162}$. According to the results on bacteria it was found that the ketone-containing selenoesters EDA9-11 showed antibacterial activity against S. aureus reference strain, furthermore the methylketone selenoester (EDA9) was effective on Enterococcus faecalis ATCC 29212. In the EB accumulation assay the cyclic selenoanhydride (EDA1) and the meta-substituted benzene selenodiester (EDA4) could inhibit the activity of the AcrAB-TolC EP system and they were more potent than the positive control promethazine (PMZ) in E. coli AG100. Methylketone selenoester significantly inhibited the efflux mechanism of wild-type Salmonella enterica serovar Typhimurium SL1344 strain. EP inhibiting activity has been found for methoxycarbonylmethyl selenoester (EDA7) in the $a c r B$ mutant $S$. Typhimurium strain. From the results obtained in the EB efflux assay, it can be concluded that the same compounds had EP inhibitory activity in the wild-type and mutant $S$. Typhimurium strains as well. The similarities observed in the efflux assay of compounds mean that the derivatives do not directly inhibit the AcrAB-TolC system of $S$. Typhimurium.

Results showed that the meta-substituted benzene selenodiester (EDA4) and para-substituted benzene selenodiester (EDA5), which contain a phenyl ring, were the strongest inhibitors of 
biofilm formation in $S$. Typhimurium 14028s, indicating the promising potential of these two difunctionalized derivatives against this Gram-negative strain assayed. EDA7-10 and the thiophene selenodiester (EDA2) and pyridine selenodiester (EDA3) also exerted a biofilm inhibiting activity higher than $50 \%$ and the inclusion of an amide group (carbamoylmethyl selenoester; EDA6) or of a 3,5-dimethoxyphenyl moiety (dimethoxy-substituted tertbutylketone selenoester; EDA11) significantly reduced the biofilm formation in $S$. Typhimurium 14028s. Methylketone selenoester reduced the MIC value of TET by 2-fold, furthermore this compound and chloro-substituted tert-butylketone selenoester potentiated the activity of TET and CIP on E. coli AG100. In the gene expression analysis, we observed that cyclic selenoanhydride, meta-substituted benzene selenodiester, and methoxycarbonylmethyl selenoester influenced the gene expression of resistance (and transporter) genes because these derivatives significantly up-regulated the marR gene after 4 and $18 \mathrm{~h}$ exposure, respectively. Furthermore, the QS gene sdiA was significantly up-regulated in the presence of cyclic selenoanhydride, after exposures of $4 \mathrm{~h}$ and $18 \mathrm{~h}$.

According to the results these studies indicated that natural and synthetic compounds could be used as potential antibacterial agents alone or combination with antibiotics for the treatment of infectious diseases. In addition, our studies are suggesting the importance of the substituent's topology and moiety for the biological potency. In future studies, it will be necessary to design and analyze systematically more compounds and understand the structure-activity relationships in order to develop potent resistance modifiers. 


\section{NEW FINDINGS}

\section{Bioactive compounds from Cleistochlamys kirkii}

- Chamanetin (CK2) and dichamanetin (CK4) with a benzyl moiety at C-8 showed potent antibacterial effect against methicillin susceptible Staphylococcus aureus ATCC 25923 and methicillin and ofloxacin resistant S. aureus 272123 strains. Moreover, dichamanetin proved to be the most active compound isolated from $C$. kirkii on these strains and has higher lipophilic character compared to chamanetin due to its extra benzyl group at C-6.

- Dichamanetin had synergistic activity with tetracycline and ciprofloxacin on S. aureus reference strain. Furthermore, dichamanetin showed synergism in combination with tetracycline on the methicillin and ofloxacin resistant $S$. aureus strain.

- Chamanetin and acetylmelodorinol (CK5) had potent efflux pump modulatory effects in S. aureus reference strain. Polycarpol (CK1) was the most effective efflux pump inhibitor on Escherichia coli AG100 inhibiting the AcrAB-TolC transporter system.

- All bioactive compounds of $C$. kirkii except isochamanetin (CK3) were able to inhibit effectively the bacterial quorum sensing system.

\section{Fluorinated $\beta$-diketo phosphorus ylides}

- 1,1,1-trifluoro-3-oxo-1-methoxy-3-(triphenylphosphoranylidene)propane-2-one (PY2), 4,4,4-trifluoro-3-oxo-2-(triphenylphosphoranylidene)butanal (PY4), and 1,1,1trifluoro-3-(triphenylphosphoranylidene)pentane-2,4-dione (PY5) inhibited directly the AcrAB-TolC efflux transporter in E. coli AG100 strain compared to the AcrABTolC pump mutant AG100 A strain.

\section{Selenocompounds}

- Methylketone selenoester (EDA9) had antibacterial activity against the reference $S$. aureus ATCC 25923 and Enterococcus faecalis ATCC 29212 strains.

- Methylketone selenoester potentiated the effect of tetracycline and ciprofloxacin on the AcrAB-TolC expressing E. coli AG100 strain.

- Almost all selenocompounds showed potent anti-biofilm activity against Salmonella enterica serovar Typhimurium 14028s strain.

- Cyclic selenoanhydride (EDA1), meta-substituted benzene selenodiester (EDA4) and methoxycarbonylmethyl selenoester (EDA7) were the most active inhibitors of the AcrAB-TolC system in E. coli AG100 strain. 


\section{SUMMARY}

Multidrug resistance is a major concern in the treatment of bacterial infections due to the reduced or missing response of microorganisms to the applied antimicrobial agents. One of the most important mechanisms of multidrug resistance is the increased expression of efflux pumps (EPs) that can extrude distinct classes of antibiotics from bacteria to the environment. In order to overcome this process, efflux pump inhibitors (EPIs) could be designed and applied alone or in combination with antibiotics as adjuvants. For this reason, the objective of this study was to investigate the antimicrobial and resistance modifying activity of natural compounds isolated from Cleistochlamys kirkii, fluorinated $\beta$-diketo phosphorus ylides and selenocompounds on different Gram-positive and Gram-negative strains. The effects of compounds on bacterial growth were determined by microdilution method. The EP inhibiting activity of compounds on the accumulation and/or efflux of the general EP substrate ethidium bromide was assessed by realtime fluorimetry on Escherichia coli, Salmonella Typhimurium and Staphylococcus aureus strains. The anti-biofilm effect of selenocompounds was investigated by crystal violet assay using S. Typhimurium 14028s strain. The combined effects of antibiotics (tetracycline and ciprofloxacin) and compounds were examined by minimum inhibitory concentration reduction assay or checkerboard microdilution method. The quorum sensing inhibition of natural compounds and phosphorus ylides was studied by agar diffusion method, furthermore the relative gene expression level of EP and/or quorum sensing genes were determined by reverse transcriptase quantitative polymerase chain reaction. Results showed that chamanetin (CK2) and dichamanetin (CK4) from $C$. kirkii showed synergism with antibiotics on methicillin sensitive $S$. aureus, all the natural compounds except isochamanetin (CK3) were able to inhibit the quorum sensing. The most potent representative of phosphorus ylides was 4,4,4-trifluoro-3-oxo-2(triphenylphosphoranylidene)butanal (PY4) and its effect was more pronounced on the AcrABTolC efflux system expressing E. coli strain. According to the results the methylketone selenoester (EDA9) had remarkable antibacterial activity against Gram-positive strains. The most selenocompounds were able to inhibit the biofilm formation of $S$. Typhimurium. The selenoanhydride (EDA1) and the meta-substituted benzene selenodiester (EDA4) were active inhibitors of the AcrAB-TolC system in E. coli AG100. These results suggested that natural compounds could be effective adjuvants in the antibiotic treatment of infections. Phosphorus ylides might be valuable EPI compounds to reverse efflux related multidrug resistance in bacteria and selenocompounds can be effective antibacterials and EPIs. 


\section{ÖSSZEFOGLALÁS}

A multidrog rezisztencia során az előzetesen alkalmazott antibakteriális szer hatástalanná válik, mely súlyos problémát okoz a bakteriális fertőzések terápiájában. A multidrog rezisztencia kialakulásának egyik legjelentősebb mechanizmusa az efflux pumpák (EPs) túltermelése, amelyek a különböző hatásmechanizmusú antibiotikumokat képesek a baktériumsejtből a környezetbe juttatni. Az efflux mechanizmusokhoz köthető rezisztencia leküzdéséhez fontos lenne olyan efflux pumpa gátló (EPI) vegyületek tervezése, melyek önmagukban vagy antibiotikummal kombinációban alkalmazhatóak a fertőzések kezelésében. A jelen disszertáció célja három vegyületcsoport (Cleistochlamys kirkii-böl izolált természetes vegyületek, foszfor-ilidek, illetve szelénvegyületek) antimikrobiális és rezisztencia visszafordító hatásának vizsgálata in vitro Gram-pozitív, illetve Gram-negatív baktérium modellek felhasználásával. A vegyületek antibakteriális hatását mikrodilúciós módszerrel határoztuk meg, az EP gátlást etídium-bromid akkumulációs, illetve efflux vizsgálattal tanulmányoztuk valós idejü fluoreszcencia méréssel Escherichia coli, Salmonella Typhimurium, illetve Staphylococcus aureus törzsek felhasználásával. A szelénvegyületek biofilm gátló aktivitását kristályibolyás festéssel határoztuk meg S. Typhimurium 14028s törzsön. A természetes vegyületeket és a szelénvegyületeket kombinációban vizsgáltuk antibiotikumokkal (ciprofloxacinnal és tetraciklinnel), valamint a foszfor-ilidek és a $C$. kirkii származékok quorum-sensing (QS) gátló hatását agardiffúziós módszerrel határoztuk meg. Mind a három vegyületcsoportból a leghatásosabb EP gátló aktivitással rendelkező vegyületek génexpresszióra gyakorolt hatását RT-qPCR reakcióval teszteltük. Eredményeink alapján elmondható, hogy a C. kirkii-ből izolált kamanetin (CK2) és dikamanetin (CK4) a kísérletben alkalmazott antibiotikumokkal szinergizmust mutatott a methicillin érzékeny $S$. aureus törzsön, továbbá az izokamanetint (CK3) kivéve a vegyületek hatékonyan gátolták a QS-et. A foszfor-ilidek közül a 4,4,4-trifluoro-3-oxo-2(trifenilfoszforanilidin)butanal (PY4) gátolta a leghatékonyabban az E. coli AcrAB-TolC efflux rendszerét. A metilketon szelenoészter (EDA9) a vizsgált Gram-pozitív törzseken jelentős antibakteriális hatással rendelkezett. A szelénvegyületek hatékonyan gátolták a $S$. Typhimurium 14028s biofilm képzését, illetve a ciklikus szelenoanhidrid (EDA1) és a meta-szubsztituált benzol szelenodiészter (EDA4) erősen gátolta az E. coli AG100 AcrAB-TolC rendszerét. A mérési eredményeink alapján megállapítható, hogy a $C$. kirkii-ből izolált vegyületek hatásosak lehetnek adjuvánsként, a foszfor-ilidek EPI vegyületekként, a szelénszármazékok pedig antibakteriális, illetve EPI vegyületként alkalmazva a bakteriális fertőzések kezelésében. 


\section{REFERENCES}

1. Gould, K. Antibiotics: from prehistory to the present day. J. Antimicrob. Chemother. 71, 572-575 (2016).

2. Lansdown, A. B. Silver in Health Care: Antimicrobial effects and safety in use. Curr. Probl. Dermatol. 33, 17-34 (2006).

3. Ventola, C. L. The antibiotic resistance crisis: part 1: causes and threats. $P$ T. 40, 277283 (2015).

4. Ferri, M., Ranucci, E., Romagnoli, P. \& Giaccone, V. Antimicrobial resistance: a global emerging threat to public health systems. Crit. Rev. Food Sci. Nutr. 57, 2857-2876 (2017).

5. Goossens, H., Ferech, M., Vander Stichele, R., Elseviers, M. \& ESAC Project Group. Outpatient antibiotic use in Europe and association with resistance: a cross-national database study. Lancet Lond. Engl. 365, 579-587 (2005).

6. Sun, L., Klein, E. Y. \& Laxminarayan, R. Seasonality and temporal correlation between community antibiotic use and resistance in the United States. Clin. Infect. Dis. 55, 687694 (2012).

7. Economou, V. \& Gousia, P. Agriculture and food animals as a source of antimicrobialresistant bacteria. Infect. Drug Resist. 8, 49-61 (2015).

8. Cabello, F. C. Heavy use of prophylactic antibiotics in aquaculture: a growing problem for human and animal health and for the environment. Environ. Microbiol. 8, 11371144 (2006).

9. von Wintersdorff, C. J. H. et al. Dissemination of antimicrobial resistance in microbial ecosystems through horizontal gene transfer. Front. Microbiol. 7, 173 (2016).

10. The European Centre for Disease Prevention and Control (ECDC). Surveillance of antimicrobial resistance in Europe. Annual report of the european antimicrobial resistance surveillance Network (EARS-Net). (2017).

11. O'Neill, J. Antimicrobial resistance: tackling a crisis for the health and wealth of nations. (2015). https://amr-review.org/

12. Centers for Disease Control and Prevention. Antibiotic resistance threats in the United States, 2013. (2013). https://www.cdc.gov/drugresistance/pdf/ar-threats-2013-508.pdf

13. Livermore, D. M. Bacterial resistance: origins, epidemiology, and impact. Clin. Infect. Dis. 36, S11-23 (2003).

14. Arzanlou, M., Chai, W. C. \& Venter, H. Intrinsic, adaptive and acquired antimicrobial resistance in Gram-negative bacteria. Essays Biochem. 61, 49-59 (2017).

15. Davies, J. \& Davies, D. Origins and evolution of antibiotic resistance. Microbiol. Mol. Biol. Rev. 74, 417-433 (2010).

16. Blair, J. M. A., Webber, M. A., Baylay, A. J., Ogbolu, D. O. \& Piddock, L. J. V. Molecular mechanisms of antibiotic resistance. Nat. Rev. Microbiol. 13, 42-51 (2015).

17. Webber, M. A. \& Piddock, L. J. V. The importance of efflux pumps in bacterial antibiotic resistance. J. Antimicrob. Chemother. 51, 9-11 (2003).

18. Lewis, K. Persister cells. Annu. Rev. Microbiol. 64, 357-372 (2010). 
19. Zgurskaya, H. I., Löpez, C. A. \& Gnanakaran, S. Permeability barrier of Gram-negative cell envelopes and approaches to bypass it. ACS Infect. Dis. 1, 512-522 (2015).

20. González-Bello, C. Antibiotic adjuvants - A strategy to unlock bacterial resistance to antibiotics. Bioorg. Med. Chem. Lett. 27, 4221-4228 (2017).

21. Furuya, E. Y. \& Lowy, F. D. Antimicrobial-resistant bacteria in the community setting. Nat. Rev. Microbiol. 4, 36-45 (2006).

22. Heuer, H. \& Smalla, K. Horizontal gene transfer between bacteria. Environ. Biosafety Res. 6, 3-13 (2007).

23. de Vries, J. \& Wackernagel, W. Integration of foreign DNA during natural transformation of Acinetobacter sp. by homology-facilitated illegitimate recombination. Proc. Natl. Acad. Sci. U. S. A. 99, 2094-2099 (2002).

24. Thomas, C. M. \& Nielsen, K. M. Mechanisms of, and barriers to, horizontal gene transfer between bacteria. Nat. Rev. Microbiol. 3, 711-721 (2005).

25. Unemo, M. et al. High-level cefixime- and ceftriaxone-resistant Neisseria gonorrhoeae in France: novel penA mosaic allele in a successful international clone causes treatment failure. Antimicrob. Agents Chemother. 56, 1273-1280 (2012).

26. Brown-Jaque, M., Calero-Cáceres, W. \& Muniesa, M. Transfer of antibiotic-resistance genes via phage-related mobile elements. Plasmid 79, 1-7 (2015).

27. Colomer-Lluch, M., Imamovic, L., Jofre, J. \& Muniesa, M. Bacteriophages carrying antibiotic resistance genes in fecal waste from cattle, pigs, and poultry. Antimicrob. Agents Chemother. 55, 4908-4911 (2011).

28. Hayes F. The horizontal gene pool: bacterial plasmids and gene spread. Editor: Thomas CM. 86, 251-252 (Harwood Academic Publishers, 2000).

29. Guglielmini, J., de la Cruz, F. \& Rocha, E. P. C. Evolution of conjugation and type IV secretion systems. Mol. Biol. Evol. 30, 315-331 (2013).

30. Holmes, A. H. et al. Understanding the mechanisms and drivers of antimicrobial resistance. Lancet Lond. Engl. 387, 176-187 (2016).

31. Dhanji, H. et al. Molecular epidemiology of fluoroquinolone-resistant ST131 Escherichia coli producing CTX-M extended-spectrum beta-lactamases in nursing homes in Belfast, UK. J. Antimicrob. Chemother. 66, 297-303 (2011).

32. Walsh, T. R., Weeks, J., Livermore, D. M. \& Toleman, M. A. Dissemination of NDM-1 positive bacteria in the New Delhi environment and its implications for human health: an environmental point prevalence study. Lancet Infect. Dis. 11, 355-362 (2011).

33. Borges, A. et al. New perspectives on the use of phytochemicals as an emergent strategy to control bacterial infections including biofilms. Molecules 21, pii: E877 (2016).

34. Wright, G. D. Molecular mechanisms of antibiotic resistance. Chem. Commun. 47, 4055 (2011).

35. Alav, I., Sutton, J. M. \& Rahman, K. M. Role of bacterial efflux pumps in biofilm formation. J. Antimicrob. Chemother. 73, 2003-2020 (2018).

36. Alcalde-Rico, M., Hernando-Amado, S., Blanco, P. \& Martínez, J. L. Multidrug efflux pumps at the crossroad between antibiotic resistance and bacterial virulence. Front. Microbiol. 7, 1483 (2016). 
37. Dockrell, H. M., Goering, R. V., Roitt, I., Wakelin, D., Zuckerman, M. Attacking the enemy: antimicrobial agents and chemotherapy. In: Medical Microbiology. Editors: Mims, C., Dockrell, H. M., Goering, R. V., Roitt, I., Wakelin, D., Zuckerman, M. 473-507 (Elsevier Mosby) (2004).

38. Kapoor, G., Saigal, S. \& Elongavan, A. Action and resistance mechanisms of antibiotics: A guide for clinicians. J. Anaesthesiol. Clin. Pharmacol. 33, 300 (2017).

39. Maurice, F. et al. Enzyme structural plasticity and the emergence of broad-spectrum antibiotic resistance. EMBO Rep. 9, 344-349 (2008).

40. Alekshun, M. N. \& Levy, S. B. Molecular mechanisms of antibacterial multidrug resistance. Cell 128, 1037-1050 (2007).

41. Doi, Y., Iovleva, A. \& Bonomo, R. A. The ecology of extended-spectrum $\beta$-lactamases (ESBLs) in the developed world. J. Travel Med. 24, S44-S51 (2017).

42. Tolmasky, M., E. Bacterial resistance to aminoglycosides and beta-lactams: the Tn1331 transposon paradigm. Front. Biosci. 5, D20-29 (1999).

43. Hiramatsu, K., Cui, L., Kuroda, M. \& Ito, T. The emergence and evolution of methicillin-resistant Staphylococcus aureus. Trends Microbiol. 9, 486-493 (2001).

44. Fernandez, L. \& Hancock, R. E. W. Adaptive and mutational resistance: role of porins and efflux pumps in drug resistance. Clin. Microbiol. Rev. 25, 661-681 (2012).

45. Masi, M., Winterhalter, M. \& Pagès, J.-M. Outer membrane porins. In: Bacterial cell walls and membranes. Editor: Kuhn, A. 92, 79-123 (Springer International Publishing), (2019).

46. Pagès, J.M., James, C. E. \& Winterhalter, M. The porin and the permeating antibiotic: a selective diffusion barrier in Gram-negative bacteria. Nat. Rev. Microbiol. 6, 893-903 (2008).

47. Giedraitienè, A., Vitkauskienè, A., Naginienè, R. \& Pavilonis, A. Antibiotic resistance mechanisms of clinically important bacteria. Medicina 47, 137-146 (2011).

48. Nikaido, H. Multidrug resistance in bacteria. Annu. Rev. Biochem. 78, 119-146 (2009).

49. Li, X.-Z. \& Nikaido, H. Efflux-mediated drug resistance in bacteria: an update. Drugs 69, 1555-1623 (2009).

50. Amaral, L., Martins, A., Spengler, G. \& Molnar, J. Efflux pumps of Gram-negative bacteria: what they do, how they do it, with what and how to deal with them. Front. Pharmacol. 4, 168 (2014).

51. Poole, K. Efflux pumps as antimicrobial resistance mechanisms. Ann. Med. 39, 162-176 (2007).

52. Higgins, C. F. Multiple molecular mechanisms for multidrug resistance transporters. Nature 446, 749-757 (2007).

53. Hassan, K. A., Liu, Q., Henderson, P. J. F. \& Paulsen, I. T. Homologs of the Acinetobacter baumannii AceI transporter represent a new family of bacterial multidrug efflux systems. MBio. 6, (2015).

54. Schindler, B. D. \& Kaatz, G. W. Multidrug efflux pumps of Gram-positive bacteria. Drug Resist. Updat. 27, 1-13 (2016).

55. Mousa, J. J. \& Bruner, S. D. Structural and mechanistic diversity of multidrug transporters. Nat. Prod. Rep. 33, 1255-1267 (2016). 
56. Lubelski, J., Konings, W. N. \& Driessen, A. J. M. Distribution and physiology of ABCtype transporters contributing to multidrug resistance in bacteria. Microbiol. Mol. Biol. Rev. 71, 463-476 (2007).

57. Langton, K. P., Henderson, P. J. F. \& Herbert, R. B. Antibiotic resistance: multidrug efflux proteins, a common transport mechanism? Nat. Prod. Rep. 22, 439-451 (2005).

58. Kim, J. et al. Subnanometre-resolution electron cryomicroscopy structure of a heterodimeric ABC exporter. Nature 517, 396-400 (2015).

59. Hollenstein, K., Frei, D. C. \& Locher, K. P. Structure of an ABC transporter in complex with its binding protein. Nature 446, 213-216 (2007).

60. Hohl, M. et al. Structural basis for allosteric cross-talk between the asymmetric nucleotide binding sites of a heterodimeric ABC exporter. Proc. Natl. Acad. Sci. U. S. A. 111, 11025-11030 (2014).

61. Lee, E.-W., Huda, M. N., Kuroda, T., Mizushima, T. \& Tsuchiya, T. EfrAB, an ABC multidrug efflux pump in Enterococcus faecalis. Antimicrob. Agents Chemother. 47, 3733-3738 (2003).

62. Kobayashi, N., Nishino, K. \& Yamaguchi, A. Novel macrolide-specific ABC-type efflux transporter in Escherichia coli. J. Bacteriol. 183, 5639-5644 (2001).

63. Boncoeur, E. et al. PatA and PatB form a functional heterodimeric ABC multidrug efflux transporter responsible for the resistance of Streptococcus pneumoniae to fluoroquinolones. Biochemistry 51, 7755-7765 (2012).

64. van Veen, H. W., Margolles, A., Müller, M., Higgins, C. F. \& Konings, W. N. The homodimeric ATP-binding cassette transporter LmrA mediates multidrug transport by an alternating two-site (two-cylinder engine) mechanism. EMBO J. 19, 2503-2514 (2000).

65. Du, D., van Veen, H. W., Murakami, S., Pos, K. M. \& Luisi, B. F. Structure, mechanism and cooperation of bacterial multidrug transporters. Curr. Opin. Struct. Biol. 33, 76-91 (2015).

66. Kuroda, T. \& Tsuchiya, T. Multidrug efflux transporters in the MATE family. Biochim. Biophys. Acta 1794, 763-768 (2009).

67. Jin, Y., Nair, A. \& van Veen, H. W. Multidrug transport protein NorM from Vibrio cholerae simultaneously couples to sodium- and proton-motive force. J. Biol. Chem. 289, 14624-14632 (2014).

68. Long, F., Rouquette-Loughlin, C., Shafer, W. M. \& Yu, E. W. Functional cloning and characterization of the multidrug efflux pumps NorM from Neisseria gonorrhoeae and YdhE from Escherichia coli. Antimicrob. Agents Chemother. 52, 3052-3060 (2008).

69. $\mathrm{Xu}, \mathrm{X}$. J. et al. Molecular cloning and characterization of the HmrM multidrug efflux pump from Haemophilus influenzae Rd. Microbiol. Immunol. 47, 937-943 (2003).

70. He, G. X. et al. An $\mathrm{H}^{+}$-coupled multidrug efflux pump, PmpM, a member of the MATE family of transporters, from Pseudomonas aeruginosa. J. Bacteriol. 186, 262-265 (2004).

71. Banchs, C., Poulos, S., Nimjareansuk, W. S., Joo, Y. E. \& Faham, S. Substrate binding to the multidrug transporter MepA. Biochim. Biophys. Acta 1838, 2539-2546 (2014).

72. Putman, M., van Veen, H. W. \& Konings, W. N. Molecular properties of bacterial multidrug transporters. Microbiol. Mol. Biol. Rev. 64, 672-693 (2000). 
73. Law, C. J., Maloney, P. C. \& Wang, D. N. Ins and outs of major facilitator superfamily antiporters. Annu. Rev. Microbiol. 62, 289-305 (2008).

74. Spengler, G., Kincses, A., Gajdács, M. \& Amaral, L. New roads leading to old destinations: efflux pumps as targets to reverse multidrug resistance in bacteria. Molecules 22, E468 (2017).

75. Tanabe, M. et al. The multidrug resistance efflux complex, EmrAB from Escherichia coli forms a dimer in vitro. Biochem. Biophys. Res. Commun. 380, 338-342 (2009).

76. Xianwei, T., Diannan, L. \& Boxiong, W. Substrate transport pathway inside outward open conformation of EmrD: a molecular dynamics simulation study. Mol. Biosyst. 12, 2634-2641 (2016).

77. Edgar, R. \& Bibi, E. MdfA, an Escherichia coli multidrug resistance protein with an extraordinarily broad spectrum of drug recognition. J. Bacteriol. 179, 2274-2280 (1997)

78. Adler, J. \& Bibi, E. Determinants of substrate recognition by the Escherichia coli multidrug transporter MdfA identified on both sides of the membrane. J. Biol. Chem. 279, 8957-8965 (2004).

79. Bhaskar, B. V., Babu, T. M. C., Reddy, N. V. \& Rajendra, W. Homology modeling, molecular dynamics, and virtual screening of NorA efflux pump inhibitors of Staphylococcus aureus. Drug Des. Devel. Ther. 10, 3237-3252 (2016).

80. Paulsen, I. T., Brown, M. H., Littlejohn, T. G., Mitchell, B. A. \& Skurray, R. A. Multidrug resistance proteins QacA and QacB from Staphylococcus aureus: membrane topology and identification of residues involved in substrate specificity. Proc. Natl. Acad. Sci. U. S. A. 93, 3630-3635 (1996).

81. Floyd, J. L., Smith, K. P., Kumar, S. H., Floyd, J. T. \& Varela, M. F. LmrS is a multidrug efflux pump of the major facilitator superfamily from Staphylococcus aureus. Antimicrob. Agents Chemother. 54, 5406-5412 (2010).

82. Roth, A. \& Govaerts, C. LmrP from Lactoccoccus lactis: a tractable model to understand secondary multidrug transport in MFS. Res. Microbiol. 169, 468-477 (2018).

83. Piddock, L. J., Johnson, M. M., Simjee, S. \& Pumbwe, L. Expression of efflux pump gene pmrA in fluoroquinolone-resistant and -susceptible clinical isolates of Streptococcus pneumoniae. Antimicrob. Agents Chemother. 46, 808-812 (2002).

84. Kermani, A. A., Macdonald, C. B., Gundepudi, R. \& Stockbridge, R. B. Guanidinium export is the primal function of SMR family transporters. Proc. Natl. Acad. Sci. U. S. A. 115, 3060-3065 (2018).

85. Nasie, I., Steiner-Mordoch, S. \& Schuldiner, S. New substrates on the block: clinically relevant resistances for EmrE and homologues. J. Bacteriol. 194, 6766-6770 (2012).

86. Schuldiner, S., Lebendiker, M. \& Yerushalmi, H. EmrE, the smallest ion-coupled transporter, provides a unique paradigm for structure-function studies. J. Exp. Biol. 200, 335-341 (1997).

87. Kikukawa, T., Miyauchi, S., Araiso, T., Kamo, N. \& Nara, T. Anti-parallel membrane topology of two components of EbrAB, a multidrug transporter. Biochem. Biophys. Res. Commun. 358, 1071-1075 (2007). 
88. Seier-Petersen, M. A., Nielsen, L. N., Ingmer, H., Aarestrup, F. M. \& Agersø, Y. Biocide susceptibility of Staphylococcus aureus CC398 and CC30 isolates from pigs and identification of the biocide resistance genes, qacG and qacC. Microb. Drug Resist. 21, 527-536 (2015).

89. Sarkar, S. K., Bhattacharyya, A. \& Mandal, S. M. YnfA, a SMR family efflux pump is abundant in Escherichia coli isolates from urinary infection. Indian J. Med. Microbiol. 33, 139-142 (2015).

90. Hassan, K. A. et al. Pacing across the membrane: the novel PACE family of efflux pumps is widespread in Gram-negative pathogens. Res. Microbiol. 169, 450-454 (2018).

91. Daury, L. et al. Tripartite assembly of RND multidrug efflux pumps. Nat. Commun. 7, 10731 (2016).

92. Nikaido, H. \& Takatsuka, Y. Mechanisms of RND multidrug efflux pumps. Biochim. Biophys. Acta 1794, 769-781 (2009).

93. Yang, L. et al. RND transporters protect Corynebacterium glutamicum from antibiotics by assembling the outer membrane. Microbiologyopen 3, 484-496 (2014).

94. Alnaseri, H. et al. Inducible expression of a resistance-nodulation-division-type efflux pump in Staphylococcus aureus provides resistance to linoleic and arachidonic acids. $J$. Bacteriol. 197, 1893-1905 (2015).

95. Kim, J. S. et al. Structure of the tripartite multidrug efflux pump AcrAB-TolC suggests an alternative assembly mode. Mol. Cells 38, 180-186 (2015).

96. Li, X.-Z., Plésiat, P. \& Nikaido, H. The challenge of efflux-mediated antibiotic resistance in Gram-negative bacteria. Clin. Microbiol. Rev. 28, 337-418 (2015).

97. Venter, H., Mowla, R., Ohene-Agyei, T. \& Ma, S. RND-type drug efflux pumps from Gram-negative bacteria: molecular mechanism and inhibition. Front. Microbiol. 6, 377 (2015).

98. Hobbs, E. C., Yin, X., Paul, B. J., Astarita, J. L. \& Storz, G. Conserved small protein associates with the multidrug efflux pump AcrB and differentially affects antibiotic resistance. Proc. Natl. Acad. Sci. U. S. A. 109, 16696-16701 (2012).

99. Du, D. et al. Structure of the AcrAB-TolC multidrug efflux pump. Nature 509, 512-515 (2014).

100. Piddock, L. J. Multidrug-resistance efflux pumps - not just for resistance. Nat. Rev. Microbiol. 4, 629-636 (2006).

101. Ruggerone, P., Murakami, S., Pos, K. M. \& Vargiu, A. V. RND efflux pumps: structural information translated into function and inhibition mechanisms. Curr. Top. Med. Chem. 13, 3079-3100 (2013).

102. Nikaido, H. \& Zgurskaya, H. I. AcrAB and related multidrug efflux pumps of Escherichia coli. J. Mol. Microbiol. Biotechnol. 3, 215-218 (2001).

103. Pan, Y.-P., Xu, Y.-H., Wang, Z.-X., Fang, Y.-P. \& Shen, J.-L. Overexpression of MexAB-OprM efflux pump in carbapenem-resistant Pseudomonas aeruginosa. Arch. Microbiol. 198, 565-571 (2016).

104. Terzi, H. A., Kulah, C. \& Ciftci, I. H. The effects of active efflux pumps on antibiotic resistance in Pseudomonas aeruginosa. World J. Microbiol. Biotechnol. 30, 2681-2687 (2014) 
105. Rosenberg, E. Y., Ma, D. \& Nikaido, H. AcrD of Escherichia coli is an aminoglycoside efflux pump. J. Bacteriol. 182, 1754-1756 (2000).

106. Srinivasan, V. B., Singh, B. B., Priyadarshi, N., Chauhan, N. K. \& Rajamohan, G. Role of novel multidrug efflux pump involved in drug resistance in Klebsiella pneumoniae. PLoS One 9, e96288 (2014).

107. Hagman, K. E. et al. The MtrD protein of Neisseria gonorrhoeae is a member of the resistance-nodulation-division protein family constituting part of an efflux system. Microbiol. Read. Engl. 143, 2117-2125 (1997).

108. Wang, Z. et al. An allosteric transport mechanism for the AcrAB-TolC multidrug efflux pump. Elife 6, e24905 (2017).

109. Suresh, M. K., Biswas, R. \& Biswas, L. An update on recent developments in the prevention and treatment of Staphylococcus aureus biofilms. Int. J. Med. Microbiol. 309, 1-12 (2019).

110. Jamal, M. et al. Bacterial biofilm and associated infections. J. Chin. Med. Assoc. 81, 711 (2018).

111. Steenackers, H., Hermans, K., Vanderleyden, J. \& De Keersmaecker, S. C. J. Salmonella biofilms: An overview on occurrence, structure, regulation and eradication. Food Res. Int. 45, 502-531 (2012).

112. del Pozo, J. L. \& Patel, R. The challenge of treating biofilm-associated bacterial infections. Clin. Pharmacol. Ther. 82, 204-209 (2007).

113. Soto, S. M. Role of efflux pumps in the antibiotic resistance of bacteria embedded in a biofilm. Virulence 4, 223-229 (2013).

114. Renner, L. D. \& Weibel, D. B. Physicochemical regulation of biofilm formation. MRS Bull. 36, 347-355 (2011).

115. Flemming, H. C., Neu, T. R. \& Wozniak, D. J. The EPS matrix: the 'house of biofilm cells'. J. Bacteriol. 189, 7945-7947 (2007).

116. Rabin, N. et al. Biofilm formation mechanisms and targets for developing antibiofilm agents. Future Med. Chem. 7, 493-512 (2015).

117. Sauer, K. The genomics and proteomics of biofilm formation. Genome Biol. 4, 219 (2003).

118. Wu, H., Moser, C., Wang, H.-Z., Høiby, N. \& Song, Z. J. Strategies for combating bacterial biofilm infections. Int. J. Oral Sci. 7, 1-7 (2015).

119. Suci, P. A., Mittelman, M. W., Yu, F. P. \& Geesey, G. G. Investigation of ciprofloxacin penetration into Pseudomonas aeruginosa biofilms. Antimicrob. Agents Chemother. 38, 2125-2133 (1994).

120. Del Pozo, J. L. Biofilm-related disease. Expert Rev. Anti Infect. Ther. 16, 51-65 (2018).

121. Molin, S. \& Tolker-Nielsen, T. Gene transfer occurs with enhanced efficiency in biofilms and induces enhanced stabilisation of the biofilm structure. Curr. Opin. Biotechnol. 14, 255-261 (2003).

122. Zhang, L. \& Mah, T. F. Involvement of a novel efflux system in biofilm-specific resistance to antibiotics. J. Bacteriol. 190, 4447-4452 (2008).

123. Lyon, G. J. \& Muir, T. W. Chemical signaling among bacteria and its inhibition. Chem. Biol. 10, 1007-1021 (2003). 
124. Lipa, P., Kozieł, M. \& Janczarek, M. Quorum sensing in Gram-negative bacteria: signal molecules, inhibitors and their potential therapeutic application. Postepy Biochem. 63, 242-260 (2017).

125. Brunel, A.-S. \& Guery, B. Multidrug resistant (or antimicrobial-resistant) pathogens alternatives to new antibiotics? Swiss Med. Wkly. 147, w14553 (2017).

126. Papenfort, K. \& Bassler, B. L. Quorum sensing signal-response systems in Gramnegative bacteria. Nat. Rev. Microbiol. 14, 576-588 (2016).

127. Kanamaru, K., Kanamaru, K., Tatsuno, I., Tobe, T. \& Sasakawa, C. SdiA, an Escherichia coli homologue of quorum-sensing regulators, controls the expression of virulence factors in enterohaemorrhagic Escherichia coli O157:H7. Mol. Microbiol. 38, 805-816 (2000).

128. Tavío, M. M. et al. Quorum-sensing regulator sdiA and marA overexpression is involved in in vitro-selected multidrug resistance of Escherichia coli. J. Antimicrob. Chemother. 65, 1178-1186 (2010).

129. Sweeney, L. C. Antibiotic resistance in general dental practice - a cause for concern? J. Antimicrob. Chemother. 53, 567-576 (2004).

130. Upadhyay, A. et al. Inhibiting microbial toxins using plant-derived compounds and plant extracts. Medicines 2, 186-211 (2015).

131. Savoia, D. Plant-derived antimicrobial compounds: alternatives to antibiotics. Future Microbiol. 7, 979-990 (2012).

132. Stavri, M., Piddock, L. J. \& Gibbons, S. Bacterial efflux pump inhibitors from natural sources. J. Antimicrob. Chemother. 59, 1247-1260 (2007).

133. Neyfakh, A. A., Bidnenko, V. E. \& Chen, L. B. Efflux-mediated multidrug resistance in Bacillus subtilis: similarities and dissimilarities with the mammalian system. Proc. Natl. Acad. Sci. 88, 4781-4785 (1991).

134. Khan, I. A., Mirza, Z. M., Kumar, A., Verma, V. \& Qazi, G. N. Piperine, a phytochemical potentiator of ciprofloxacin against Staphylococcus aureus. Antimicrob. Agents Chemother. 50, 810-812 (2006).

135. Garvey, M. I., Rahman, M. M., Gibbons, S. \& Piddock, L. J. V. Medicinal plant extracts with efflux inhibitory activity against Gram-negative bacteria. Int. J. Antimicrob. Agents 37, 145-151 (2011).

136. Mouwakeh, A. et al. Nigella sativa essential oil and its bioactive compounds as resistance modifiers against Staphylococcus aureus. Phytother. Res. 33, 1010-1018 (2019).

137. Verzár, R. \& Petri, G. Medicinal plants in Mozambique and their popular use. J. Ethnopharmacol. 19, 67-80 (1987).

138. Samwel, S. et al. Cleistenolide and cleistodienol: novel bioactive constituents of Cleistochlamys kirkii. Nat. Prod. Commun. 2, 737-741 (2007).

139. Pereira, F. et al. Cleistenolide and cleistodienol: novel bioactive constituents of Cleistochlamys kirkii. chemical constituents: antibacterial activity and synergistic effects against resistant Staphylococcus aureus strains. J. Ethnopharmacol. 178, 180187 (2016). 
140. El-Batta, A. et al. Wittig reactions in water media employing stabilized ylides with aldehydes. Synthesis of $\alpha, \beta$-unsaturated esters from mixing aldehydes, alphabromoesters, and $\mathrm{Ph}_{3} \mathrm{P}$ in aqueous $\mathrm{NaHCO}_{3}$. J. Org. Chem. 72, 5244-5259 (2007).

141. Spengler, G. et al. Fluorinated $\beta$-diketo phosphorus ylides are novel inhibitors of the ABCB1 efflux pump of cancer cells. Anticancer Res. 35, 5915-5919 (2015).

142. Lobanov, A. V., Hatfield, D. L. \& Gladyshev, V. N. Eukaryotic selenoproteins and selenoproteomes. Biochim. Biophys. Acta 1790, 1424-1428 (2009).

143. Vila, J. et al. Escherichia coli: an old friend with new tidings. FEMS Microbiol. Rev. 40, 437-463 (2016).

144. Tong, S. Y. C., Davis, J. S., Eichenberger, E., Holland, T. L. \& Fowler, V. G. Staphylococcus aureus infections: epidemiology, pathophysiology, clinical manifestations, and management. Clin. Microbiol. Rev. 28, 603-661 (2015).

145. Mancini, A. et al. Retrospective analysis of nosocomial infections in an Italian tertiary care hospital. New Microbiol. 39, 197-205 (2016).

146. Sonkusre, P. \& Singh Cameotra, S. Biogenic selenium nanoparticles inhibit Staphylococcus aureus adherence on different surfaces. Colloids Surf. B Biointerfaces 136, 1051-1057 (2015).

147. Kumar, B. S. et al. Anti-ulcer and antimicrobial activities of sodium selenite against Helicobacter pylori: in vitro and in vivo evaluation. Scand. J. Infect. Dis. 42, 266-274 (2010).

148. Tran, P. A. \& Webster, T. J. Antimicrobial selenium nanoparticle coatings on polymeric medical devices. Nanotechnology 24, 155101 (2013).

149. Domínguez-Álvarez, E. et al. Identification of selenocompounds with promising properties to reverse cancer multidrug resistance. Bioorg. Med. Chem. Lett. 26, 28212824 (2016).

150. Gajdács, M. et al. Selenoesters and selenoanhydrides as novel multidrug resistance reversing agents: a confirmation study in a colon cancer MDR cell line. Bioorg. Med. Chem. Lett. 27, 797-802 (2017).

151. Domínguez-Álvarez, E. et al. Synthesis and antiproliferative activity of novel selenoester derivatives. Eur. J. Med. Chem. 73, 153-166 (2014).

152. Smith, H. E. \& Blair, J. M. A. Redundancy in the periplasmic adaptor proteins AcrA and AcrE provides resilience and an ability to export substrates of multidrug efflux. $J$. Antimicrob. Chemother. 69, 982-987 (2014).

153. Varga, Z. G. et al. Inhibition of quorum sensing and efflux pump system by trifluoromethyl ketone proton pump inhibitors. In Vivo 26, 277-285 (2012).

154. Clinical and Laboratory Standards Institute (CLSI). Performance standards for antimicrobial susceptibility testing. $28^{\text {th }}$ ed. CLSI supplement M100. (2018).

155. Viveiros, M. et al. Demonstration of intrinsic efflux activity of Escherichia coli K-12 AG100 by an automated ethidium bromide method. Int. J. Antimicrob. Agents 31, 458462 (2008).

156. Wolfart, K. et al. Synergistic interaction between proton pump inhibitors and resistance modifiers: promoting effects of antibiotics and plasmid curing. In Vivo 20, 367-372 (2006). 
157. Chou, T. C. Theoretical basis, experimental design, and computerized simulation of synergism and antagonism in drug combination studies. Pharmacol. Rev. 58, 621-681 (2006).

158. Couto, I., Costa, S. S., Viveiros, M., Martins, M. \& Amaral, L. Efflux-mediated response of Staphylococcus aureus exposed to ethidium bromide. J. Antimicrob. Chemother. 62, 504-513 (2008).

159. Viveiros, M. et al. Antibiotic stress, genetic response and altered permeability of E. coli. PloS One 2, e365 (2007).

160. Livak, K. J. \& Schmittgen, T. D. Analysis of relative gene expression data using realtime quantitative PCR and the $2^{-\Delta \Delta C}$ T method. Methods 25, 402-408 (2001).

161. Ledda, A. et al. Re-emergence of methicillin susceptibility in a resistant lineage of Staphylococcus aureus. J. Antimicrob. Chemother. 72, 1285-1288 (2017).

162. Spengler, G., Gajdács, M., Marć, M. A., Domínguez-Álvarez, E. \& Sanmartín, C. Organoselenium compounds as novel adjuvants of chemotherapy drugs-a promising approach to fight cancer drug resistance. Molecules 24, e336 (2019).

163. Grela, E., Kozłowska, J. \& Grabowiecka, A. Current methodology of MTT assay in bacteria - A review. Acta Histochem. 120, 303-311 (2018). 


\section{ACKNOWLEDGEMENTS}

I would like to express my deep and sincere gratitude to my supervisor, Dr. Gabriella Spengler for the opportunity to work in her research group and for opening the world to me. I am grateful to her for introducing me to the scientific research, for her excellent support and encouragement.

I would like to thank Dr. Katalin Burián, chair of the Department of Medical Microbiology and Immunobiology, for the possibility to work at the department.

I am extremly grateful to our collaborators Dr. Enrique Domínguez-Álvarez, Prof. Dr. Carmen Sanmartín, Prof. Dr. Maria-José U. Ferreira and Prof. Dr. Masami Kawase for providing us compounds for biological evaluation, furthermore their help and support resulted in fruitful scientific collaborations, projects and research grants.

I would like to give my special thanks to Mrs Anikó Vigyikánné Váradi for her technical assistance. I am grateful to Mrs Györgyi Müllerné Deák for the help with measuring the concentration of RNA.

I would like to thank all undergraduate students working in our research group who helped me during my studies.

I am grateful to all the members of the department for their support and for creating a pleasant working environment during my $\mathrm{Ph} . \mathrm{D}$ studies.

I am likewise grateful to Dr. Jessica M. A. Blair and Dr. Helen McNeil for the help with the biofilm and efflux assays at the University of Birmingham.

I would like to thank to Dr. Márió Gajdács for the help in naming compounds.

I am deeply grateful to my best friend Dr. Tímea Mosolygó and my friends Márta BozókiNové, Dóra Kovács, Csilla Abonyi and Dr. Anita Varga-Bogdanov for their selfless help, encouragment and friendship.

Lastly, I feel a deep sense of gratitude to my parents, my sisters and my boyfriend for their love, patience and encouragement. 


\section{FINANCIAL SUPPORT}

The work on which this thesis was based on was supported by the following organizations and grants:

- New National Excellence Program of the Ministry of Human Capacities (ÚNKP-17-3; ÚNKP-18-3)

- Tempus Public Foundation: Campus mundi student mobility, short study grant

- Talent Scholarship and Excellence List of the University of Szeged (2016/2017: Bronze level; 2017/2018: Gold level)

- Travel Award of the European Society of Clinical Microbiology and Infectious Diseases

- SZTE ÁOK-KKA 2018/270-62-2 of the University of Szeged, Faculty of Medicine, Hungary: Selenium derivatives as novel promising antimicrobial agents

- GINOP-2.3.2-15-2016-00012: New ways in natural medicine-based drug research: System-metabolomic approaches to screen for bioactive terpenoids of plant and microbial origin

- 2019-2021: Hungarian-Portuguese Intergovernmental S\&T Cooperation Programme. Title: Plant-derived compounds as anticancer agents: a promising approach for overcoming multidrug resistance 


\section{APPENDIX}

Appendix 1 IUPAC names of the P-ylides compounds

PY1: 4,4,4-trifluoro-3-oxo-2-(triphenylphosphoranylidene)butanenitrile

PY2: 1,1,1-trifluoro-3-oxo-1-methoxy-3-(triphenylphosphoranylidene)propane-2-one

PY3: trifluoro-1-phenyl-2-(triphenylphosphoranylidene)butane-1,3-dione

PY4: 4,4,4-trifluoro-3-oxo-2-(triphenylphosphoranylidene)butanal

PY5: 1,1,1-trifluoro-3-(triphenylphosphoranylidene)pentane-2,4-dione

PY6: ethyl-4,4,4-trifluoro-3-oxo-2-(triphenylphosphoranylidene)butanoate

PY7: 4,4,5,5,5-pentafluoro-1-phenyl-2-(triphenylphosphoranylidene)pentane-1,3-dione

PY8: 4,4,5,5,6,6,6-heptafluoro-1-phenyl-2-(triphenylphosphoranylidene)hexane-1,3-dione PY9: 3-oxo-2-(triphenylphosphoranylidene)butanenitrile

P10: 2-(triphenylphosphoranylidene)butanenitrile

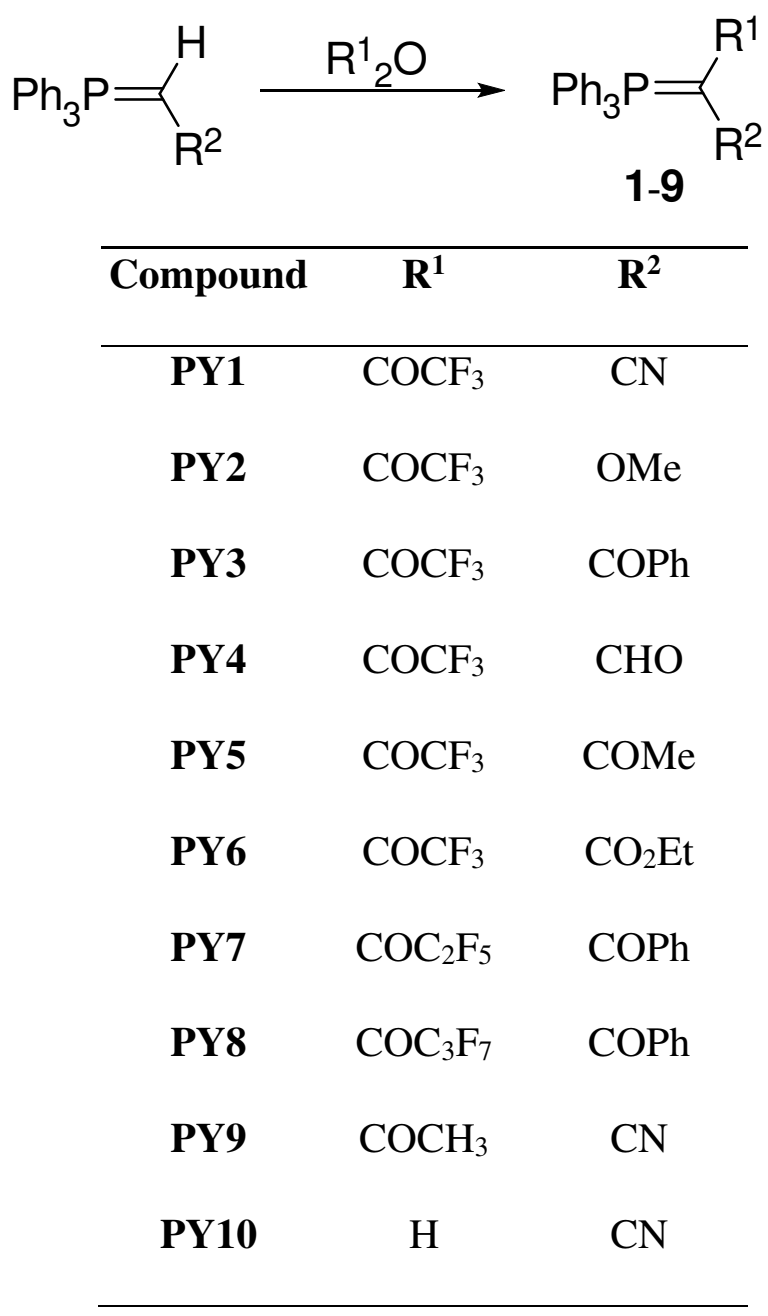

Appendix 2 Structures of P-ylides (PY1-10) 
Appendix 3 IUPAC names of the selenocompounds

EDA1: Benzo[c]selenophen-1,3-dione (cyclic selenoanhidride)

EDA2: Dimethyl thiophene-2,5-dicarboselenoate (thiophene selenodiester)

EDA3: Dimethyl pyridine-2,6-dicarboselenoate (pyridine selenodiester)

EDA4: Dimethyl benzene-1,3-dicarboselenoate (meta-substituted benzene selenodiester)

EDA5: Dimethyl benzene-1,4-dicarboselenoate (para-substituted benzene selenodiester)

EDA6: Carbamoylmethyl benzoselenoate (carbamoylmethyl selenoester)

EDA7: Methoxycarbonylmethyl p-chlorobenzoselenoate (methoxycarbonylmethyl selenoester)

EDA8: Phenoxycarbonylmethyl benzoselenoate (phenoxycarbonyl selenoester)

EDA9: 2-Oxopropyl 4-chlorobenzoselenoate (methylketone selenoester)

EDA10: 3,3-Dimethyl-2-oxobutyl 4-chlorobenzoselenoate (chloro-substituted tertbutylketone selenoester)

EDA11: 3,3-Dimethyl-2-oxobutyl 3,5-dimethoxybenzoselenoate (dimethoxy-substituted tertbutylketone selenoester)<smiles>O=C1[Se]C(=O)c2ccccc21</smiles><smiles></smiles>

I. Cyclic selenoanhydride (EDA1)

II. Selenoesters (EDA2-11)

\begin{tabular}{ccccc}
\hline Compound & $\mathbf{R}^{\mathbf{1}}$ & $\mathbf{X}$ & $\mathbf{n}$ & $\mathbf{R}^{\mathbf{2}}$ \\
\hline EDA1 & - & - & - & - \\
EDA2 & $5-\mathrm{COSeCH}_{3}$ & $\mathrm{~S}$ & 0 & $-\mathrm{CH}_{3}$ \\
EDA3 & $6-\mathrm{COSeCH}_{3}$ & $\mathrm{~N}$ & 1 & $-\mathrm{CH}_{3}$ \\
EDA4 & $3-\mathrm{COSeCH}_{3}$ & $\mathrm{C}$ & 1 & $-\mathrm{CH}_{3}$ \\
EDA5 & $4-\mathrm{COSeCH}_{3}$ & $\mathrm{C}$ & 1 & $-\mathrm{CH}_{3}$ \\
EDA6 & $-\mathrm{H}$ & $\mathrm{C}$ & 1 & $-\mathrm{CH}_{2} \mathrm{CONH}_{2}$ \\
EDA7 & $4-\mathrm{Cl}$ & $\mathrm{C}$ & 1 & $-\mathrm{CH}_{2} \mathrm{COOCH}_{3}$ \\
EDA8 & $-\mathrm{H}$ & $\mathrm{C}$ & 1 & $-\mathrm{CH}_{2} \mathrm{COOPh}$ \\
EDA9 & $4-\mathrm{Cl}$ & $\mathrm{C}$ & 1 & $-\mathrm{CH}_{2} \mathrm{COCH} \mathrm{CH}_{3}$ \\
EDA10 & $4-\mathrm{Cl}$ & $\mathrm{C}$ & 1 & $-\mathrm{CH}_{2} \mathrm{COC}\left(\mathrm{CH}_{3}\right)_{3}$ \\
EDA11 & $3,5-\mathrm{diOCH} 3$ & $\mathrm{C}$ & 1 & $-\mathrm{CH}_{2} \mathrm{COC}\left(\mathrm{CH}_{3}\right)_{3}$ \\
\hline
\end{tabular}

Appendix 4 Structures of the selenoanhydride (EDA1) and selenoesters (EDA2-

11) 


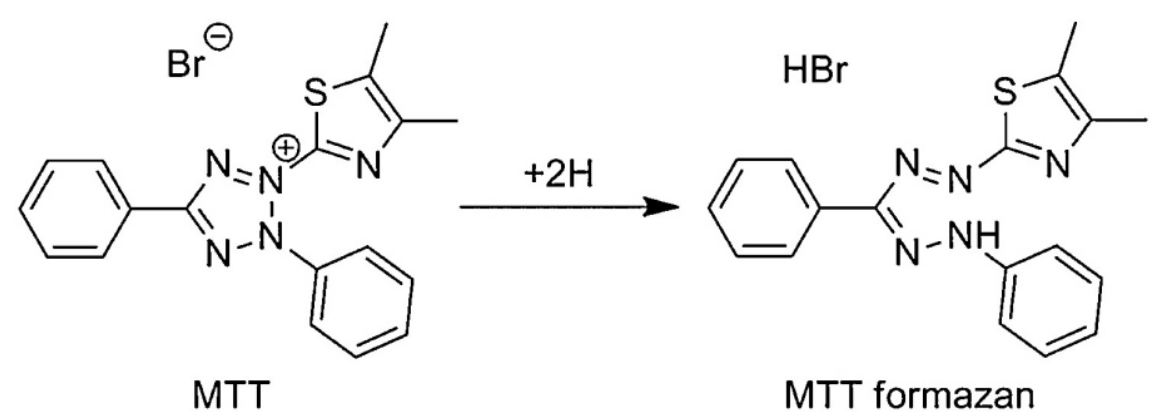

Appendix 5 MTT assay: reduction of MTT bromide to MTT formazan ${ }^{163}$

\begin{tabular}{|c|c|c|}
\hline Gene & Primer sequence (5'-3') & Amplicon size (bp) \\
\hline \multirow[t]{2}{*}{ acrA } & CTTAGCCCTAACAGGATGTG & 189 \\
\hline & TTGAAATTACGCTTCAGGAT & \\
\hline \multirow[t]{2}{*}{$\operatorname{acr} B$} & CGTACACAGAAAGTGCTCAA & 183 \\
\hline & CGCTTCAACTTTGTTTTCTT & \\
\hline \multirow[t]{2}{*}{$\operatorname{mar} R$} & AGCGATCTGTTCAATGAAAT & 170 \\
\hline & TTCAGTTCAACCGGAGTAAT & \\
\hline \multirow[t]{2}{*}{$\operatorname{sdiA}$} & CTGATGGCTCTGATGCGTTTA & 163 \\
\hline & TCTGGTGGAAATTGACCGTATT & \\
\hline \multirow[t]{2}{*}{ gapdh } & ACTTACGAGCAGATCAAAGC & 170 \\
\hline & AGTTTCACGAAGTTGTCGTT & \\
\hline \multirow[t]{2}{*}{ norA } & TCGTCTTAGCGTTCGGTTTA & 246 \\
\hline & TCCAGTAACCATCGGCAATA & \\
\hline \multirow[t]{2}{*}{ терА } & TGCTGCTGCTCTGTTCTTTA & 198 \\
\hline & GCGAAGTTTCCATAATGTGC & \\
\hline \multirow[t]{2}{*}{$16 S r R N A$} & AGAGTTTGATCMTGGCTCAG & 492 \\
\hline & GWATTACCGCGGCKGCTG & \\
\hline
\end{tabular}

Appendix 6 Forward and reverse primers used in RT-qPCR reaction 


\begin{tabular}{c|cccc}
\hline \multirow{2}{*}{ Compounds } & \multicolumn{4}{|c}{ MIC $(\boldsymbol{\mu g} / \mathbf{m L})$} \\
\cline { 2 - 5 } PY1 & $\begin{array}{c}\text { E. coli } \\
\text { AG100 }\end{array}$ & $\begin{array}{c}\text { E. coli } \\
\text { AG100 A }\end{array}$ & C. violaceum & E26 cloacae \\
PY2 & $>100$ & $>100$ & $>100$ & $\mathbf{3 1 2 9 8}$ \\
PY3 & $>100$ & $>100$ & $>100$ & $>100$ \\
PY4 & $>100$ & $>100$ & $>100$ & $>100$ \\
PY5 & $>100$ & $>100$ & $>100$ & $>100$ \\
PY6 & $>100$ & $\mathbf{5 0}$ & $>100$ & $>100$ \\
PY7 & $>100$ & $>100$ & $>100$ & $>100$ \\
PY8 & $>100$ & $>100$ & $>100$ & $>100$ \\
PY9 & $>100$ & $>100$ & $>100$ & $>100$ \\
PY10 & $>100$ & $>100$ & $>100$ & $>100$ \\
\hline
\end{tabular}

Appendix 7 Minimum inhibitory concentrations (MICs) of fluorinated P-ylides (PY1-10) on the Gram-negative strains 


\begin{tabular}{l|ccccccc}
\hline \multirow{2}{*}{ Compounds } & \multicolumn{7}{|c}{ MIC $(\boldsymbol{\mu M})$} \\
\cline { 2 - 7 } EDA & $\mathbf{2 5 9 2 3}$ & $\mathbf{2 9 2 1 2}$ & AG100 & AG100 A & $\mathbf{1 4 0 2 8 s}$ & SL1344 & L644 \\
EDA2 & 100 & $>100$ & $>100$ & $>100$ & $>100$ & $>100$ & $>100$ \\
EDA3 & 100 & $>100$ & $>100$ & $>100$ & $>100$ & $>100$ & $>100$ \\
EDA4 & 100 & $>100$ & $>100$ & $>100$ & $>100$ & $>100$ & $>100$ \\
EDA5 & $>100$ & $>100$ & $>100$ & $>100$ & $>100$ & $>100$ & $>100$ \\
EDA6 & $>100$ & $>100$ & $>100$ & $>100$ & $>100$ & $>100$ & $>100$ \\
EDA7 & 100 & $>100$ & $>100$ & $>100$ & $>100$ & $>100$ & $>100$ \\
EDA8 & 100 & $>100$ & $>100$ & $>100$ & $>100$ & $>100$ & $>100$ \\
EDA9 & $\mathbf{3 . 1 2}$ & $\mathbf{1 2 . 5}$ & $>100$ & $>100$ & $>100$ & $>100$ & $>100$ \\
EDA10 & $\mathbf{2 5}$ & $>100$ & $>100$ & $>100$ & $>100$ & $>100$ & $>100$ \\
EDA11 & $\mathbf{5 0}$ & $>100$ & $>100$ & $>100$ & $>100$ & $>100$ & $>100$ \\
\hline
\end{tabular}

25923: S. aureus ATCC 25923; 29212: E. faecalis ATCC 29212; AG100: E. coli AG100; AG100 A: E. coli AG100 A; 14028s: S. Typhimurium 14028s; SL1344: S. Typhimurium SL1344; L644: S. Typhimurium L644 $(\Delta \mathrm{acrB})$

Appendix 8 Minimum inhibitory concentrations (MICs) of selenocompounds (EDA1-11) on Gram-positive and Gram-negative strains 


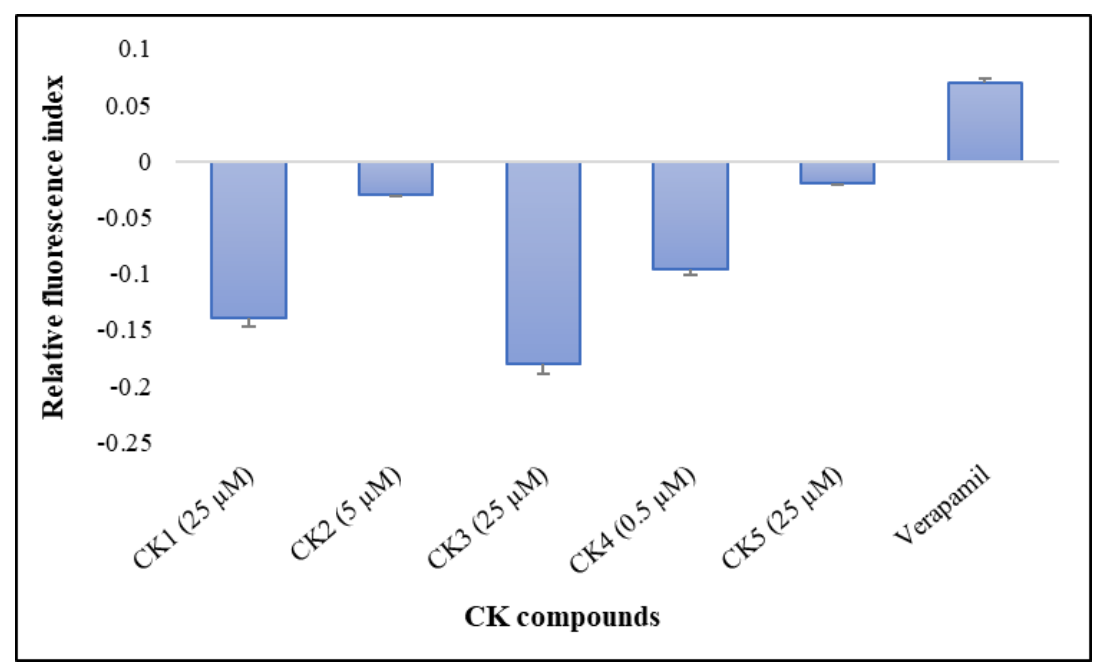

Appendix 9 Relative final fluorescence index (RFI) of CK compounds (CK1-5) on methicillin and ofloxacin resistant $S$. aureus 272123 at different concentrations

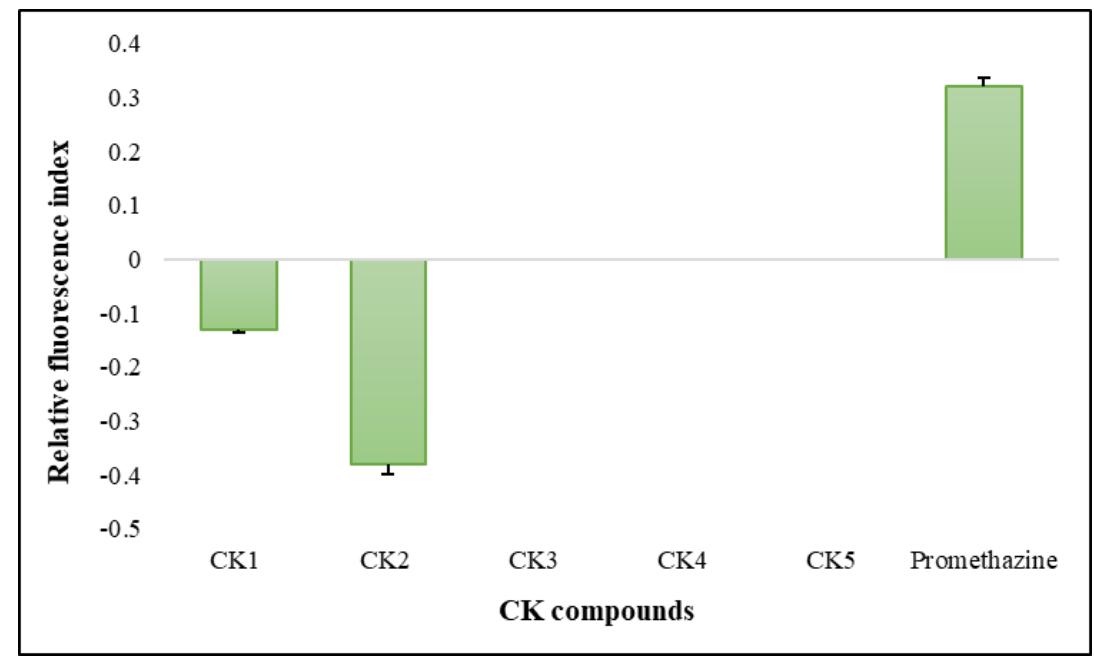

Appendix 10 Relative final fluorescence index (RFI) CK compounds (CK1-5) on E. coli AG100 A at $50 \mu \mathrm{M}$ 


\section{TÁRSSZERZÖI LEMONDÓ NYILATKOZAT}

Alulírott Dr. Mosolygó Tímea kijelentem, hogy Kincses Annamária PhD értekezésének tézispontjaiban bemutatott - közösen publikált - tudományos eredmények elérésében a pályázónak meghatározó szerepe volt, ezért ezeket a téziseket más a $\mathrm{PhD}$ fokozat megszerzését célzó minősítési eljárásban nem használta fel, illetve nem kívánja felhasználni.

dátum

Dr. Mosolygó Tímea

szerző

Dr. Spengler Gabriella

témavezető

A pályázó tézispontjaiban érintett, közösen publikált közlemény:

Mosolygó T, Kincses A, Csonka A, Tönki ÁS, Witek K, Sanmartín C, Marć MA, Handzlik J,

Kieć-Kononowicz K, Domínguez-Álvarez E, Spengler G. Selenocompounds as novel antibacterial agents and bacterial efflux pump inhibitors. Molecules. 24: E1487, 2019. 


\section{PUBLICATIONS}

I. 


\title{
Fluorinated Beta-diketo Phosphorus Ylides Are Novel Efflux Pump Inhibitors in Bacteria
}

\author{
ANNAMÁRIA KINCSES ${ }^{1}$, ÁGNES MÍRA SZABÓ ${ }^{1}$, RYOSUKE SAIJO $^{2}$, GENKI WATANABE ${ }^{2}$, \\ MASAMI KAWASE ${ }^{2}$, JOSEPH MOLNÁR ${ }^{1}$ and GABRIELLA SPENGLER ${ }^{1}$ \\ ${ }^{1}$ Department of Medical Microbiology and Immunobiology, Faculty of Medicine, \\ University of Szeged, Szeged, Hungary; \\ ${ }^{2}$ Faculty of Pharmaceutical Sciences, Matsuyama University, Matsuyamas, Japan
}

\begin{abstract}
Background: One of the most important resistance mechanisms in bacteria is the increased expression of multidrug efflux pumps. To combat effluxrelated resistance, the development of new efflux pump inhibitors is essential. Materials and Methods: Ten phosphorus ylides were compared based on their MDRreverting activity in multidrug efflux pump system consisting of the subunits acridine-resistance proteins $A$ and $B$ (AcrA and $A(r B)$ and the multidrug efflux pump outer membrane factor TolC (TolC) of Escherichia coli K-12 AG100 strain and its AcrAB-TolC-deleted strain. Efflux inhibition was assessed by real-time fluorimetry and the inhibition of quorum sensing (QS) was also investigated. The relative gene expression of efflux QS genes was determined by realtime reverse transcriptase quantitative polymerase chain reaction. Results: The most potent derivative was $\mathrm{Ph}_{3} \mathrm{P}=\mathrm{C}\left(\mathrm{COC}_{2} \mathrm{~F}_{5}\right) \mathrm{CHO}$ and its effect was more pronounced on the AcrAB-TolC-expressing E. coli strain, furthermore the most active compounds, $\mathrm{Ph}_{3} \mathrm{P}=\mathrm{C}\left(\mathrm{COCF}_{3}\right) \mathrm{OMe}$, $\mathrm{Ph}_{3} \mathrm{P}=\mathrm{C}\left(\mathrm{COC}_{2} \mathrm{~F}_{5}\right) \mathrm{CHO}$ and $\mathrm{Ph}_{3} \mathrm{P}=\mathrm{C}\left(\mathrm{COCF}_{3}\right) \mathrm{COMe}$, reduced the expression of efflux pump and $Q S$ genes. Conclusion: Phosphorus ylides might be valuable EPI compounds to reverse efflux related MDR in bacteria.
\end{abstract}

Multidrug resistance (MDR) is a serious problem for the treatment of various diseases, such as bacterial and fungal infections and cancer, due to reduction or deficit response of

Correspondence to: Gabriella Spengler, Department of Medical Microbiology and Immunobiology, Faculty of Medicine, University of Szeged, Dóm tér 10, H-6720 Szeged, Hungary. Tel: +36 62545115, Fax: +36 62545113, e-mail: spengler.gabriella@med.uszeged.hu

Key Words: Phosphorus ylides, multidrug resistance, bacterial AcrAB-TolC, efflux pump, quorum sensing. microorganisms as well as cancer cells to applied chemotherapeutic agents $(1,2)$.

One of the major mechanisms of MDR is the overexpression of efflux pumps (EPs), which reduces the accumulation of toxic agents. In bacteria the resistance nodulation division (RND) transporters have a great impact on MDR phenotype. The major cause for the MDR phenotype is due to overexpression of efflux pumps that are part of the RND family of transporters, for example the acridineresistance proteins $\mathrm{A}$ and $\mathrm{B}$ (AcrA and AcrB) and the multidrug efflux pump outer membrane factor TolC (TolC) AcrAB-TolC system (1). These efflux pumps have the ability to recognize and extrude a large variety of unrelated antibiotics from the periplasmic space of the cell envelope, or from the cytoplasm. The energy required for the operation of the efflux pump is provided by the proton motive force created by the proton gradient resulting from electron transport (3).

The quorum-sensing system (QS) in bacteria is a regulatory system that controls gene expression depending on the density of the bacterial cell population. A transcriptional regulator (LuxR homolog), signal synthase (LuxI homolog) and autoinducer (acyl homoserine lactone) are crucial for the QS in most Gram-negative bacteria. SdiA, an E. coli LuxR homolog, has a great impact on the colonization of $E$. coli $(4,5)$. SdiA is a homolog of QS regulators that detects $N$-acylhomoserine lactone (AHL) signals from other bacteria. SdiA represses the expression of virulence factors by interacting with unknown stationaryphase signals in E. coli $\mathrm{O} 157: \mathrm{H7}$, and enhances multidrug resistance by activating MDR efflux pumps in E. coli (6).

Organic compounds of phosphorus ylides (P-ylides) are a fascinating class of compounds (7). The biological activity of P-ylides related to their ATP-binding cassette subfamily $B$ member 1 (ABCB1)-modulating activity in mouse lymphoma cells has already been described (8), however, additional information is needed to describe their valuable biological activities in other aspects. 
In this article, we report the MDR-modulating activities of P-ylides in bacteria related to the inhibition of efflux activity and QS.

\section{Materials and Methods}

Compounds. The synthesis of P-ylides was described previously (8) and the structures of the P-ylides (compounds 1-10) screened for their MDR-modulating activities are shown in Table I. The compounds were dissolved in dimethyl sulfoxide (DMSO) for the experiments.

Acridine orange (AO), ethidium bromide (EB), and LB broth were purchased from Sigma-Aldrich Chemie GmbH (Steinheim, Germany). Modified LB agar (LB*) contained 5 g yeast extract, 10 g trypton, $10 \mathrm{~g} \mathrm{NaCl}, 1 \mathrm{~g} \mathrm{~K}_{2} \mathrm{HPO}_{4}, 0.3 \mathrm{~g} \mathrm{MgSO}_{4} .7 \mathrm{H}_{2} \mathrm{O}$ and 36 mg FeNaEDTA in 1.01 of distilled water. Mueller Hinton broth was purchased from Scharlau Chemie S.A. (Barcelona, Spain).

Bacterial strains. Wild-type E. coli K-12 AG100 strain [argE3 thi-1 rpsL xyl mtl $\Delta$ (gal-uvrB) supE44] expressing the AcrABTolC EP at its basal level and its AcrAB-TolC-deleted mutant strain (E. coli $\mathrm{K}-12$ AG100A). The strains were kindly provided by Professor Dr. Hiroshi Nikaido (Department of Molecular and Cell Biology and Chemistry, University of California, Berkeley, CA, USA).

Strains used for QS tests: Chromobacterium violaceum 026 (CV026) as sensor strain; Sphingomonas spp. EZF 10-17 (Sphingomonadaceae) isolated from a grapevine crown gall tumor (used as AHL producer), this strain induced pigment production by CV026 and proved to be efficient for the study of QS interactions; Enterobacter cloaceae 31298 (clinical wound isolate, used as AHL producer).

Determination of minimum inhibitory concentrations. The minimum inhibitory concentrations (MICs) of P-ylides were tested according to Clinical and Laboratory Standard Institute guidelines (9).

Real-time accumulation assay by Roche LightCycler real-time thermocycler. The effect of the studied compounds on the realtime accumulation of EB was assessed by an automated EB method (10), using a LightCycler real-time thermocycler (LightCycler 1.5; Roche, Indianapolis, IN, USA). Briefly, an aliquot of an overnight culture of the strain in LB medium was transferred to fresh LB medium and incubated until it reached an optical density (OD) of 0.6 at $600 \mathrm{~nm}$. It was then washed with phosphate-buffered saline (PBS; $\mathrm{pH} 7.4$ ) and centrifuged at $13,000 \times g$ for $3 \mathrm{~min}$, the pellets re-suspended in PBS ( $\mathrm{pH} \mathrm{7.4)}$ and the OD adjusted to 0.6 at $600 \mathrm{~nm}$. The compounds were added individually at different concentrations (in double concentrated form) in $5 \mu$ volumes of their stock solutions to 45 $\mu \mathrm{l}$ of EB solution of $2 \mathrm{mg} / \mathrm{l}$ in PBS. Then, $10 \mu \mathrm{l}$ of the EB solution containing the compound were transferred into standard glass capillary tubes of $20 \mu \mathrm{l}$ maximum volume (Roche) and 10 $\mu \mathrm{l}$ of bacterial suspension (OD of 0.6 at $600 \mathrm{~nm}$ ) was added to the capillaries. The capillaries containing the samples were placed into a carousel (Roche) and the fluorescence was monitored at the FL-2 channel every minute on a real-time basis.

From the real-time data, the activity of the compound, namely the relative fluorescence index (RFI) of the last time point (minute
30) of the EB accumulation assay was calculated according to the formula:

$$
R F I=\frac{R F_{\text {treated }}-R F_{\text {untreated }}}{R F_{\text {untreated }}}
$$

where $R F_{\text {treated }}$ is the relative fluorescence at the last time point of the EB retention curve in the presence of an inhibitor, and $R F_{\text {untreated }}$ is the relative fluorescence at the last time point of the EB retention curve of the untreated solvent control (DMSO).

Assay for QS inhibition. LB* was used for these experiments. The sensor strain $C$. violaceum 026 (CV026) and the AHL producer strains EZF 10-17 Sphingomonas spp. (Sphingomonadaceae) or E. cloaceae 31298 were inoculated as parallel lines and incubated at room temperature $\left(20^{\circ} \mathrm{C}\right)$ for $24-48 \mathrm{~h}$. QS inhibition was monitored by agar diffusion method. Filter paper discs $(7.0 \mathrm{~mm}$ in diameter) were impregnated with $10 \mu \mathrm{l}$ of stock solutions of the compounds in DMSO (10 mg/ml in DMSO). The discs were placed between the parallel lines of sensor and AHL producer strains on the surface of the nutrient agar. The plates were incubated at room temperature for a further 24-48 $\mathrm{h}$ and the interactions between the strains and compounds were evaluated for the reduction in size of the zone of pigment production and the zone of growth inhibition of the affected strains, in millimeters. AO was applied as positive control (11).

Expression analyses of genes by real-time reverse transcriptase quantitative polymerase chain $(R T-q P C R)$ reaction. Bacteria were cultured in LB broth and were incubated overnight at $37^{\circ} \mathrm{C}$ with shaking. On the day of RNA isolation, the bacterial suspensions (OD of 0.6 at $600 \mathrm{~nm}$ ) were transferred to $10 \mathrm{ml}$ tubes in $3 \mathrm{ml}$ aliquots and $50 \mu \mathrm{g} / \mathrm{ml}$ of compounds were added to the tubes which were the incubated at $37^{\circ} \mathrm{C}$. At intervals of 4 and $18 \mathrm{~h}$ of culture, the tubes were centrifuged at $12,000 \times g$ for $2 \mathrm{~min}$. Pellets were suspended in $100 \mu \mathrm{l}$ TE buffer containing $1 \mathrm{mg} / \mathrm{ml}$ lysozyme by vigorous vortexing and were incubated at $37^{\circ} \mathrm{C}$ for $10 \mathrm{~min}$. The total RNA was isolated in an RNase-free environment using NucleoSpin RNA kit (Macherey Nagel, Germany) according to the manufacturer's instructions. Purified RNA was stored in RNasefree water in nuclease-free collection tubes and was maintained at $-20^{\circ} \mathrm{C}$ until quantification was performed. The concentration of the extracted RNA templates was assessed by spectrophotometry at $260 \mathrm{~nm}$.

Expression of the $a c r A, a c r B$, multiple antibiotic resistance protein $\mathrm{R}$ (marR) and quorum-sensing transcriptional activator (sdiA) genes was studied by reverse transcription of total RNA. The data obtained for gene targets were normalized against the $E$. coli house-keeping gene glyceraldehyde-3-phosphate-dehydrogenase (gapdh) measured in the same sample. Real-time quantification of the RNA templates by real-time one-step RT-qPCR was performed in a CFX96 Touch realtime PCR detection system (Bio-Rad, Hercules, CA, USA) strictly adhering to the manufacturer recommendations of the SensiFAST ${ }^{\mathrm{TM}}$ SYBR No-ROX One-Step Kit (Bioline GmbH, Luckenwalde, Germany). Briefly, each well of 96-well microtiter plates contained, in a final volume of $20 \mu \mathrm{l}, 10 \mu \mathrm{l}$ of the 2 SensiFAST $^{\mathrm{TM}}$ SYBR NoROX One-Step Mix, $0.2 \mu$ l Reverse Transcriptase, $0.4 \mu$ l RiboSafe RNase Inhibitor, $5.4 \mu$ diethylpyrocarbonate-treated water, $500 \mathrm{nM}$ of each primer and approximately $20 \mathrm{ng}$ of total RNA in RNAase-free water. Thermal cycling was initiated with a denaturation step of $5 \mathrm{~min}$ 
Table I. Structures of P-ylides (compounds 1-10).

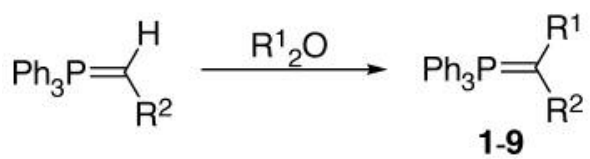

\begin{tabular}{lcc}
\hline Compound & \multicolumn{1}{c}{$\mathrm{R}^{1}$} & $\mathrm{R}^{2}$ \\
\hline $\mathbf{1}$ & $\mathrm{COCF}_{3}$ & $\mathrm{CN}$ \\
$\mathbf{2}$ & $\mathrm{COCF}_{3}$ & $\mathrm{OMe}$ \\
$\mathbf{3}$ & $\mathrm{COCF}_{3}$ & $\mathrm{COPh}$ \\
$\mathbf{4}$ & $\mathrm{COCF}_{3}$ & $\mathrm{CHO}$ \\
$\mathbf{5}$ & $\mathrm{COCF}_{3}$ & $\mathrm{COMe}$ \\
$\mathbf{6}$ & $\mathrm{COCF}_{3}$ & $\mathrm{CO} 2 \mathrm{Et}$ \\
$\mathbf{7}$ & $\mathrm{COC}_{2} \mathrm{~F}_{5}$ & $\mathrm{COPh}$ \\
$\mathbf{8}$ & $\mathrm{COC}_{3} \mathrm{~F}_{7}$ & $\mathrm{COPh}$ \\
$\mathbf{9}$ & $\mathrm{COCH}_{3}$ & $\mathrm{CN}$ \\
$\mathbf{1 0}$ & $\mathrm{H}$ & $\mathrm{CN}$ \\
\hline
\end{tabular}

at $95^{\circ} \mathrm{C}$, followed by 40 cycles each of $10 \mathrm{~s}$ at $95^{\circ} \mathrm{C}, 30 \mathrm{~s}$ at $57^{\circ} \mathrm{C}$ and $20 \mathrm{~s}$ at $72^{\circ} \mathrm{C}$.

The forward and reverse primers used for assessment of the activity of the transporter genes $\operatorname{acr} A, \operatorname{acr} B$, the regulator $\operatorname{mar} R$ and the QS regulator $s d i A$ are shown in Table II.

\section{Results}

Compounds 1-10 did not have any antibacterial effect on the AcrAB-TolC-expressing E. coli AG100 (MDR) strain nor its AcrAB-TolC-deleted progeny E. coli AG100A (EP-deleted strain) (MIC above $100 \mu \mathrm{g} / \mathrm{ml}$ ), except for $\mathbf{6}$, which had a mild, non-significant effect on the EP-deleted strain $(\mathrm{MIC}=50 \mu \mathrm{g} / \mathrm{ml})$.

The activity of the compounds was compared based on the relative final fluorescence index (RFI) of the real-time accumulation curves (Table III).

In the case of real-time EB accumulation by Light Cycler thermocycler, the amount of EB accumulated by cells is higher if the difference between $\mathrm{RF}_{\text {treated }}$ and $\mathrm{RF}_{\text {untreated }}$ is greater, therefore, the degree of inhibition of the EP system by the compound becomes greater.

The majority of the P-ylides were found to inhibit the AcrAB-TolC system of $E$. coli except $\mathrm{Ph}_{3} \mathrm{P}=\mathrm{C}\left(\mathrm{COCF}_{3}\right) \mathrm{COPh}$ (3), $\mathrm{Ph}_{3} \mathrm{P}=\mathrm{C}\left(\mathrm{COC}_{2} \mathrm{~F}_{5}\right) \mathrm{COPh}(7)$ and $\mathrm{Ph}_{3} \mathrm{P}=\mathrm{C}\left(\mathrm{COC}_{3} \mathrm{~F}_{7}\right) \mathrm{COPh}$ (8), which had little or no effect on the intracellular $\mathrm{EB}$ accumulation in the E. coli AG100 and the AG100A strains. Among the P-ylide series, $\mathrm{Ph}_{3} \mathrm{P}=\mathrm{C}\left(\mathrm{COCF}_{3}\right) \mathrm{OMe}$ (2), $\mathrm{Ph}_{3} \mathrm{P}=\mathrm{C}\left(\mathrm{COCF}_{3}\right) \mathrm{CHO}(4)$ and $\mathrm{Ph}_{3} \mathrm{P}=\mathrm{C}\left(\mathrm{COCF}_{3}\right) \mathrm{COMe}(\mathbf{5})$ exhibited strong AcrAB-TolC pump-inhibiting properties compared to the AcrAB-TolC pump-deficient mutant strain. The most potent derivative was $\mathbf{4}$ and its effect was more
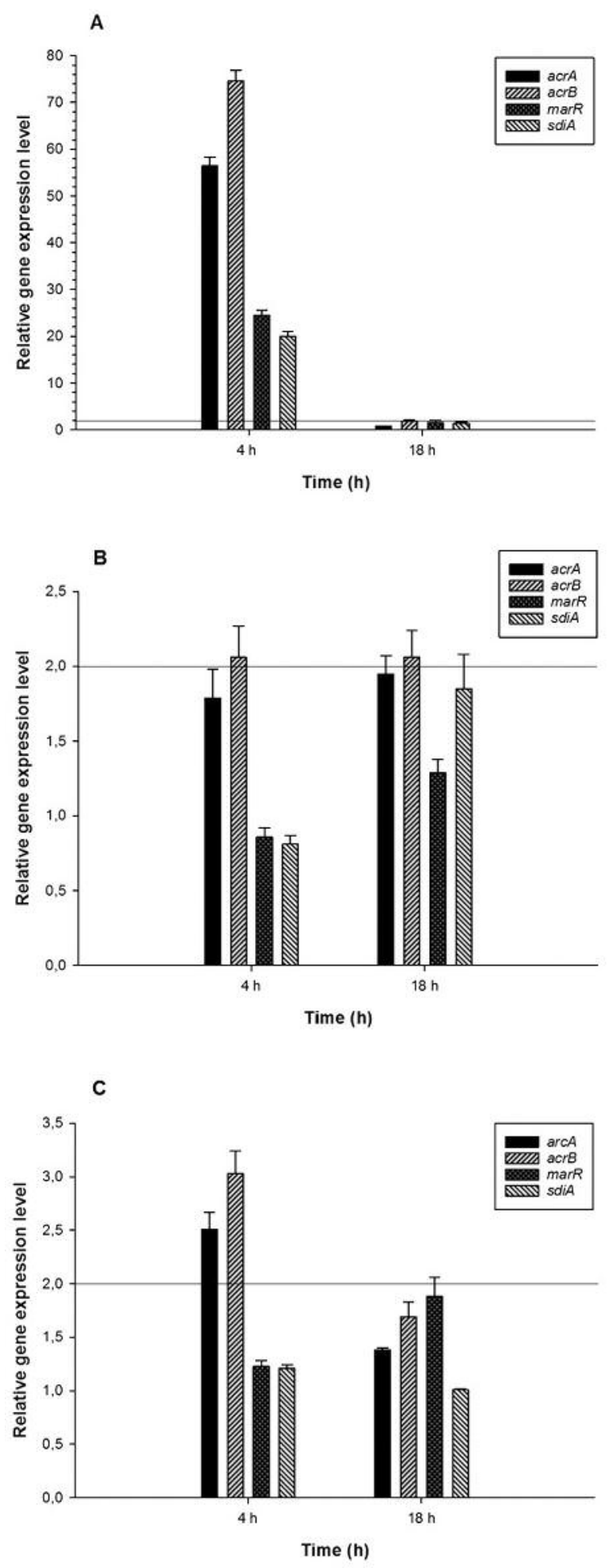

Figure 1. Relative gene expression levels of the genes of the acridine resistance protein $A(a c r A)$, acridine resistance protein $B(a c r B)$, multiple antibiotic resistance protein $R$ (marR) and quorum-sensing transcriptional activator (sdiA) in the presence of compounds 2 (A), 4 $(B)$, and $5(C)$ after 4 and 18 h exposure in $L B$. The line denotes the threshold value, which was set at a two-fold increase in transcripts. 
Table II. Forward and reverse primers used for assessment of the activity of the transporter genes acrA and acrB, the regulator marR and the quorum-sensing regulator sdiA of Escherichia coli AG100.

\begin{tabular}{|c|c|c|c|c|}
\hline Gene & Full name & Primer sequence $\left(5^{\prime}-3^{\prime}\right)$ & $\begin{array}{c}\text { Amplicon } \\
\text { size (bp) }\end{array}$ & Reference \\
\hline acrA & Acridine-resistance protein A & CTTAGCCCTAACAGGATGTGTTGAAATTACGCTTCAGGAT & 189 & $(12)$ \\
\hline$a c r B$ & Acridine-resistance protein B & CGTACACAGAAAGTGCTCAACGCTTCAACTTTGTTTTCTT & 183 & $(12)$ \\
\hline $\operatorname{marR}$ & Multiple antibiotic-resistance protein $\mathrm{R}$ & AGCGATCTGTTCAATGAAATTTCAGTTCAACCGGAGTAAT & 170 & (12) \\
\hline sdiA & Quorum-sensing transcriptional activator & CTGATGGCTCTGATGCGTTTATCTGGTGGAAATTGACCGTATT & 163 & This study \\
\hline gapdh & Glyceraldehyde-3-phospate dehydrogenase & ACTTACGAGCAGATCAAAGCAGTTTCACGAAGTTGTCGTT & 170 & $(12)$ \\
\hline
\end{tabular}

pronounced on the MDR E. coli strain compared to the pump-deleted $E$. coli strain. This activity suggests that the compound may interfere with the proton motive force because AcrB utilizes proton motive force as energy for its transport function.

The P-ylides were not able to inhibit the QS in the applied systems compared to the positive control AO (data not shown).

Regarding the effect of P-ylides on the relative expression of efflux pump and QS genes in E. coli AG100, the most effective compounds $\mathbf{2}, \mathbf{4}$, and $\mathbf{5}$ were selected for geneexpression studies. In the assay, the gene of the multidrug efflux pump subunit AcrB, the gene of the periplasmic AcrA subunit, the component of the E. coli mar locus (multiple antibiotic resistance), and the gene of the LuxR homolog SdiA were investigated. As shown in Figure 1A, compound 2 at $50 \mu \mathrm{g} / \mathrm{ml}$ up-regulated all the genes studied after $4 \mathrm{~h}$ of exposure, however, after $18 \mathrm{~h}$, the gene expression returned to basal levels. Compound $\mathbf{4}$ also significantly up-regulated the secondary RND transporter gene $a c r B$ (approximately 2fold increase) after $4 \mathrm{~h}$ and $18 \mathrm{~h}$ exposures as well. Surprisingly, there was up-regulation of $s d i A$ expression after $18 \mathrm{~h}$ compared to the expression level after $4 \mathrm{~h}$ implicating the ability of compound 2 to influence the QS gene sdiA, however, this increase was not significant (Figure 1B). Compound 5 up-regulated the expression levels of $\operatorname{acr} A$ and $a c r B$ after $4 \mathrm{~h}$, although after $18 \mathrm{~h}$, the up-regulation of these genes was not significant (less than 2-fold increase) as presented by Figure 1C.

\section{Discussion}

Some phenothiazines and hydantoins are known to be EPIs against both bacteria and cancer cells (13). However, Pylides 3, 7 and $\mathbf{8}$ have been shown to have activity against the EPs of cancer cells (8), but not to have activity against the EP of bacteria. It is important to note that $\mathrm{ABC}$ transporters are primary efflux pumps deriving their energy from the hydrolysis of ATP, however, the AcrAB-TolC system is a three-component proton motive force-dependent multidrug efflux system. The most effective compounds in
Table III. Relative final fluorescence index (RFI) for the effect of P-ylides (compounds 1-10) on Escherichia coli AG100 expresing acridine-resistance proteins $A$ and $B$ and the multidrug efflux pump outer membrane factor TolC, and the pump-deleted E. coli AG100A strain at $50 \mu \mathrm{g} / \mathrm{ml}$.

\begin{tabular}{lcc}
\hline Compound & \multicolumn{2}{c}{ RFI $^{\mathrm{a}}$} \\
\cline { 2 - 3 } & AG100 & AG100A \\
\hline $\mathbf{1}$ & 0.36 & 0.46 \\
$\mathbf{2}$ & 0.64 & 0.49 \\
$\mathbf{3}$ & 0.04 & 0.12 \\
$\mathbf{4}$ & 0.73 & 0.46 \\
$\mathbf{5}$ & 0.42 & 0.27 \\
$\mathbf{6}$ & 0.25 & 0.49 \\
$\mathbf{7}$ & 0.02 & 0 \\
$\mathbf{8}$ & 0 & 0.19 \\
$\mathbf{9}$ & 0.29 & 0.32 \\
$\mathbf{1 0}$ & 0.42 & 0.44 \\
\hline
\end{tabular}

aRFI was calculated according to the formula:

$$
R F I=\frac{R F_{\text {treated }}-R F_{\text {untreated }}}{R F_{\text {untreated }}}
$$

where $R F_{\text {treated }}$ is the relative fluorescence at the last point (30 min) of the ethidium bromide (EB) retention curve in the presence an P-ylide and $R F_{\text {untreated }}$ is the relative fluorescence at the last point $(30 \mathrm{~min})$ of the EB retention curve of the untreated solvent control dimethyl sulfoxide.

the present bacterial system were compounds $\mathbf{2}, \mathbf{4}$, and $\mathbf{5}$, which inhibited the AcrAB-TolC system and influenced the expression of the genes $\operatorname{acr} A$ and $\operatorname{acr} B$, which are constituents of the AcrAB-TolC system. In addition, although the compounds are not QS inhibitors, compound 4 did increase the expression of $s d i A$ after $18 \mathrm{~h}$ exposure.

It can be concluded that in the $\mathrm{COCF}_{3}$ series (compounds 1-6), the MDR-reverting activity in the MDR E. coli strain was intensified in the following order: $\mathrm{CHO}(4)>\mathrm{OMe}(2)$, COMe (5) $>\mathrm{CO}_{2} \mathrm{Et}(\mathbf{6}), \mathrm{COPh}(\mathbf{3}), \mathrm{CN}$ (1). 
Thus, some structurally related trifluoroacetylated P-ylides differ in their MDR-reversal activities between cancer cells and bacterial strains, indicating that the compounds differently act as inhibitors of primary (ABCB1) and secondary (AcrB) efflux pumps because these pumps differ in their energy source for driving the pump (ATP and PMF, respectively).

The present study demonstrated that trifluoroacetylated Pylides may be attractive lead EPIs for further development as a MDR-reversing agents, however, their mode of action should be elucidated by structure-activity relationship studies.

\section{Acknowledgements}

This research was supported by the Szeged Foundation for Cancer Research, the European Union and the State of Hungary, cofinanced by the European Social Fund in the framework of TÁMOP 4.2.4. A/2-11-1-2012-0001 'National Excellence Program'. This article was supported by the János Bolyai Research Scholarship of the Hungarian Academy of Sciences.

\section{References}

1 Tanwar J, Das S, Fatima Z and Hameed S: Multidrug resistance: an emerging crisis. Interdiscip Perspect Infect Dis 541340. doi: 10.1155/2014/541340, 2014.

2 Nikaido H: Multidrug resistance in bacteria. Annu Rev Biochem 78: 119-146, 2009.

3 Nikaido H and Pagès JM: Broad-specificity efflux pumps and their role in multidrug resistance of Gram-negative bacteria. FEMS Microbiol Rev 36: 340-363, 2012.

4 Kanamaru K, Kanamaru K, Tatsuno I, Tobe T and Sasakawa C: SdiA, an Escherichia coli homologue of quorum-sensing regulators, controls the expression of virulence factors in enterohaemorrhagic Escherichia coli O157:H7. Mol Microbiol 38: 805-816, 2000.

5 Tavío MM, Aquili VD, Poveda JB, Antunes NT, SánchezCéspedes J and Vila J: Quorum-sensing regulator sdiA and marA overexpression is involved in in vitro-selected multidrug resistance of Escherichia coli. J Antimicrob Chemother 65: 1178-1186, 2010
6 Lee J, Maeda T, Hong SH and Wood TK: Reconfiguring the quorum-sensing regulator SdiA of Escherichia coli to control biofilm formation via indole and $\mathrm{N}$-acylhomoserine lactones. Appl Environ Microbiol 75: 1703-1716, 2009.

7 El-Batta A, Jiang C, Zhao W, Anness R, Cooksy AL and Bergdahl M: Wittig reactions in water media employing stabilized ylides with aldehydes. Synthesis of alpha,betaunsaturated esters from mixing aldehydes, alpha-bromoesters, and $\mathrm{Ph} 3 \mathrm{P}$ in aqueous NaHCO3. J Org Chem 72: 5244-5259, 2007.

8 Spengler G, Ocsovszki I, Tönki Ás, Saijo R, Watanabe G, Kawase $\mathrm{M}$ and Molnár J: Fluorinated $\beta$-diketo phosphorus ylides are novel inhibitors of the ABCB1 efflux pump of cancer cells. Anticancer Res 35: 5915-5919, 2015.

9 Clinical and Laboratory Standard Institute guidelines. http://clsi.org/

10 Viveiros M, Martins A, Paixão L, Rodrigues L, Martins M, Couto I, Fähnrich E, Kern WV and Amaral L: Demonstration of intrinsic efflux activity of Escherichia coli K-12 AG100 by an automated ethidium bromide method. Int J Antimicrob Agents 31: 458-462, 2008

11 Varga GZ, Szabo MA, Schelz Zs, Szegedi E, Amaral L and Molnár J: Quorum sensing inhibition by phenothiazines and related compounds. Lett Drug Design Discovery 8: 133-137, 2011.

12 Viveiros M, Dupont M, Rodrigues L, Couto I, Davin-Regli A, Martins M, Pagès JM and Amaral L: Antibiotic stress, genetic response and altered permeability of E. coli. PLoS One 2: e365, 2007.

13 Amaral L, Spengler G, Martins A, Armada A, Handzlik J, KiecKononowicz $\mathrm{K}$ and Molnar $\mathrm{J}$ : Inhibitors of bacterial efflux pumps that also inhibit efflux pumps of cancer cells. Anticancer Res 32: 2947-2957, 2012
Received July 22, 2016

Revised August 29, 2016

Accepted September 5, 2016 
II. 


\title{
Bioactive compounds from the African medicinal plant Cleistochlamys kirkii as resistance modifiers in bacteria
}

\author{
Annamária Kincses ${ }^{1}$ | Borisz Varga ${ }^{1}$ | Ákos Csonka ${ }^{1,2}$ | Shirley Sancha ${ }^{3}$ | Silva Mulhovo ${ }^{4}$ | \\ Ana Margarida Madureira ${ }^{3}$ | Maria-José U. Ferreira ${ }^{3}$ (D) | Gabriella Spengler ${ }^{1}$
}

\author{
${ }^{1}$ Department of Medical Microbiology and \\ Immunobiology, Faculty of Medicine, \\ University of Szeged, Dóm tér 10, Szeged \\ 6720, Hungary \\ ${ }^{2}$ Department of Traumatology, Faculty of \\ Medicine, University of Szeged, Semmelweis \\ utca 6, Szeged 6725, Hungary \\ ${ }^{3}$ Research Institute for Medicines (iMed. \\ Ulisboa), Faculty of Pharmacy, University of \\ Lisbon, Avenue Professor Gama Pinto, Lisbon \\ 1649-003, Portugal \\ ${ }^{4}$ Mozambican and Ethnoscience Study Center \\ (CEMEC), Faculty of Mathematics and Natural \\ Sciences, Pedagogic University, Lhanguene \\ Campus, Av. de Moçambique, Maputo \\ 21402161, Mozambique \\ Correspondence \\ Gabriella Spengler, Department of Medical \\ Microbiology and Immunobiology, Faculty of \\ Medicine, University of Szeged, Dóm tér 10, \\ Szeged 6720, Hungary. \\ Email: spengler.gabriella@med.u-szeged.hu \\ Funding information \\ Portuguese Foundation for Science and Tech- \\ nology (FCT), Grant/Award Numbers: UID/ \\ DTP/04138/2013 and PTDC/QEQ-MED/ \\ 0905/2012; European Social Fund, Grant/ \\ Award Number: TÁMOP 4.2.4. A/2-11-1- \\ 2012-0001; ÚNKP-17-3 New National Excel- \\ lence Program of the Ministry of Human \\ Capacities of Hungary; János Bolyai Research \\ Scholarship of the Hungarian Academy of Sci- \\ ences; University of Szeged, Hungary, Grant/ \\ Award Number: GINOP-2.3.2-15-2016- \\ 00012; European Union and the State of \\ Hungary
}

Cleistochlamys kirkii (Benth) Oliv. (Annonaceae) is a medicinal plant traditionally used in Mozambique to treat infectious diseases. The aim of this study was to find resistance modifiers in C. kirkii for Gram-positive and Gram-negative model bacterial strains. One of the most important resistance mechanisms in bacteria is the efflux pump-related multidrug resistance. Therefore, polycarpol (1), three C-benzylated flavanones (2-4), and acetylmelodorinol (5) were evaluated for their multidrug resistance-reverting activity on methicillin-susceptible and methicillin-resistant Staphylococcus aureus and Escherichia coli AG100 and AG100 A strains overexpressing and lacking the AcrAB-TolC efflux pump system. The combined effects of antibiotics and compounds ( 2 and 4) were also assessed by using the checkerboard microdilution method in both $S$. aureus strains. The relative gene expression of the efflux pump genes was determined by real-time reverse transcriptase quantitative polymerase chain reaction. The inhibition of quorum sensing was also investigated. The combined effect of the antibiotics and compound 2 or 4 on the methicillinsensitive S. aureus resulted in synergism. The most active compounds 2 and $\mathbf{4}$ increased the expression of the efflux pump genes. These results suggested that $C$. kirkii constituents could be effective adjuvants in the antibiotic treatment of infections.

\section{KEYWORDS}

C-benzylated flavanones, Cleistochlamys kirkii, efflux pump, Escherichia coli AG100, methicillinresistant Staphylococcus aureus, quorum sensing

\section{1 | INTRODUCTION}

The increasing resistance of bacterial isolates is a high concern in the therapy of infectious diseases. The widespread and inappropriate use of antibiotics has contributed to the selection of resistant bacteria. Multidrug-resistant (MDR) bacteria show resistance against a broad range of antimicrobials, and one of the most important resistance mechanisms is the presence of multidrug-resistant efflux pumps (EPs). These membrane proteins have physiological functions, and they are involved in the extrusion of toxic substances into the environment (Aparna, Dineshkumar, Mohanalakshmi, Velmurugan, \& Hopper, 2014; Webber \& Piddock, 2003).

In Staphylococcus aureus, the most studied MDR pump is the chromosomally encoded NorA, which is a member of the major facilitator superfamily. NorA can transport hydrophilic compounds, quaternary ammonium compounds, and dyes. The MepA chromosomally encoded efflux transporter described in S. aureus belongs to the multidrug and toxic compound extrusion family. MepA can recognize fluoroquinolones, 
glycylcyclines, dyes, and quaternary ammonium compounds (Costa, Viveiros, Amaral, \& Couto, 2013).

The discovery of plant-derived antimicrobials has drawn particular attention (Balogh et al., 2014; Hintz, Matthews, \& Di, 2015). Numerous phytochemicals have minimal toxic activity, and they could be used in order to overcome drug resistance in bacteria by blocking multidrug EPs (Stavri, Piddock, \& Gibbons, 2007). It is important to note that EP inhibitors (EPIs) from plant sources can inhibit the activity of bacterial efflux systems; furthermore, they can potentiate the efficacy of antibiotics as well. It has been described that reserpine, isolated from the roots of Rauwolfia vomitoria, inhibits the Bmr EP of Bacillus subtilis (Klyachko, Schuldiner, \& Neyfakh, 1997). Several Berberis species producing berberine were also found to synthesize $5^{\prime}$-methoxyhydnocarpin, an inhibitor of the NorA MDR pump of S. aureus (Stermitz, Lorenz, Tawara, Zenewicz, \& Lewis, 2000). Cucurbitane-type triterpenoids, isolated from the aerial parts of the African medicinal plant Momordica balsamina, have shown activity against the EP systems of Gram-positive bacteria (Ramalhete, Da Cruz, et al., 2011a; Ramalhete, Lopes, et al., 2011b; Ramalhete, Spengler, et al., 2011c).

The bacterial quorum sensing (QS) is a cell-to-cell communication system that is based on chemical signals, namely, autoinducers (Als). In Gram-negative bacteria, the most common Al is the $\mathrm{N}$-acyl homoserine lactone (AHL; Varga et al., 2011). EPs and QS signals play an important role in the development of bacterial virulence. The QS system and the Als are able to influence the expression of transporter genes. These EPs have the ability to transport AI molecules to the external environment of bacteria, thus facilitating cell-to-cell communication (Spengler, Kincses, Gajdács, \& Amaral, 2017).

Cleistochlamys kirkii (Benth) Oliv. (Annonaceae) is an African medicinal plant traditionally used in Mozambique for the treatment of wound infections, tuberculosis, and rheumatism (Verzár \& Petri, 1987).

Previously, in a research for antimicrobial compounds from African medicinal plants (Cabral et al., 2015; Kolaczkowski et al., 2010; Madureira, Ramalhete, Mulhovo, Duarte, \& Ferreira, 2012; Pereira et al., 2016; Ramalhete et al., 2010), bioassay-guided fractionation of the methanol extract of the root barks of $C$. kirkii led to the isolation of several compounds with different scaffolds. Among them, $C$-benzylated flavanones, namely, dichamanetin and the $a, \beta$-unsaturated lactone (-)-cleistenolide, have shown relevant antibacterial activity against Gram-positive bacteria, including drug-resistant strains (Pereira et al., 2016). Moreover, in the combination with $\beta$-lactam antibiotics and vancomycin, polycarpol bearing a triterpenic scaffold exhibited a strong synergistic effect against Gram-positive resistant strains. In this study, polycarpol (1) and C-benzylated flavanones 2-4 and a heptane derivative (5) were further investigated for their ability as both EP and QS inhibitors of the efflux systems of Gram-negative and Gram-positive bacteria. Furthermore, the ability of compounds 2 and 4 to potentiate the effect of tetracycline and the fluoroquinolone antibiotic ciprofloxacin on methicillin-susceptible and methicillin-resistant S. aureus (MRSA) strains was also described.

\section{2 | MATERIALS AND METHODS}

\section{1 | Compounds tested}

Triterpene polycarpol (1), C-benzylated flavanones chamanetin (2), isochamanetin (3), dichamanetin (4), and the heptane derivative acetylmelodorinol (5; Figure 1) were isolated from the methanol extract of the root barks of $C$. kirkii, as it has previously been described (Pereira et al., 2016). The purity of all the compounds was higher than 95\% based on high-performance liquid chromatography analysis and nuclear magnetic resonance spectroscopy. The compounds were dissolved in dimethyl sulfoxide (DMSO).

\section{2 | Reagents and media}

Promethazine (PMZ; EGIS), ethidium bromide (EB), verapamil, tetracycline-hydrochloride (TET), ciprofloxacin-hydrochloride (CIP), and Luria-Bertani (LB) broth, and LB agar were purchased from SigmaAldrich Chemie GmbH (Steinheim, Germany). The modified LB medium $\left(\mathrm{LB}^{*}\right)$ was prepared from yeast extract $5 \mathrm{~g} / \mathrm{L}$, tryptone $10 \mathrm{~g} / \mathrm{L}, \mathrm{NaCl}$ $10 \mathrm{~g} / \mathrm{L}, \mathrm{K}_{2} \mathrm{HPO}_{4} 1 \mathrm{~g} / \mathrm{L}, \mathrm{MgSO}_{4} \times 7 \mathrm{H}_{2} \mathrm{O} 0.3 \mathrm{~g} / \mathrm{L}$, and FeNaEDTA

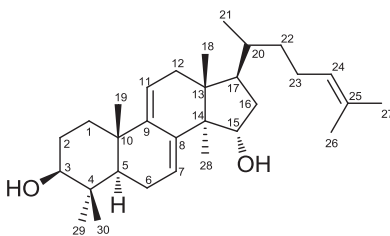

Polycarpol (1)

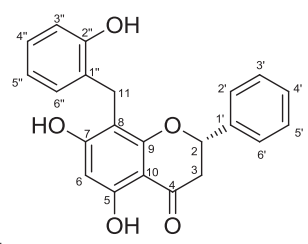

Chamanetin (2)<smiles>O=C1C[C@@H](c2ccccc2)Oc2cc(O)c(Cc3ccccc3O)c(O)c21</smiles>

Isochamanetin (3)<smiles>CC(C)(C)CCCCCO</smiles>

Dichamanetin (4)

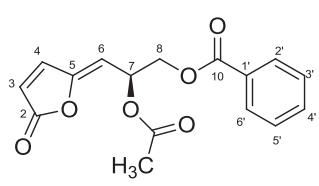

Acetylmelodorinol (5)
FIGURE 1 Chemical structures of compounds 1-5 
$36 \mathrm{mg} / \mathrm{L}$. In case of modified LB* agar, the LB* medium was supplemented with agar $20 \mathrm{~g} / \mathrm{L}$ (Difco). pH was adjusted to 7.2. Tryptic soy broth (TSB), tryptic soy agar, and Mueller-Hinton $(\mathrm{MH})$ broth were purchased from Scharlau Chemie S. A. (Barcelona, Spain).

\section{3 | Bacterial strains}

Compounds were evaluated against the Gram-negative wild-type Escherichia coli K-12 AG100 strain [argE3 thi-1 rpsL xyl mt $\Delta$ (gal-uvrB) supE44], expressing the AcrAB-TolC EP at its basal level and its AcrAB-TolC-deleted mutant E. coli AG100 A strain. These strains were kindly provided by Prof. Dr. Hiroshi Nikaido (Department of Molecular and Cell Biology and Chemistry, University of California, Berkeley, CA, USA).

The compounds were further evaluated against two Gram-positive strains, S. aureus American Type Culture Collection (ATCC) 25923 , used as the methicillin-susceptible reference strain, and the methicillin and ofloxacin-resistant S. aureus 272123 clinical isolate, which was kindly provided by Prof. Dr. Leonard Amaral (Institute of Hygiene and Tropical Medicine, Lisbon, Portugal).

For QS tests, the following strains were used: Chromobacterium violaceum 026 (CV026) as sensor strain and Enterobacter cloaceae 31298 as AHL producer strain (a clinical isolate from a wound). When C. violaceum reaches a high cell density, it produces a purple pigment, namely, violacein (Ballantine, Beer, Crutchley, Dodd, \& Palmer, 1958).

\subsection{Determination of minimum inhibitory concentrations by microdilution method}

The minimum inhibitory concentrations (MICs) of compounds were determined according to the Clinical and Laboratory Standard Institute guidelines (2017) in three independent assays. The solvent DMSO had no antibacterial effect.

\subsection{Interaction between antibiotics and compounds}

The combined effect of compounds and antibiotics on the growth inhibition of S. aureus was evaluated by the checkerboard method. Twofold serial dilutions of antibiotics were prepared in $\mathrm{MH}$ broth on the horizontal rows of microtiter plate and then cross-diluted vertically by twofold serial dilutions of the compounds (Wolfart et al., 2006). For this assay, only the compounds with well-defined MIC values could be used. Consequently, the combination assays were carried out on methicillin-susceptible and MRSA strains. The dilutions of the antibiotics (TET or CIP) were made in a horizontal direction in $100 \mu \mathrm{l}$, and the dilutions of compounds were made vertically in the microtiter plate in $50 \mu \mathrm{l}$. After the dilution of an overnight culture, bacterial cells were resuspended in $\mathrm{MH}$ medium containing $1 \times 10^{4}$ cells and distributed into each well. The plates were incubated for $18 \mathrm{hr}$ at $37^{\circ} \mathrm{C}$. The cell growth rate was determined after MTT (3-(4,5-dimethylthiazol-2-yl)2,5-diphenyltetrazolium bromide) staining, as described elsewhere (Wolfart et al., 2006). The combination index (Cl) values at $90 \%$ growth inhibition $\left(E D_{90}\right)$ were determined by using CompuSyn software to plot 4 or 5 data points for each ratio (www.combosyn.com, ComboSyn, Inc., Paramus, NJ, USA). Cl values were calculated by means of the median-effect equation, where $\mathrm{Cl}<1, \mathrm{Cl}=1$, and $\mathrm{Cl}>1$ represent synergism, an additive effect (or no interaction), and antagonism, respectively (Chou \& Martin, 2005).

\subsection{Real-time accumulation assay by Roche LightCycler real-time thermocycler}

The activity of compounds on the real-time accumulation of EB was assessed by the automated EB method (Viveiros et al., 2008) using a LightCycler real-time thermocycler (LightCycler 1.5, Roche, Indianapolis, IN, USA). Briefly, an aliquot of an overnight culture of the $S$. aureus strain in TSB medium was transferred to fresh TSB medium, and it was incubated until it reached an optical density (OD) of 0.6 at $600 \mathrm{~nm}$. In case of E. coli, the medium used in the assay was LB broth; the preparation of the inoculum was similar to the one of $S$. aureus. The cells were washed with phosphate-buffered saline (PBS; $\mathrm{pH}$ 7.4) and centrifuged at $13,000 \times g$ for $3 \mathrm{~min}$, the pellets were resuspended in PBS $(\mathrm{pH} 7.4)$, and the OD was adjusted to 0.6 at $600 \mathrm{~nm}$. The compounds were added individually at different concentrations at $\mathrm{MIC} / 2, \mathrm{MIC} / 3$, $\mathrm{MIC} / 4$, or $\mathrm{MIC} / 5$ (in double concentrated form) to the EB solution in PBS. The final concentration of EB was based on the MIC and the fluorescent signal produced by this amount of EB. In case of $S$. aureus strains, the concentration of EB was $0.5 \mu \mathrm{g} / \mathrm{ml}$, for E. coli AG100 $1 \mu \mathrm{g} / \mathrm{ml}$, and in case of E. coli AG100 A, it was $0.25 \mu \mathrm{g} / \mathrm{ml}$. Then, $10 \mu$ of the EB solution containing the compound was transferred into standard glass capillary tubes of $20 \mu \mathrm{l}$ maximum volume (Roche), and $10 \mu \mathrm{l}$ of bacterial suspension (OD of 0.6 at $600 \mathrm{~nm}$ ) was added to the capillaries. The capillaries containing the samples were placed into the carousel (Roche), and the fluorescence was monitored at the FL-2 channel in every minute on a real-time basis.

From the real-time data, the activity of the compound, namely, the relative final fluorescence index (RFI) of the last time point (minute 30) of the EB accumulation assay, was calculated according to the following formula:

$$
R F I=\frac{R F_{\text {treated }}-R F_{\text {untreated }}}{R F_{\text {untreated }}}
$$

where $R F_{\text {treated }}$ is the relative fluorescence at the last time point of $E B$ retention curve in the presence of an inhibitor and $R F_{\text {untreated }}$ is the relative fluorescence at the last time point of the $E B$ retention curve of the untreated control having the solvent control (DMSO). Verapamil was applied as positive control on Gram-positive strains, and PMZ was used on Gram-negative strains.

\section{7 | Assay for quorum sensing inhibition}

LB* $^{*}$ was used for these experiments. The sensor strain $C$. violaceum 026 and the $\mathrm{AHL}$ producer strains E. cloaceae 31298 were inoculated as parallel lines and incubated at room temperature $\left(20^{\circ} \mathrm{C}\right)$ for 24-48 hr. QS inhibition was monitored by the agar diffusion method. Filter paper discs (7.0 mm in diameter) were impregnated with $10 \mu \mathrm{l}$ of stock solutions (10 $\mathrm{mM}$ ) of the compounds in DMSO. The discs were placed between the parallel lines of the sensor and the $\mathrm{AHL}$ producer strains on the surface of the nutrient agar. The plates were incubated at room temperature for another $24-48 \mathrm{hr}$, and the interactions between the strains and compounds were evaluated for the 
reduction in the size of the zone of pigment production and the zone of growth inhibition of the affected strains, in millimeters. PMZ was applied as positive control (Varga et al., 2011).

\section{8 | Expression analyses of genes by real-time reverse transcriptase quantitative polymerase chain reaction}

S. aureus ATCC 25923 and S. aureus 272123 strains were cultured in TSB broth and were incubated overnight at $37{ }^{\circ} \mathrm{C}$ with shaking. On the day of RNA isolation, the bacterial suspensions (OD of 0.6 at $600 \mathrm{~nm}$ ) were transferred to $10-\mathrm{ml}$ tubes in 3-ml aliquots, and $5 \mu \mathrm{M}$ of compound 2 or $0.5 \mu \mathrm{M}$ of compound 4 was added to the tubes, which were incubated at $37^{\circ} \mathrm{C}$. After $4 \mathrm{hr}$ of culturing, the tubes were centrifuged at $12,000 \times \mathrm{g}$ for $2 \mathrm{~min}$. Pellets were suspended in $100 \mu \mathrm{l}$ Tris-EDTA buffer containing $1 \mathrm{mg} / \mathrm{ml}$ lysozyme by vigorous vortexing, and they were incubated at $37^{\circ} \mathrm{C}$ for $10 \mathrm{~min}$. The total RNA was isolated in an RNase-free environment using the NucleoSpin RNA kit (Macherey Nagel, Düren, Germany) according to the manufacturer's instructions. Purified RNA was stored in RNase-free water in nuclease-free collection tubes and was maintained at $-20^{\circ} \mathrm{C}$ until quantification was performed. The concentration of the extracted RNA templates was assessed by spectrophotometry at $260 \mathrm{~nm}$. Expression of the EP genes norA and mepA was studied by reverse transcription of the total RNA. The data obtained for gene targets were normalized against the $S$. aureus $16 \mathrm{~S}$ ribosomal RNA measured in the same sample. The primers (Couto, Costa, Viveiros, Martins, \& Amaral, 2008) used in the assay were the following:

1. Sequence $\left(5^{\prime}-3^{\prime}\right)$ of norA (246 bp)

2. Sequence $\left(5^{\prime}-3^{\prime}\right)$ of mepA (198 bp)
TCGTCTTAGCGTTCGG TTTA (Fw) TCCAGTAACCATCGGC AATA (Rv) TGCTGCTGCTCTGTTC TTTA (Fw) GCGAAGTTTCCATAAT GTGC (Rv)

AGAGTTTGATCMTGGC TCAG (FW) GWATTACCGCG GCKGCTG (Rv)

Real-time quantification of the RNA templates by real-time onestep reverse transcriptase quantitative polymerase chain reaction was performed in a CFX96 Touch real-time PCR detection system (Bio-Rad,
Hercules, CA, USA), and the manufacturer's recommendations of the SensiFAST ${ }^{\mathrm{T}}$ SYBR No-ROX One-Step Kit (Bioline GmbH, Luckenwalde, Germany) were strictly adhered to. Briefly, each well of the 96-well microtiter plates in a final volume of $20 \mu \mathrm{l}$ contained $10 \mu \mathrm{l}$ of the $2 \times$ SensiFAST ${ }^{\mathrm{TM}}$ SYBR No-ROX One-Step Mix, $0.2 \mu \mathrm{l}$ reverse transcriptase, $0.4 \mu \mathrm{l}$ RiboSafe RNase Inhibitor, $5.4 \mu \mathrm{l}$ diethyl pyrocarbonate-treated water, $500 \mathrm{nM}$ of each primer, and approximately $20 \mathrm{ng}$ of the total RNA in RNAase-free water. Thermal cycling was initiated with a denaturation step of $5 \mathrm{~min}$ at $95^{\circ} \mathrm{C}$, followed by 40 cycles, each of $10 \mathrm{~s}$ at $95^{\circ} \mathrm{C}$, $30 \mathrm{~s}$ at $57^{\circ} \mathrm{C}$, and $20 \mathrm{~s}$ at $72{ }^{\circ} \mathrm{C}$.

\section{3 | RESULTS}

\section{1 | In vitro antibacterial activity of compounds}

Compounds (1-5) were assessed for their antibacterial activity against methicillin-susceptible S. aureus ATCC 25923, and the methicillin- and ofloxacin-resistant S. aureus 272123 clinical isolate. Wild-type E. coli K-12 AG100 strain, and E. coli AG100 A strain, overexpressing and lacking the AcrAB-TolC EP system, respectively, were used as Gramnegative models. In addition, the antibacterial activity of the compounds was tested on QS strains C. violaceum and E. cloaceae.

Concerning the antibacterial effect of the compounds, chamanetin (2) and dichamanetin (4) had a potent antibacterial effect on the S. aureus strains. MIC value of compound 2 was $12.5 \mu \mathrm{M}$ on reference S. aureus; however, the MIC of the methicillin- and ofloxacin-resistant strain was $25 \mu \mathrm{M}$. Compound 4 was the most effective flavanone because its MIC value on S. aureus ATCC 25923 was $0.8 \mu \mathrm{M}$; furthermore, on the methicillin-resistant strain, it was $1.56 \mu \mathrm{M}$.

The compounds had no antibacterial effect on the Gram-negative E. coli AG100, AG100 A, C. violaceum, and E. cloaceae strains.

\subsection{Combination effects of chamanetin (2) and dichamanetin (4) with antibiotics}

The type of interaction between the antibacterial C-benzylated flavanones 2 and 4 and tetracycline and the fluoroquinolone antibiotic ciprofloxacin was evaluated on methicillin-susceptible (ATCC 25923) and MRSA strains by the checkerboard assay. The results are presented in Tables $1 \mathrm{a}$ and $1 \mathrm{~b}$ as $\mathrm{Cl}$ values. $\mathrm{Cl}$ values $<1$ indicate a synergistic interaction between the compound and the antibiotic (Chou \& Martin, 2005). As it can be observed, the combined effect of TET and compound 2 or 4 on S. aureus ATCC 25923 resulted in synergism. The most effective ratio of antibiotic and compound was 1:20

TABLE 1a Combination assays on Staphylococcus aureus ATCC 25923 strain

\begin{tabular}{lllll} 
Staphylococcus aureus ATCC 25923 & & & & \\
\hline Combination & Best ratio & Cl at ED $_{90}$ & SD (+/-) & Interaction \\
\hline Tetracycline + chamanetin (2) & $1: 20$ & 0.63786 & 0.13419 & Synergism \\
Tetracycline + dichamanetin (4) & $1: 1$ & 0.42093 & 0.10354 & Synergism \\
Ciprofloxacin + chamanetin (2) & $1.3: 12.5$ & 0.81577 & 0.23974 & Slight synergism \\
Ciprofloxacin + dichamanetin (4) & $1.3: 1$ & 0.68615 & 0.27953 & Synergism
\end{tabular}

Note. Starting concentration of tetracycline: $5.2 \mu \mathrm{M}$; ciprofloxacin: $2.6 \mu \mathrm{M}$; and compound 2: $25 \mu \mathrm{M}$ and compound 4: $2 \mu \mathrm{M}$. ATCC = American Type Culture Collection; $\mathrm{Cl}=$ combination index. 
TABLE 1b Combination assays on MRSA 272123 strain

\begin{tabular}{lllll} 
Staphylococcus aureus $\mathbf{2 7 2 1 2 3}$ & & & & \\
\hline Combination & Best ratio & Cl at ED 90 & SD (+/-) & Interaction \\
\hline Tetracycline + chamanetin (2) & $6: 25$ & 1.4595 & 0.29390 & Antagonism \\
Tetracycline + dichamanetin (4) & $100: 1$ & 0.59402 & 0.34521 & Synergism \\
Ciprofloxacin + chamanetin (2) & $13: 8$ & 0.85030 & 0.21648 & Slight synergism \\
Ciprofloxacin + dichamanetin (4) & $32: 1$ & 1.35064 & 0.24946 & Moderate antagonism
\end{tabular}

Note. Starting concentration of tetracycline: $100 \mu \mathrm{M}$; ciprofloxacin: $64 \mu \mathrm{M}$; and compound 2: $50 \mu \mathrm{M}$ and compound 4: $3 \mu \mathrm{M}$. Ratio: antibiotic and tested compound $(\mu \mathrm{M}) . \mathrm{Cl}<1, \mathrm{Cl}=1$, and $\mathrm{Cl}>1$ represent synergism, an additive effect (or no interaction), and antagonism, respectively. $\mathrm{Cl}=$ combination index; MRSA = methicillin-resistant Staphylococcus aureus.

and 1:1, respectively. Similarly, CIP also acted synergistically with compounds 2 and 4 , being the most active ratio of antibiotic and compound 1.3:12.5 and 1.3:1, respectively (Table 1a).

Against the MRSA strain, compound 2 showed antagonistic effect with TET and slight synergism with CIP. The interactions of compound 4 with TET and CIP on the MRSA strain were synergism and moderate antagonism, respectively (Table $1 \mathrm{~b}$ ).

\section{3 | Efflux pump-inhibiting activity}

The EB accumulation assay provides information about the intracellular accumulation of the general EP substrate EB. A potential EPI increases the fluorescence level of $E B$ because of its accumulation within the bacterial cell. The EP-inhibiting activity of the compounds was compared on the basis of the RFI of the real-time accumulation curves in Gram-positive and Gram-negative strains (Figure 2a). In case of real-time EB accumulation by the LightCycler thermocycler, the amount of EB accumulated by cells is higher if the difference between $R F_{\text {treated }}$ and $R F_{\text {untreated }}$ is greater; therefore, the degree of inhibition of the EP system by the compound becomes greater.

As shown in Figure 2a, compounds 2, 3, and 5 had EP-inhibiting activity compared with verapamil (RFI: 0.29) on the S. aureus ATCC 25923 strain, and the most active compound was compound 2 . However, compounds 1-5 had no EPI activity on the MRSA strain at the concentrations applied in the assay.

Concerning the inhibitory activity on Gram-negatives, triterpene polycarpol (1) and acetylmelodorinol (5) compared with the PMZ (RFI: 0.15) could inhibit the AcrAB-TolC system of E. coli AG100. Compound 1 proved to be the most effective EPI (Figure 2a). On the basis of the real-time accumulation data, compounds 1-5 had no effect on the E. coli AG100 A strain lacking the AcrAB-TolC pump.

\subsection{Anti-quorum sensing activity}

The QS inhibition activity of compounds was defined measuring the colorless zone around the disc on C. violaceum as described previously (Varga et al., 2011). Compounds 1, 2, 4, and 5 were able to inhibit effectively the QS between CVO26 and E. cloaceae compared with the positive control PMZ (Table 2).

\section{5 | Relative expression of efflux pump genes}

In order to evaluate the effect of compounds on the relative expression of EP genes in both $S$. aureus strains, the most effective compounds $\mathbf{2}$ and $\mathbf{4}$ were selected for gene expression studies. In the real-time quantitative RT-PCR assay, the genes of NorA and MepA transporters were investigated. As shown in Figure $2 \mathrm{bA}$, compound 2 at $5 \mu \mathrm{M}$ significantly up-regulated the expression of norA and mepA genes after $4 \mathrm{hr}$ of exposure in the MRSA strain. Compound 4 at $0.5 \mu \mathrm{M}$ also significantly up-regulated both EP genes after $4 \mathrm{hr}$ of exposure in the MRSA as presented in Figure $2 \mathrm{bB}$. In the $S$. aureus ATCC strain, the expression level of the mepA gene was not influenced; nevertheless, the norA gene was significantly up-regulated by compounds 2 (19.84-fold increase) at $5 \mu \mathrm{M}$ and 4 (2.39-fold increase) at $0.5 \mu \mathrm{M}$ (data not shown).

\section{4 | DISCUSSION}

Natural compounds isolated from plants represent a valuable source of new antibacterial agents. When analyzing the results, the potent antibacterial activity found for dichamanetin (4) and also the significant activity of chamanetin (2) corroborated our previous studies on this set of rare C-benzylated flavanones (Pereira et al., 2016). The strongest activity of dichamanetin (4), when compared with chamanetin (2), seems to be due to its higher lipophilic character resulting from the extra benzyl group at C-6. In contrast to chamanetin (2), isochamanetin (3), differing only in the position of the benzyl group, was inactive at the concentration tested. Thus, besides the importance of lipophilicity, the presence of a benzyl moiety at C-8 appears to play a decisive role in the antibacterial activity of this type of compounds.

In the combination assays, chamanetin (2) and dichamanetin (4) had synergistic activity with tetracycline and ciprofloxacin on the S. aureus ATCC 25923 strain. Furthermore, on the MRSA strain, dichamanetin (4) and chamanetin (2), combined with tetracycline and ciprofloxacin, respectively, also showed synergism, which indicates that these compounds could be potential adjuvants in the therapy.

Besides having an antibacterial effect, both compounds (2 and 4) could inhibit the activity of EPs, they were QS inhibitors, and they significantly increased the expression of EP genes norA and mepA after $4 \mathrm{hr}$ of exposure in the MRSA strain. Furthermore, the NorA and MepA pumps of the MRSA strain could not be inhibited because of the overexpression of these pumps. The change in gene expression could be due to the stress response against compounds 2 and 4 because these compounds as potential noxious agents for $S$. aureus had to be extruded from the cytoplasm as soon as possible. This stress response can be the explanation for the up-regulation of the EP genes after $4 \mathrm{hr}$. The difference between MRSA and ATCC is due to the overexpression 
(a)

\begin{tabular}{|c|c|c|c|c|c|c|}
\hline \multirow{2}{*}{ Compound } & \multicolumn{3}{|c|}{ E. coli AG100 } & \multicolumn{3}{c|}{ S. aureus ATCC 25923 } \\
\cline { 2 - 7 } & $\begin{array}{c}\text { MIC } \\
(\boldsymbol{\mu M})\end{array}$ & $\begin{array}{c}\text { Concentration } \\
(\mu \mathrm{M})\end{array}$ & RFI & $\begin{array}{c}\text { MIC } \\
(\mu \mathrm{M})\end{array}$ & $\begin{array}{c}\text { Concentration } \\
(\mu \mathrm{M})\end{array}$ & RFI \\
\hline $\mathbf{1}$ & $>100$ & 50 & 0.484 & $>100$ & 25 & -0.035 \\
\hline $\mathbf{2}$ & $>100$ & 50 & -0.414 & 12.5 & 5 & -0.267 \\
\hline $\mathbf{3}$ & $>100$ & 50 & -0.032 & $>100$ & 25 & 0.174 \\
\hline $\mathbf{4}$ & $>100$ & 50 & -0.643 & 0.8 & 0.5 & -0.151 \\
\hline $\mathbf{5}$ & $>100$ & 50 & 0.161 & $>100$ & 25 & 0.139 \\
\hline
\end{tabular}

(b)
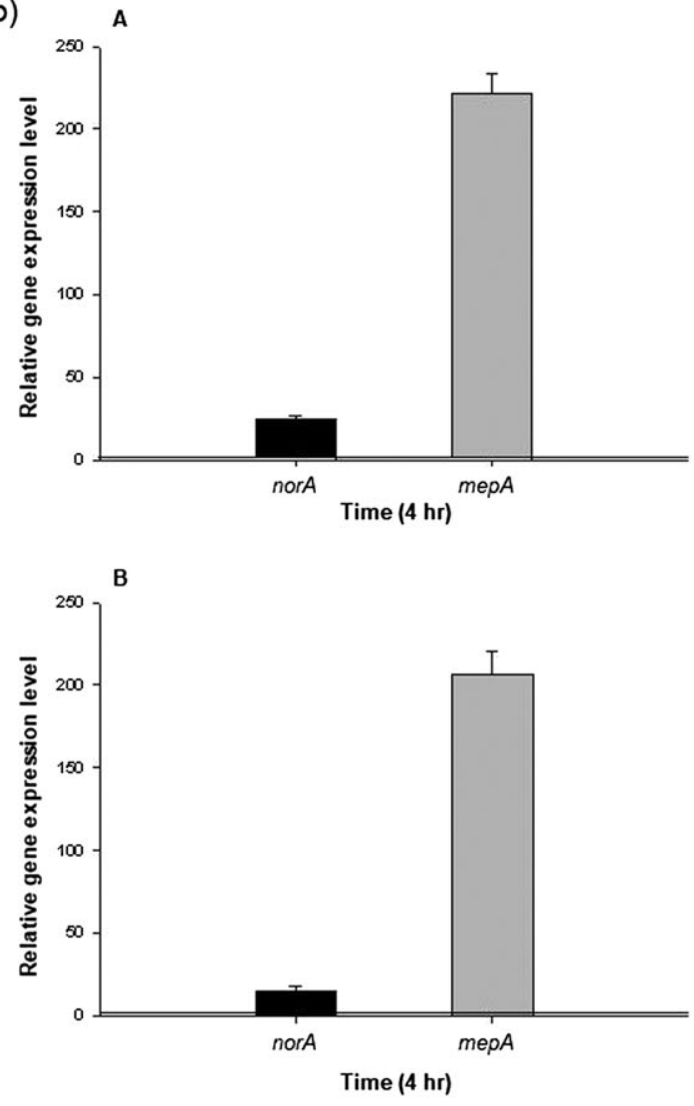

TABLE 2 Inhibitory effects of compounds 1-5 on QS signal transmission

\begin{tabular}{ll} 
Compound & QS inhibition zone in $\mathrm{mm}$ \\
\hline 1 & 51 \\
2 & 50 \\
\hline 3 & - \\
4 & 53 \\
\hline 5 & 52 \\
\hline Promethazine & 46 \\
\hline
\end{tabular}

Note. Ten microliters of $10 \mathrm{mM}$ stock solution was added into the filter paper discs (10 $\mu \mathrm{M}$ per disc), and the colorless zone around the disc measured on Chromobacterium violaceum was measured after incubation for 24-48 $\mathrm{hr}$ at room temperature. QS = quorum sensing.
FIGURE 2 The minimum inhibitory concentration (MIC) and efflux pump modulating effect of compounds 1-5. (a) Relative final fluorescence index (RFI) for the effect of compounds 1-5 on the AcrAB-TolCexpressing Escherichia coli $\mathrm{AG} 100$ and Staphylococcus aureus American Type Culture Collection (ATCC) 25923 strains. (b) Relative gene expression levels of norA and mepA genes in the presence of (A) chamanetin (2) and (B) dichamanetin (4) in methicillin resistant Staphylococcus aureus (MRSA) 272123, after 4-hr exposure. The line denotes the threshold value, which was set at a twofold increase in transcripts of the mepA gene in the resistant strain and it has low expression level in the ATCC strain. Compounds 2 and $\mathbf{4}$ increased the expression of mepA gene in the MRSA, but in the ATCC strain, these compounds did not influence the expression level of mepA. It has been demonstrated by other studies that the overexpression of EPs confers a fitness cost for the organism, for example, a resistant isolate overexpressing EPs shows reduced production of virulence determinants. Usually the overexpression of pump genes is often related to global effects on bacterial physiology influencing virulence (Ledda et al., 2017).

In Gram-negatives, compounds 1-5 had no antibacterial activity. Polycarpol (1) was the most effective EPI, inhibiting the AcrAB-TolC transport system in the E. coli AG100 strain. The AcrAB-TolC system belongs to the resistance nodulation division transporters, utilizing the proton motive force to extrude toxic agents out of the bacterial 
cell. Since compound 1 had no EPI effect on the AcrAB-TolC pumpdeleted E. coli strain, it may have a direct EPI effect on the AcrAB-TolC transporter system. The effect of polycarpol could be due to its high lipophilicity (Pereira et al., 2016), which can increase the membrane permeability of bacteria.

In addition to flavanones 2 and 4 , polycarpol (1) and acetylmelodorinol (5) were also able to inhibit effectively the bacterial communication, suggesting that they could be applied as anti-QS agents.

\section{5 | CONCLUSIONS}

To summarize our findings, C. kirkii constituents, chamanetin (2) and dichamanetin (4), inhibited the growth of both $S$. aureus strains. The three flavanones tested (2-4) increased the accumulation of the EP substrate EB on sensitive $S$. aureus strain, and compounds 1, 2, 4, and 5 prevented the cell-to-cell communication. Polycarpol (1) was an effective inhibitor of the AcrAB-TolC system of $E$. coli, which might be explained by its interference with membrane permeability and modulation of the function of the pump. Dichamanetin (4) and chamanetin (2) showed synergistic effect on MRSA and sensitive $S$. aureus strains implying that they could restore and increase the efficacy of antibiotics, especially in MDR infections. It can be assumed that the advantageous properties of $C$. kirkii constituents can influence the QS system and operation of EPs decreasing virulence and antibiotic resistance (Varga et al., 2011).

According to the results, the most active compounds, chamanetin (2) and dichamanetin (4), could be possible resistance modifiers because they possess antibacterial, EPI, and anti-QS properties; moreover, these compounds might be used as adjuvants in the antibiotic therapy because they may be able to reduce the bacterial virulence. Furthermore, they can potentiate the activity of antibiotics.

\section{ACKNOWLEDGEMENTS}

This research was supported by the European Union and the State of Hungary and by the Portuguese Foundation for Science and Technology (FCT), Projects PTDC/QEQ-MED/0905/2012 and UID/DTP/ 04138/2013, and co-financed by the European Social Fund in the framework of TÁMOP 4.2.4. A/2-11-1-2012-0001 "National Excellence Program." This study was supported by the GINOP-2.3.2-152016-00012 project (University of Szeged, Hungary), and Gabriella Spengler was supported by the János Bolyai Research Scholarship of the Hungarian Academy of Sciences. Annamária Kincses was supported by the ÚNKP-17-3 New National Excellence Program of the Ministry of Human Capacities of Hungary. The authors thank the Portuguese Embassy in Mozambique, as well as the Portuguese Office of International Affairs, for plant transport.

\section{CONFLICT OF INTEREST}

The authors declare no conflict of interest.

\section{ORCID}

Maria-José U. Ferreira (D) http://orcid.org/0000-0002-8742-1486
Gabriella Spengler (D) http://orcid.org/0000-0001-8085-0950

\section{REFERENCES}

Aparna, V., Dineshkumar, K., Mohanalakshmi, N., Velmurugan, D., \& Hopper, W. (2014). Identification of natural compound inhibitors for multidrug efflux pumps of Escherichia coli and Pseudomonas aeruginosa using in silico high-throughput virtual screening and in vitro validation. PLoS One, 9, e101840.

Ballantine JA, Beer RJS, Crutchley DJ, Dodd GM, Palmer DR. 1958. The synthesis of violacein and related compounds. Proc Chem Soc 232-33.

Balogh, E. P., Mosolygó, T., Tiricz, H., Szabó, A. M., Karai, A., Kerekes, F., .. Burián, K. (2014). Anti-chlamydial effect of plant peptides. Acta Microbiol Immunol, 61, 229-239.

Cabral, V., Luo, X., Junqueira, E., Costa, S. S., Mulhovo, S., DuarteA, C. I., ... Ferreira, M. J. U. (2015). Enhancing activity of antibiotics against Staphylococcus aureus: Zanthoxylum capense constituents and derivatives. Phytomedicine, 22, 469-476.

Chou, T. C., \& Martin, N. (2005). Compusyn for drug combinations: PC software and user's guide: A Computer program for quantitation of synergism and antagonism in drug combinations, and the determination of $I C_{50}$ and $E D_{50}$ and $L D_{50}$ values. Paramus, NJ, USA: ComboSyn Inc.

Clinical and Laboratory Standard Institute guidelines (2017). Accessed on 24 July 2017. Retrieved from http://clsi.org/

Costa, S. S., Viveiros, M., Amaral, L., \& Couto, I. (2013). Multidrug efflux pumps in Staphylococcus aureus: An update. Open Microbiol J, 7, 59-71.

Couto, I., Costa, S. S., Viveiros, M., Martins, M., \& Amaral, L. (2008). Effluxmediated response of Staphylococcus aureus exposed to ethidium bromide. The Journal of Antimicrobial Chemotherapy, 62, 504-513.

Hintz, T., Matthews, K. K., \& Di, R. (2015). The use of plant antimicrobial compounds for food preservation. BioMed Research International, 2015, 246264.

Klyachko, K. A., Schuldiner, S., \& Neyfakh, A. A. (1997). Mutations affecting substrate specificity of the Bacillus subtilis multidrug transporter Bmr. Journal of Bacteriology, 179, 2189-2193.

Kolaczkowski, M., Kolaczkowska, A., Środa, K., Ramalhete, C., Michalak, K., Mulhovo, S., \& Ferreira, M. J. U. (2010). Substrates and modulators of the multidrug transporter Cdr1p of Candida albicans in antifungal extracts of medicinal plants. Mycoses, 53, 305-310.

Ledda, A., Price, J. R., Cole, K., Llewelyn, M. J., Kearns, A. M., Crook, D. W. ... Didelot, X. (2017). Re-emergence of methicillin susceptibility in a resistant lineage of Staphylococcus aureus. The Journal of Antimicrobial Chemotherapy, 72, 1285-1288.

Madureira, A. M., Ramalhete, C., Mulhovo, S., Duarte, A., \& Ferreira, M. J. U. (2012). Antibacterial activity of some African medicinal plants used traditionally against infectious diseases. Pharmaceutical Biology, 50, 481-489.

Pereira, F., Madureira, A. M., Sancha, S., Mulhovo, S., Luo, X., Duarte, A., \& Ferreira, M. J. U. (2016). Cleistochlamys kirkii chemical constituents: Antibacterial activity and synergistic effects against resistant Staphylococcus aureus strains. Journal of Ethnopharmacology, 178, 180-187.

Ramalhete, C., Da Cruz, F. P., Lopes, D., Mulhovo, S., Rosário, V. E., Prudêncio, M., \& Ferreira, M. J. U. (2011a). Triterpenoids as inhibitors of erythrocytic and liver stages of Plasmodium infections. Bioorganic Med Chem, 19, 7474-7481.

Ramalhete, C., Lopes, D., Molnár, J., Mulhovo, S., Rosário, V. E., \& Ferreira, M. J. U. (2011b). Karavilagenin C derivatives as antimalarials. Bioorganic Med Chem, 19, 330-338.

Ramalhete, C., Lopes, D., Mulhovo, S., Molnár, J., Rosário, V. E., \& Ferreira, M. J. U. (2010). New antimalarials with a triterpenic scaffold from Momordica balsamina. Bioorganic Med Chem, 18, 5254-5260.

Ramalhete, C., Spengler, G., Martins, A., Martins, M., Viveiros, M., Mulhovo, S., ... Amaral, L. (2011c). Inhibition of efflux pumps in methicillin-resistant Staphylococcus aureus and Enterococcus faecalis resistant strains by triterpenoids from Momordica balsamina. International Journal of Antimicrobial Agents, 37, 70-74. 
Spengler, G., Kincses, A., Gajdács, M., \& Amaral, L. (2017). New roads leading to old destinations: Efflux pumps as targets to reverse multidrug resistance in bacteria. Molecules, 22, E468.

Stavri, M., Piddock, L. J., \& Gibbons, S. (2007). Bacterial efflux pump inhibitors from natural sources. The Journal of Antimicrobial Chemotherapy, 59, 1247-1260.

Stermitz, F. R., Lorenz, P., Tawara, J. N., Zenewicz, L. A., \& Lewis, K. (2000). Synergy in a medicinal plant: Antimicrobial action of berberine potentiated by $5^{\prime}$-methoxyhydnocarpin, a multidrug pump inhibitor. Proceedings of the National Academy of Sciences of the United States of America, 97, 1433-1437.

Varga, G. Z., Szabó, M. A., Schelz, Zs., Szegedi, E., Amaral, L., \& Molnár, J. (2011). Quorum sensing inhibition by phenothiazines and related compounds. Lett Drug Design Discovery, 8, 133-137.

Verzár, R., \& Petri, G. (1987). Medicinal plants in Mozambique and their popular use. Journal of Ethnopharmacology, 19, 67-80.

Viveiros, M., Martins, A., Paixão, L., Rodrigues, L., Martins, M., Couto, I., ... Amaral, L. (2008). Demonstration of intrinsic efflux activity of
Escherichia coli K-12 AG100 by an automated ethidium bromide method. International Journal of Antimicrobial Agents, 31, 458-462.

Webber, M. A., \& Piddock, L. J. (2003). The importance of efflux pumps in bacterial antibiotic resistance. The Journal of Antimicrobial Chemotherapy, 51, 9-11.

Wolfart, K., Spengler, G., Kawase, M., Motohashi, N., Molnár, J., Viveiros, M., \& Amaral, L. (2006). Synergistic interaction between proton pump inhibitors and resistance modifiers: Promoting effects of antibiotics and plasmid curing. In Vivo, 20, 367-372.

How to cite this article: Kincses A, Varga B, Csonka Á, et al. Bioactive compounds from the African medicinal plant Cleistochlamys kirkii as resistance modifiers in bacteria. Phytotherapy Research. 2018;1-8. https://doi.org/10.1002/ ptr.6042 


\section{III.}




\title{
Selenocompounds as Novel Antibacterial Agents and Bacterial Efflux Pump Inhibitors
}

\author{
Tímea Mosolygó ${ }^{1} @$, Annamária Kincses ${ }^{1}$, Andrea Csonka ${ }^{1,2}$, Ádám Szabó Tönki ${ }^{1}$, \\ Karolina Witek ${ }^{3}$, Carmen Sanmartín 4,5, Małgorzata Anna Marć ${ }^{3,6}$, Jadwiga Handzlik ${ }^{3}$, \\ Katarzyna Kieć-Kononowicz ${ }^{3}$, Enrique Domínguez-Álvarez ${ }^{7, *,+}+\infty$ and Gabriella Spengler ${ }^{1, *, \dagger}$
}

1 Department of Medical Microbiology and Immunobiology, Faculty of Medicine, University of Szeged, Dóm tér 10, 6720 Szeged, Hungary; mosolygo.timea@med.u-szeged.hu (T.M.);

kincses.annamaria@med.u-szeged.hu (A.K.); csonka.andrea83@gmail.com (A.C.); szabotadam@gmail.com (Á.S.T.)

2 Department of Obstetrics and Gynecology, Faculty of Medicine, University of Szeged, Semmelweis utca 1, 6725 Szeged, Hungary

3 Department of Technology and Biotechnology of Drugs, Jagiellonian University Medical College, Medyczna 9, 30-688 Kraków, Poland; karolina.witek@uj.edu.pl (K.W.); marcmalgorzata@gmail.com (M.A.M.); j.handzlik@uj.edu.pl (J.H.); mfkonono@cyf-kr.edu.pl (K.K.-K.) Department of Pharmaceutical Technology and Chemistry, School of Pharmacy and Nutrition, University of Navarra, Irunlarrea 1, 31008 Pamplona, Spain; sanmartin@unav.es

5 Instituto de Investigación Sanitaria de Navarra (IdiSNA), Irunlarrea 3, 31008 Pamplona, Spain

6 Interdisciplinary Excellence Centre, Department of Inorganic and Analytical Chemistry, University of Szeged, Dóm tér 7, 6720 Szeged, Hungary

7 Instituto de Química Orgánica General (IQOG-CSIC), Consejo Superior de Investigaciones Científicas, Juan de la Cierva 3, 28006 Madrid, Spain

* Correspondence: e.dominguez-alvarez@iqog.csic.es (E.D-Á.); spengler.gabriella@med.u-szeged.hu (G.S.); Tel.: +34-91-258-7661 (E.D.-Á.); +36-62-445-115 (G.S.)

+ These authors contributed equally to this work.

Academic Editor: Peter J. Rutledge

Received: 12 March 2019; Accepted: 13 April 2019; Published: 16 April 2019

\begin{abstract}
Bacterial multidrug resistance is becoming a growing problem for public health, due to the development and spreading of bacterial strains resistant to antimicrobials. In this study, the antibacterial and multidrug resistance reversing activity of a series of seleno-carbonyl compounds has been evaluated. The effects of eleven selenocompounds on bacterial growth were evaluated in Staphylococcus aureus, methicillin resistant S. aureus (MRSA), Enterococcus faecalis, Escherichia coli, and Chlamydia trachomatis $\mathrm{D}$. The combination effect of compounds with antibiotics was examined by the minimum inhibitory concentration reduction assay. Their efflux pump (EP) inhibitory properties were assessed using real-time fluorimetry. Relative expressions of EP and quorum-sensing genes were studied by quantitative PCR. Results showed that a methylketone selenoester had remarkable antibacterial activity against Gram-positive bacteria and potentiated the activity of oxacillin in MRSA. Most of the selenocompounds showed significant anti-chlamydial effects. The selenoanhydride and the diselenodiester were active inhibitors of the AcrAB-TolC system. Based on these results it can be concluded that this group of selenocompounds can be attractive potential antibacterials and EP inhibitors. The discovery of new derivatives with a significant antibacterial activity as novel selenocompounds, is of high impact in the fight against resistant pathogens.
\end{abstract}

Keywords: selenocompounds; selenoesters; AcrAB-TolC efflux pump; Chlamydia trachomatis D; Escherichia coli K-12 AG100; Staphylococcus aureus 


\section{Introduction}

Multidrug resistance is becoming a serious problem in the treatment of resistant bacterial infections. The discovery of novel antibacterial or multidrug resistance reversing agents is extremely urgent as soon we may lack effective drugs to treat bacterial infections caused by the arising superbugs resistant to the majority of the clinically available antibiotics [1]. Selenium (Se)-containing molecules could be possible alternatives in the development of a new approach to combat infections caused by multidrug resistant (MDR) pathogens. Se is an important element in biological molecules in archea, bacteria, and eukaryotes [2]. In humans, Se is an essential trace element and also has chemopreventive effects [3].

In this context, a few studies have reported that certain selenocompounds have shown an interesting antibacterial activity. First, a series of selenides-bearing benzenesulfonamide moieties has been found to strongly inhibit the carbonic anhydrases VchCA $\alpha$ and VchCA $\beta$ of Vibrio cholerae, thus, exerting an inhibition on the growth and pathogenicity of this bacterium [4]. In addition, a degraded selenide polysaccharide, extracted from Enteromorpha prolifera, has been found to show antibacterial activity against Escherichia coli [5]. Additionally, a series of fused selenazolinium salts have been shown to have a potent activity against ESKAPE pathogens, which are: vancomycin-resistant Enterococci, methicillin-resistant Staphylococcus aureus (MRSA), Klebsiella pneumoniae, Acinetobacter baumannii, Pseudomonas aeruginosa, and carbapenem-resistant Enterobacteriaceae. The majority of these compounds have minimum inhibitory concentration (MIC) values below $1 \mu \mathrm{g} / \mathrm{mL}$, in resistant bacterial strains of MRSA, K. pneumoniae, A. baumanii, and P. aeruginosa [6]. This last work highlights the potential applications of selenocompounds, in the treatment of infections caused by the MDR bacterial strains. Our previous studies have demonstrated that the selenoanhydride $\mathbf{1}$ and selected selenoesters 2-11 (Table 1) have shown potent anticancer activity against ATP-Binding cassette sub-family B member 1 (ABCB1)-overexpressing MDR mouse T-lymphoma cells and MDR colon adenocarcinoma cells [7,8]. The ABC family of protein transporters also plays an important role in bacterial multidrug resistance [9]. Several members of the ABC family, e.g., MsrA in staphylococci [10,11] or Msr(D) in Streptococcus pneumoniae [12], significantly contribute to the efflux of antibiotics, and are considered as attractive protein targets in experimental chemotherapy. A major factor of bacterial and cancer drug resistance is assigned to the MDR efflux transporter proteins, expelling toxic compounds and drugs out of the cells. Based on the energy source of these pumps, the primary transporter derives their energy from the hydrolysis of ATP (ABC-transporters) and secondary transporters use proton or ion gradients to drive the extrusion of toxic compounds. Using selenocompounds, such as chemosensitizers, these compounds have been shown to inhibit the ABCB1 in cancer cells [7,8], and based on these results, our aim was to investigate the efflux pump inhibitory properties of these selenocompounds on the representative bacterial efflux system AcrAB-TolC. RND (Resistance-Nodulation-Division) family transporters are widespread, especially among Gram-negative bacteria, and catalyse the efflux of antibiotics and biocides. This tripartite efflux system consists of an outer membrane channel and periplasmic adaptor proteins, and the inner membrane transporter AcrB [13]. The MarR transcription factor regulates resistance to diverse antibiotics, organic solvents and oxidative stress agents by controlling the expression of efflux pumps (including AcrAB-TolC) through the repression of the operon that encodes the transcriptional activator MarA. The antibiotic resistance arises when the MarR protein is inactivated or the expression of marR genes is inhibited [14]. Although the expression of AcrAB-TolC efflux pump is regulated at several levels, the MarR the AcrR also regulates it negatively, meanwhile, the MarA, SoxS, and Rob are activators of this efflux pump [15]. In addition, the quorum sensing (QS) regulators, such as SdiA could also affect the expression of AcrAB-TolC efflux pump in E. coli, since AcrAB-TolC has been proposed to pump out QS signals [16]. 
Table 1. Selenocompounds evaluated as antibacterial and as multidrug resistance reversing agents—selenoanhydride (1) and selenoesters (2-11).

\begin{tabular}{cccccc}
\hline & & & & & \\
\hline
\end{tabular}

Furthermore, coating surfaces with Se could reduce the bacterial attachment to prosthetic devices [17], whereas sodium selenite exhibited ulcer healing and antibacterial activity against Helicobacter pylori [18]. Various studies have highlighted the antimicrobial properties of elemental Se, in the form of nanoparticles (SeNP) against S. aureus [19-22], Staphylococcus epidermidis, K. pneumoniae, Bacillus subtilis [23], P. aeruginosa, E. coli, and A. baumannii [24]. Additionally, biogenic SeNPs, synthesized by different non-pathogenic bacterial strains and stabilized with bacterial proteins, have shown activity against pathogenic bacteria $[25,26]$.

In addition, there is an emerging evidence that Chlamydia trachomatis is developing resistance to antibiotics, as certain clinical isolates have shown single- or multidrug resistance $[27,28]$. Consequently, the development of new antibacterials and multidrug resistance reversing compounds is required to overcome this emerging problem. Although there are numerous studies that have investigated the antibacterial activity of Se-containing (in)organic compounds and SeNPs, according to our knowledge, no report has been described regarding anti-chlamydial activity of selenocompounds. Furthermore, the selenocompounds found as anticancer agents and cancer efflux pump inhibitors have not yet been tested on any bacterial strains.

Herein, we report the antibacterial effects of selenocompounds 1-11 on Gram-negative and Gram-positive bacteria, such as E. coli, C. trachomatis D, Enterococcus faecalis, and S. aureus (including methicillin resistant strain, MRSA).

\section{Results}

\subsection{Antibacterial Activity: Determination of the MIC}

The ketone-containing selenoesters 9-11 showed a potent antibacterial activity against the Gram-positive S. aureus ATCC 25923 and MRSA HEMSA 5. The methylketone selenoester 9 was the most active agent with noteworthy MIC values in the low micromolar range ( 3.12 and $3.91 \mu \mathrm{M})$. The tert-butylketone selenoesters $\mathbf{1 0}$ and $\mathbf{1 1}$ showed lower antibacterial activity than methylketone selenoester $\mathbf{9}$, but was still significant $(25$ and $50 \mu \mathrm{M})$. The selenoanhydride $\mathbf{1}$ and the remaining selenoesters 2-8 evaluated were inactive as their MIC were equal or above $100 \mu \mathrm{M}$. The selenoester 9 showed also significant antibacterial activity towards E. faecalis, but this Gram-positive strain was less 
sensitive to 9 than $S$. aureus and MRSA $(\mathrm{MIC}=12.5 \mu \mathrm{M})$, and also was not sensitive to the rest of the selenocompounds tested (MIC > $100 \mu \mathrm{M})$, (Table 2).

In contrast, none of the eleven Se derivatives demonstrated antibacterial effects against the two Gram-negative strains evaluated in this study, which are the AcrAB-TolC-expressing E. coli AG100 and the AcrAB-TolC-deleted mutant E. coli AG100A. In these two strains, all compounds showed MIC values above $100 \mu \mathrm{M}$ (data not shown).

Table 2. Minimum inhibitory concentration (MICs) of the selenocompounds on the Gram-positive bacteria. In bold-MIC values $<10 \mu \mathrm{M}$.

\begin{tabular}{cccc}
\hline \multirow{3}{*}{ Compounds } & \multicolumn{3}{c}{ MIC $(\mu \mathrm{M})$} \\
\cline { 2 - 4 } & $\begin{array}{c}\text { Staphylococcus aureus } \\
\text { ATCC 25923 }\end{array}$ & $\begin{array}{c}\text { Staphylococcus aureus } \\
\text { HEMSA 5 }\end{array}$ & $\begin{array}{c}\text { Enterococcus Faecalis } \\
\text { ATCC 29212 }\end{array}$ \\
\hline $\mathbf{1}$ & $>100$ & $>125$ & $>100$ \\
$\mathbf{2}$ & 100 & $>125$ & $>100$ \\
$\mathbf{3}$ & 100 & $>125$ & $>100$ \\
$\mathbf{4}$ & 100 & $>125$ & $>100$ \\
$\mathbf{5}$ & $>100$ & $>125$ & $>100$ \\
$\mathbf{6}$ & $>100$ & $>125$ & $>100$ \\
$\mathbf{7}$ & 100 & 125 & $>100$ \\
$\mathbf{8}$ & 100 & $>125$ & $>100$ \\
$\mathbf{9}$ & 3.12 & 3.91 & 12.5 \\
$\mathbf{1 0}$ & 25 & $>125$ & $>100$ \\
$\mathbf{1 1}$ & 50 & $>125$ & $>100$ \\
\hline
\end{tabular}

\subsection{Enhancement of the Activity of Antibiotics}

In order to determine if selenocompounds 1-11 enhance the activity of antibiotics, they were tested in combination with antibiotics commonly used in clinical therapy, which are substrates of the AcrB pump — tetracycline [29] and ciprofloxacin [30]. The combined effects of selenocompounds and these antibiotics were tested on the AcrAB-TolC expressing Gram-negative E. coli AG100 strain. In addition, the chemosensitizing effects of selenocompounds on the Gram-positive MRSA HEMSA 5 strain were studied in combination with oxacillin. These antibiotics have been selected among the ones that are more widely used in clinical practice, in an attempt to cover different mechanisms of action, to see which ones are more affected by the selenocompounds. Gram-negative efflux pumps of the RND superfamily in Gram-negative bacteria are crucial to the cellular defence mechanisms, but the overexpression of these pumps can lead to multidrug resistance, which is an alarming problem for health care. The AcrAB-TolC system containing the RND type pump AcrB has been studied extensively, due to its importance in bacterial resistance. As an in vitro model system we used the AcrAB-TolC overexpressing E. coli AG100 strain and its pump-deleted mutant strain E. coli AG100A, in order to find effective efflux pump inhibitor (EPI) compounds. EPIs as chemosenzitizers could reverse the resistant phenotype, and in combination with antibiotics, they could enhance the activity of these conventional antibiotics. Moreover, the Gram-positive methicillin resistant Staphylococcus aureus (MRSA) is a major concern in healthcare facilities, for this reason our aim was to test the selenocompounds on reference ATCC and resistant MRSA strains. The enhancement of the activity of oxacillin was studied as the ability of compounds 1-11, to reduce MIC of oxacillin against MRSA, whereas the enhancement of tetracycline or ciprofloxacin was studied analogously for AcrAB-TolC-expressing E. coli strain (Table 3).

In the absence of the selenocompounds, oxacillin showed MIC value of $374 \mu \mathrm{M}(150 \mu \mathrm{g} / \mathrm{mL})$ against MRSA, since this strain was highly resistant to this $\beta$-lactam antibiotic. The methylketone selenoester 9 , at a low concentration of $1.95 \mu \mathrm{M}(0.537 \mu \mathrm{g} / \mathrm{mL})$, exerted a noteworthy 64-fold reduction of the MIC value of oxacillin to $5.84 \mu \mathrm{M}(2.34 \mu \mathrm{g} / \mathrm{mL})$. Hence, this compound can be useful as a potent agent to reverse the resistance of MRSA to oxacillin. Interestingly, the rest of the compounds 1-8, 10, and 11 were not active, even at the concentration of $62.5 \mu \mathrm{M}$ (MIC reduction of oxacillin $\leq 2)$. 
However, none of the tested selenocompounds were able to improve the efficacy of antibiotics against the AcrAB-TolC-overexpressing strain of E. coli with the above-mentioned excellent 64-fold factor. The highest reductions observed in E. coli were a 2-fold reduction of the MIC values of tetracycline (compound 9 ) and of ciprofloxacin (compounds $9, \mathbf{1 0}$ ).

Table 3. Numerical value of the reduction of the MICs of selected antibiotics in methicillin resistant S. aureus (MRSA) or in E. coli AG100 exerted by selenocompounds when administered in combination with antibiotics.

\begin{tabular}{cccccc}
\hline & \multicolumn{2}{c}{ MRSA HEMSA 5 } & \multicolumn{3}{c}{ Escherichia coli AG100 } \\
\cline { 2 - 6 } Cpd $^{\mathbf{1}}$ & $\begin{array}{c}\text { Concentration of } \\
\text { Compound }[\mu \mathrm{M}]^{2}\end{array}$ & $\begin{array}{c}\text { Reduction of } \\
\text { Oxacillin MIC }\end{array}$ & $\begin{array}{c}\text { Concentration of } \\
\text { Compound }[\mu \mathrm{M}]\end{array}$ & $\begin{array}{c}\text { Reduction of } \\
\text { Tetracycline mic }\end{array}$ & $\begin{array}{c}\text { Reduction of } \\
\text { Ciprofloxacin mic }\end{array}$ \\
\hline $\mathbf{1}$ & 62.5 & no effect & 50 & no effect & no effect \\
$\mathbf{2}$ & ND & ND $^{3}$ & 50 & no effect & no effect \\
$\mathbf{3}$ & 62.5 & 2 -fold & 50 & no effect & no effect \\
$\mathbf{4}$ & 62.5 & no effect & 50 & no effect & no effect \\
$\mathbf{5}$ & 62.5 & no effect & 50 & no effect & no effect \\
$\mathbf{6}$ & 62.5 & no effect & 50 & no effect & no effect \\
$\mathbf{7}$ & 62.5 & $\geq 2$-fold & 50 & no effect & no effect \\
$\mathbf{8}$ & 62.5 & -fold & 50 & 2-fold & no effect \\
$\mathbf{9}$ & 1.95 & 64-fold & 25 & no effect & 2 -fold \\
$\mathbf{1 0}$ & 62.5 & no effect & 50 & no effect & no effect \\
$\mathbf{1 1}$ & 62.5 & no effect & 50 &
\end{tabular}

${ }^{1}$ Cpd: Compound. ${ }^{2}$ Starting concentration of tetracycline: $8.4 \mu \mathrm{M}$; ciprofloxacin: $1.4 \mu \mathrm{M}$; and oxacillin: $747 \mu \mathrm{M}$.

${ }^{3}$ ND: Not determined.

\subsection{Anti-Chlamydial Activity}

Before the assessment of the anti-chlamydial activity of the selenocompounds, a cytotoxicity assay was performed on HeLa cells to determine the ranges of concentrations at which the selenocompounds can be evaluated without showing direct toxic effects to HeLa cells. Selenocompounds 2, 3, 5, 7, and 9-11, significantly inhibited the formation of chlamydial inclusions at selected concentrations (Figure 1).
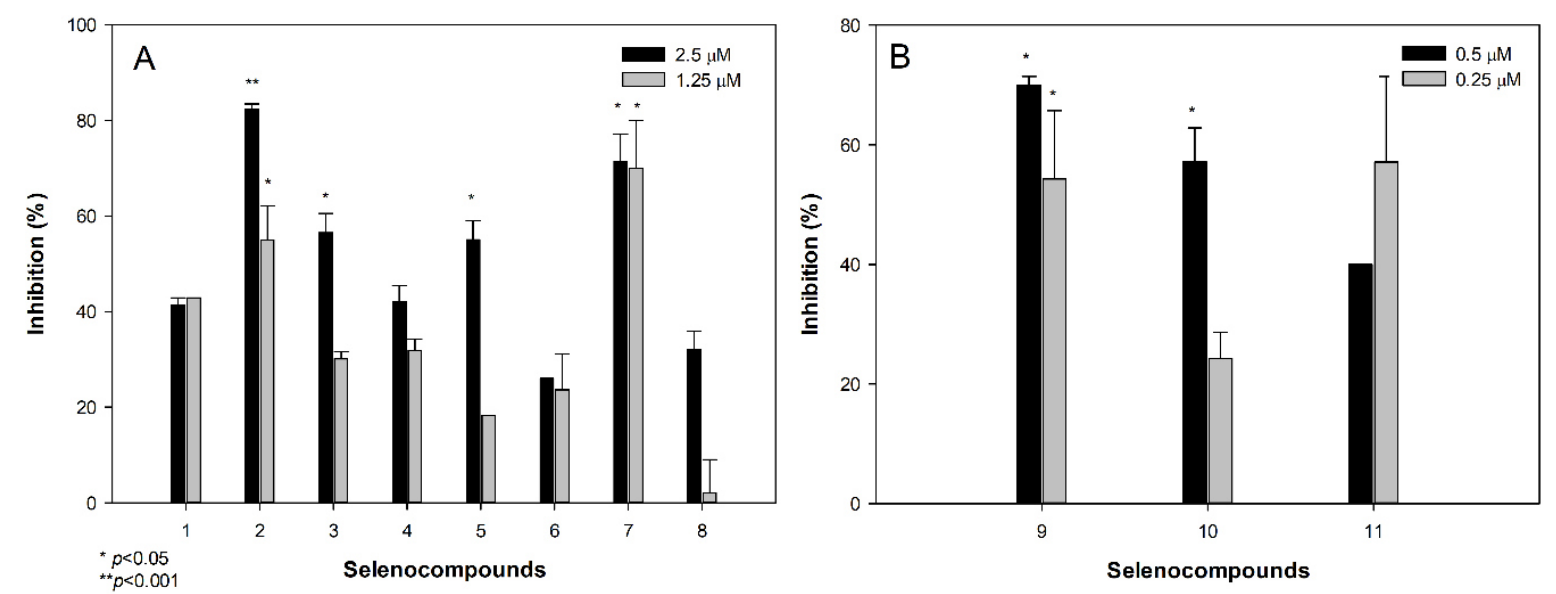

Figure 1. Anti-chlamydial effect of selenocompounds at 1.25 and $2.5 \mu \mathrm{M}(\mathbf{A})$, and at 0.25 and $0.5 \mu \mathrm{M}$ (B).

Compounds 2 and 7 at $2.5 \mu \mathrm{M}$, showed $82 \%$ and $71 \%$ inhibition, compared to the control, respectively. In addition, 2 and 7 were effective at $1.25 \mu \mathrm{M}$, whereas 9 and 10 inhibited the formation of inclusions at low submicromolar concentrations of $0.5 \mu \mathrm{M}$. The most potent anti-chlamydial selenocompounds were 9 and 11, as they inhibited more than $50 \%$ of the growth of $C$. trachomatis D, at a concentration of $0.25 \mu \mathrm{M}(0.0689$ and $0.0858 \mu \mathrm{g} / \mathrm{mL}$, respectively). 


\subsection{Real-Time Accumulation Assay}

Since ethidium bromide (EB) is a substrate of the AcrB efflux pump, the intracellular accumulation of EB provides information about the inhibition of the AcrAB-TolC system, in the presence of selenocompounds, in a time-dependent manner. The assay records the real-time accumulation of $\mathrm{EB}$, using a real-time thermocycler, by monitoring the fluorescence of EB inside the cells [31]. The activities of compounds 1-11 in the real-time EB accumulation assay, were given in terms of the relative fluorescence index (RFI) of the real-time accumulation curves (Table 4). In case of the real-time EB accumulation, the amount of EB accumulated by cells was higher if the difference between $R_{\text {treated }}$ and $\mathrm{RF}_{\text {untreated }}$ was greater, therefore, the degree of inhibition of the efflux pump system by the compound became greater. Compounds $\mathbf{9}$ and $\mathbf{1 0}$ possessed EPI activity and decreased the MIC of ciprofloxacin on E. coli AG100. However, the selenoanhydride 1 and the selenoester 4, compared with the positive control promethazine (PMZ, RFI: 0.15), strongly inhibited the efflux of AcrAB-TolC in E. coli AG100; they had no effect in combination with the antibiotics, suggesting that other cellular mechanisms might also be involved in the mode of action, such as interaction with cell wall components, formation of reactive oxygen species (ROS), or membrane destabilizing effects. Without investigating the possible metabolites of the selenocompounds, no further conclusions can be drawn, for this reason we are planning to study the metabolites of these compounds in future works. Derivatives $\mathbf{7}$ and $\mathbf{9 - 1 1}$ caused moderate inhibitory action, whereas 2, 3, 5, 6 and 8 showed weak or no activity on the intracellular EB accumulation in E. coli AG100. Among derivatives 7 and 9-11, compound 7, which contained a methyl oxoester in the alkyl moiety bound to Se, was the most active agent $(\mathrm{RFI}=0.13)$.

Table 4. Relative fluorescence index (RFI) for the effect of selenocompounds and positive control promethazine (PMZ) on the AcrAB-TolC-expressing Escherichia coli AG100 strain.

\begin{tabular}{|c|c|c|c|c|c|}
\hline \multirow{2}{*}{ Compound } & $\mathrm{RFI}^{\mathrm{a}}$ & \multirow{2}{*}{ Compound } & $\mathrm{RFI}^{\mathrm{a}}$ & \multirow{2}{*}{ Compound } & $\mathrm{RFI}^{\mathrm{a}}$ \\
\hline & Escherichia coli AG100 & & Escherichia coli AG100 & & Escherichia coli AG100 \\
\hline 1 & 0.28 & 5 & 0.04 & 9 & 0.11 \\
\hline 2 & 0.03 & 6 & 0.06 & 10 & 0.12 \\
\hline 3 & 0.04 & 7 & 0.13 & 11 & 0.11 \\
\hline 4 & 0.18 & 8 & 0.08 & PMZ & 0.15 \\
\hline
\end{tabular}

Nevertheless, no efflux pump inhibitory action of selenocompounds (1-11) was found in the E. coli AG100A strain.

\subsection{Gene Expression Analysis by Quantitative PCR}

For the effect of the selenocompounds on the relative expression of the efflux pump, antibiotic resistance and QS genes in E. coli AG100 - the most effective compounds in the EB real-time accumulation assay-were examined (compounds 1, 4, 7; Figure 2). In this assay, the genes of the multidrug efflux pump (AcrAB), the component of the E. coli mar locus (multiple antibiotic resistance), and the gene of SdiA were investigated. The changes in gene expression from reverse transcription quantitative PCR experiments were normalized to the expression of gapdh (internal control), in the same sample, and compared to the expression of the examined genes obtained from the untreated, control samples.

As shown in Figure 2A, compound 1 at $50 \mu \mathrm{M}$ concentration significantly up-regulated the $a c r B$, marR, and sdiA genes, after $4 \mathrm{~h}$ of exposure. However, after $18 \mathrm{~h}$, the expression of the $a c r B$ gene returned to the basal levels and the expression of the marR and sdiA genes, significantly increased. Compound 4 up-regulated the expression levels of $a c r B, \operatorname{mar} R$, and $s d i A$, after $4 \mathrm{~h}$, although after $18 \mathrm{~h}$, the expression levels of the $\operatorname{acr} B$ and $\operatorname{marR}$ genes decreased. The QS gene sdiA was significantly up-regulated after $18 \mathrm{~h}$ (Figure 2B).

Compound 7 also significantly up-regulated marR, after exposures of $4 \mathrm{~h}$ and of $18 \mathrm{~h}$. After $18 \mathrm{~h}$, the expression level of the RND transporters subunit genes $(a c r A, a c r B)$ was significantly increased (Figure 2C). 

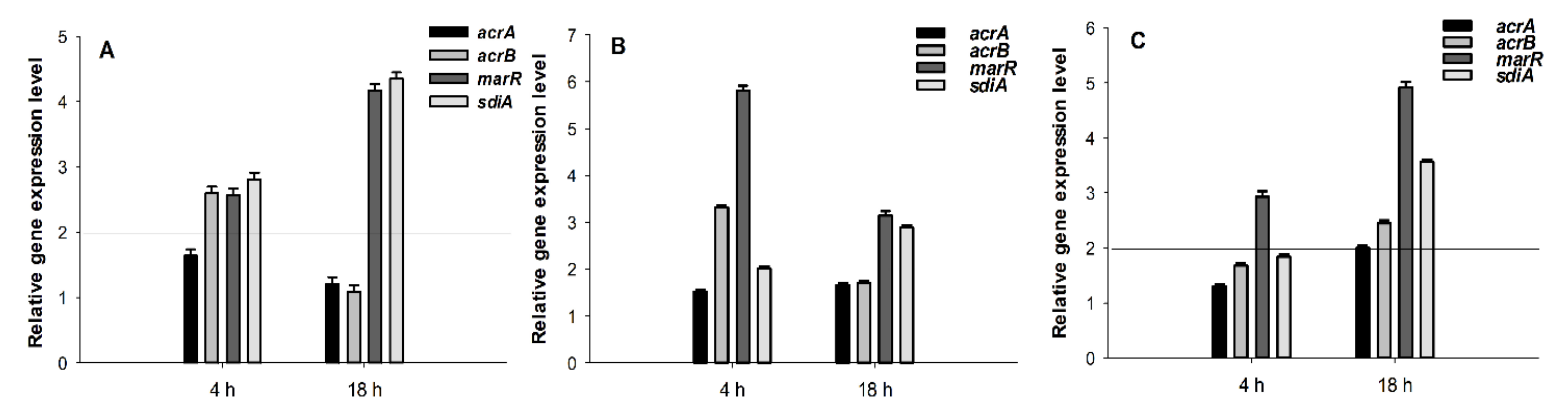

Figure 2. Relative gene expression levels of the genes of the $\operatorname{acr} A, \operatorname{acr} B, \operatorname{mar} R$, and $\operatorname{sdi} A$ in the presence of compounds 1 (A), 4 (B), and 7 (C), after 4 and $18 \mathrm{~h}$ exposure. The line denotes a threshold value, which was set at a two-fold increase in transcripts.

\section{Discussion}

Results of these studies indicate that selenoesters and selenoanhydrides, previously found as active anticancer or ABCB1 efflux pump inhibitors in cancer cells [7,8,32-35], also displayed a promising antimicrobial potential against the MDR bacterial strains.

\subsection{Antibacterial Activity}

The evaluation of the compounds proved that the ketone-containing selenoesters 9-11 showed an antibacterial activity against the Gram-positive reference S. aureus strain, whereas, the methylketone selenoester 9 was also active against the MRSA HEMSA 5 and E. faecalis. However, none of the compounds were active against the Gram-negative E. coli ag100. The background of the different antibacterial activity of $\mathbf{9}$ against the tested Gram-positives and Gram-negatives was unknown; further experiments are required to clarify whether the mechanism of action of the methylketone selenoester could be related with any kind of interaction between this compound and the bacterial cell wall that is typical for gram-positive bacteria. In contrast, the remaining alkyl groups $\left(-\mathrm{CH}_{3}\right)$ or alkyl-functionalized moieties $\left(-\mathrm{CH}_{2} \mathrm{CONH}_{2},-\mathrm{CH}_{2} \mathrm{COOCH}_{3}\right.$ and $-\mathrm{CH}_{2} \mathrm{COOPh}$, Table 1) bound to the Se atom rendered selenoesters that were ineffective against the tested strains. Interestingly, the compounds 9-11 were also the most potent anticancer agents in previous works [7,8,33], and they also showed a good selectivity towards cancer cells, with respect to non-tumour cell lines, as they showed selectivity indexes ranging from 8.4 to 14.4 [8].

In previous works, it was hypothesized that the possible mechanism of action of these compounds could be the hydrolysis of the compound and the subsequent liberation of the ionic species of Se, which could be responsible for the activity of the compounds [33]. In this case, this phenomenon enables us to hypothesize that the $\mathrm{CH}_{3} \mathrm{COCH}_{2} \mathrm{SeH}$, or its anionic form, are the chemical forms of Se that could be behind the observed activities. The lack of activity of the non-ketone selenoesters, directs a special attention to this $-\mathrm{SeCH}_{2} \mathrm{COCH}_{3}$ ketone-containing moiety.

\subsection{Enhancement of the Activity of Antibiotics}

The activity of 9 on the MDR clinical isolate (MRSA) was very promising, because compound 9 reduced the MIC of oxacillin in 64-fold (from $374 \mu \mathrm{M}$ to $5.84 \mu \mathrm{M}$ ). These results supported the potential applications of the methylketone selenoesters, such as antimicrobials, and the multidrug resistance reversing agents. These results were in accordance with the activity shown by these compounds as enhancers of the anticancer activity of chemotherapy drugs [35], suggesting that these selenium derivatives have the ability to effectively interact with the resistance mechanisms developed by the resistant bacterial strains and by the resistant cancer cells. This work intends to carry out a screening of the potential applications of the selenocompounds, and in future works we will attempt to ascertain the possible mechanisms of actions of the activities described herein, as this observed potential enhancement of the activity of oxacillin exerted by compound $\mathbf{9}$ in an MRSA clinical isolate. 


\subsection{Anti-Chlamydial Activity}

Previous studies have reported that selected selenocompounds, such as certain selenocyanates, selenoureas, and diselenides, showed antiproliferative activities against the intracellular forms of Leishmania spp. [36,37]. Taking those results into account, this study provided a new line of evidence for the action of selenoanhydride/selenoesters on an obligate intracellular chlamydial strain. In particular, different selenoesters, such as 2, 3, 5, 7, and 9-11, have exerted a noteworthy activity against C. trachomatis D. Furthermore, the activities of the methyl (9) and the tert-butyl (11) derivatives were very promising, as they inhibited the formation of more than $50 \%$ of the chlamydial inclusions, at a very low concentration $(0.25 \mu \mathrm{M})$. However, their mode of action has not been ascertained in this study.

Regarding the observed structure activity relationships of the anti-chlamydial assays, the ketone selenoesters 9-11 showed noteworthy activity at lower concentrations $(0.25 \mu \mathrm{M}, 0.5 \mu \mathrm{M})$, compared to the rest of the series $(1.25 \mu \mathrm{M}, 2.5 \mu \mathrm{M})$. Among the remaining selenoesters, the symmetric dimethyl selenodiester, which contains a thiophene ring 2 , and the methyl oxoester derivative 7 showed a better activity, and the activities of the symmetric dimethyl selenodiesters 3 and $\mathbf{5}$ were also remarkable. These fact highlights the importance of the symmetry for the activity against intracellular pathogens [36].

\subsection{Interaction of the Compounds with Bacterial Efflux Pumps}

The resistance to the current antibacterial drugs is one of the major therapeutic challenges in the treatment of bacterial infections, and knowing the potential of these derivatives as multidrug resistance reversing agents (proved both by the capacity to enhance the activity of antibiotics described above and by the enhancement of anticancer drugs reported in previous works), we have studied here the procedure through which selenocompounds interact with the bacterial AcrAB-TolC system in the E. coli AG100 strain.

The results obtained revealed that the cyclic selenoanhydride 1 significantly inhibited this bacterial AcrAB-TolC efflux pump in the E. coli AG100 strain. Similarly, EP inhibiting activity has been found for compounds 4 and 7 . The second most potent inhibitor was the symmetrical benzene derivative 1,3-disubstituted with methylselenoester moieties (4). Interestingly, its 1,4-disubstituted analogue (5) showed an EP-inhibitory activity, 4.5-fold lower, suggesting the importance of the substituents' topology for the expected biological effect. Taking into account the distinct difference in electron density properties between $m$ - and $p$-substituted phenyl rings, this factor seems to have affected the mechanisms of EP inhibition.

The well-characterized RND-type transporter, AcrB is associated with TolC and AcrA and is the major efflux pump of E. coli [38]. These efflux pumps recognize and extrude a large variety of antibiotics from the cytoplasm. The energy required for the operation of the efflux pump is provided by the proton motive force, created by the proton gradient resulting from electron transport [39]. This fact suggests that those selenocompounds, which possessed EP inhibitor activity, might interfere with the proton motive force. Surprisingly, compounds $\mathbf{1}$ and $\mathbf{4}$, which inhibited the AcrAB-TolC system, influenced the expression of the gene $a c r B$, which is a constituent of the AcrAB-TolC system. In addition, the compounds increased the expression of the QS gene sdiA, after $18 \mathrm{~h}$ of exposure, which suggests their roles in QS, although their QS inhibitory activities were not investigated in this study.

\section{Materials and Methods}

\subsection{Chemistry}

Eleven pure selenocompounds obtained as described earlier [33], were examined (1-11, Table 1). All compounds were stable in air and their purity was assessed by elemental analysis and ${ }^{1} \mathrm{H}$ and ${ }^{13} \mathrm{C}$ NMR, as reported in a previous work [35]. Before their use in biological assays, they were dissolved in dimethyl sulfoxide (DMSO; Merck KGaA, Darmstadt, Germany), to obtain stock solutions. Working solutions were prepared by dilutions in the culture medium. 


\subsection{Bacterial Strains}

Wild-type E. coli K-12 AG100 strain [argE3 thi-1 rpsL xyl mtl $\Delta$ (gal-uvrB) supE44] and its AcrAB-TolC-deleted mutant strain E. coli AG100A (a kind gift from Hiroshi Nikaido, Department of Molecular and Cell Biology and Chemistry, University of California, Berkeley, USA) were used for the evaluation of the EPI activity of the tested selenocompounds.

S. aureus ATCC 25923 and E. faecalis ATCC 29212 strains were used to determine the MIC. A methicillin-resistant $S$. aureus strain (MRSA HEMSA 5, a clinical isolate) was used in the combination assay, with oxacillin, to determine the capacity of compounds to enhance the antibacterial effect of this antibiotic. C. trachomatis reference strain (serovar D, UW-3/Cx, ATCC, VR-885D) was used in the anti-chlamydial assay.

\subsection{Propagation of C. trachomatis $D$}

C. trachomatis D was propagated on the HeLa 229 cells (ATCC, CCL-2.1), as described earlier [40]. The titre of the infectious elementary bodies was determined by an indirect immunofluorescence assay. Serial dilutions of the elementary bodies' preparation were inoculated onto the HeLa monolayers and, after a 48-h culture, the cells were fixed with acetone, and stained with monoclonal anti-Chlamydia LPS antibody (AbD Serotec, Oxford, UK) and FITC-labelled anti-mouse IgG (Merck KGaA, Darmstadt, Germany). The inclusions of $C$. trachomatis D were enumerated under a UV microscope.

\subsection{Determination of MIC}

The effects exerted by different concentrations of the compounds on the bacterial growth in S. aureus, E. faecalis, and E. coli AG100 were tested in 96-well plates. The MICs of selenocompounds were determined, according to the Clinical and Laboratory Standard Institute (CLSI) guidelines [41]. The DMSO exerted no antibacterial effect. Alternatively, the MIC of the oxacillin in MRSA HEMSA 5 was determined by the broth microdilution method, in a cation-adjusted Mueller-Hinton Broth (MHB II), according to the recommendations of the CLSI. Results were recorded after a 20- or 24-hour incubation at $37^{\circ} \mathrm{C}$.

\subsection{Enhancement of the Activity of Antibiotics}

The chemosensitizing effect of the tested selenocompounds was evaluated through the determination of the MIC values of the antibiotics, in the presence of sub-inhibitory concentrations of the compounds (MIC/2 or MIC/4), in both Gram-negative (E. coli AG100) and Gram-positive (MRSA) strains. The MICs were evaluated in the E. coli strain, by a two-fold broth microdilution method in the 96-well plates, using serial dilutions of tetracycline (from 8.4 to $0.16 \mu \mathrm{M}$ ) and ciprofloxacin (from 1.4 to $\left.2.7 \times 10^{-3} \mu \mathrm{M}\right)$. The first four rows contained two-fold dilutions of antibiotics, and the combinations of the antibiotics and tested compounds were added into the last four rows. $10^{-4}$ dilution of an overnight bacterial culture in $50 \mu \mathrm{L}$ of MHB was then added to each well, with the exception of the medium control wells. The plates were then incubated at $37^{\circ} \mathrm{C}$ for $18 \mathrm{~h}$. MIC values of the antibiotics and their combination with the tested compounds were determined by naked eyes. In the assay with oxacillin in the MRSA HEMSA 5 bacterial strain, a microdilution method in MHB II was used.

\subsection{Anti-Chlamydial Assay}

Elementary bodies of $C$. trachomatis $\mathrm{D}\left(4 \times 10^{3} \mathrm{IFU} / \mathrm{mL}\right)$ were incubated with compounds at selected concentrations $(0.25,0.5,1.25,2.5 \mu \mathrm{M})$ in sucrose-phosphate-glutamic acid buffer (SPG) for $2 \mathrm{~h}$ at $37^{\circ} \mathrm{C}$. As a control, C. trachomatis D was also incubated alone in the SPG. To quantify the anti-chlamydial effects of the compounds, HeLa cells were seeded in 24-well plates with 13-mm cover glasses. The confluent cells were infected with compound-treated C. trachomatis D or with the non-treated controls. After $48 \mathrm{~h}$, the cells were fixed with acetone at $-20^{\circ} \mathrm{C}$ for $10 \mathrm{~min}$. The titre of the infectious elementary bodies was determined by the indirect immunofluorescence assay, as described earlier [42]. 


\subsection{Real-Time Accumulation Assay}

The effect of the studied selenocompounds on the real-time accumulation of ethidium bromide (EB) was assessed by an automated EB method [43], using a LightCycler real-time thermocycler (LightCycler 1.5; Roche). The compounds were added individually at different concentrations at MIC/2 to the EB solution in PBS. The final concentration of EB was 1 and $0.25 \mu \mathrm{g} / \mathrm{mL}$ for E. coli AG100 and AG100A, respectively. The method for the calculation of the relative fluorescence index (RFI) of the last time point (minute 30) was described earlier by Kincses et al. [44]. Promethazine (PMZ; EGIS) was applied as a positive control.

\subsection{Expression Analyses of Genes by Quantitative PCR}

Total RNA was isolated from E. coli AG100 (OD of 0.6 at $600 \mathrm{~nm}$ ) using the NucleoSpin RNA kit (Macherey Nagel) according to the manufacturer's instructions. The concentration of the extracted RNA templates was assessed by spectrophotometry at $260 \mathrm{~nm}$.

The expression of the $a c r A$, the $a c r B$, the multiple antibiotic resistance protein $\mathrm{R}(\operatorname{mar} R)$, and the quorum-sensing transcriptional activator ( $s d i A)$ genes was studied by reverse transcription quantitative PCR (RT-qPCR), as described earlier [44]. The real-time one-step PCR was performed in a CFX96 Touch real-time PCR detection system (Bio-Rad), strictly adhering to the manufacturer recommendations of the SensiFAST ${ }^{\text {тм }}$ SYBR No-ROX One-Step Kit (Bioline GmbH, Luckenwalde, Germany). The forward and reverse primers used in the experiment are shown in Table 5 [44,45]. The cycle threshold $(\mathrm{Ct})$ values were determined with the Bio-Rad CFX Manager Software version 3.1. Relative quantification analysis was carried out using the Livak method [46]. The expression of gapdh was used as the internal control and the untreated E. coli AG 100 served as the external control. We have defined a threshold value-increases greater than 2 -fold in the amount of transcripts relative to the control samples were considered significant.

Table 5. Primers used in the RT-qPCR.

\begin{tabular}{|c|c|c|c|c|}
\hline Gene & Full Name & Primer Sequence $\left(5^{\prime}-3^{\prime}\right)$ & $\begin{array}{l}\text { Amplicon } \\
\text { size (bp) }\end{array}$ & Ref. \\
\hline $\operatorname{acr} A$ & Acridine resistance protein A & $\begin{array}{l}\text { CTTAGCCCTAACAGGATGTG } \\
\text { TTGAAATTACGCTTCAGGAT }\end{array}$ & 189 & [45] \\
\hline$a c r B$ & Acridine resistance protein $B$ & $\begin{array}{c}\text { CGTACACAGAAAGTGCTCAA } \\
\text { CGCTTCAACTTTGTTTTCTT }\end{array}$ & 183 & [45] \\
\hline $\operatorname{mar} R$ & $\begin{array}{c}\text { Multiple antibiotic resistance } \\
\text { protein } R\end{array}$ & $\begin{array}{l}\text { AGCGATCTGTTCAATGAAAT } \\
\text { TTCAGTTCAACCGGAGTAAT }\end{array}$ & 170 & {$[45]$} \\
\hline sdiA & $\begin{array}{l}\text { Quorum-sensing } \\
\text { transcriptional activator }\end{array}$ & $\begin{array}{l}\text { CTGATGGCTCTGATGCGTTTA } \\
\text { TCTGGTGGAAATTGACCGTATT }\end{array}$ & 163 & {$[44]$} \\
\hline gapdh & $\begin{array}{c}\text { Glyceraldehyde-3-phospate } \\
\text { dehydrogenase }\end{array}$ & $\begin{array}{l}\text { ACTTACGAGCAGATCAAAGC } \\
\text { AGTTTCACGAAGTTGTCGTT }\end{array}$ & 170 & [45] \\
\hline
\end{tabular}

\section{Conclusions}

Herein, we have reported the evaluation of the antibacterial and multidrug resistance reversing activity of 11 novel selenocompounds. The most active compound in the antibacterial assay, the methylketone selenoester 9, showed potential antibacterial activity against the different strains of S. aureus, E. faecalis, and C. trachomatis D, even at very low concentrations $(0.25 \mu \mathrm{M}$ for $C$. trachomatis D). This selenocompound also enhanced the efficacy of antibiotics, namely it multiplied by 64-fold the antibacterial action of oxacillin, against the MDR clinical isolate of S. aureus. Alternatively, three compounds (the selenoanhydride 1 and the selenoesters 4 and 7) inhibited the tripartite multidrug resistance efflux pump AcrAB-TolC in E. coli, and affected the expression of the different genes related to these resistance processes. 
Based on these results, it can be concluded that this group of selenocompounds can be attractive potential EP inhibitors and antibacterial lead scaffolds, for further development of new chemical tools, to overcome bacterial multidrug resistance.

Author Contributions: E.D.-Á. and C.S. synthesized the compounds evaluated. T.M., G.S., J.H. and K.K.-K. conceived the experiments; T.M., A.K., A.C., Á.S.T., K.W., M.A.M. and G.S. performed the biological experiments; T.M., G.S. and E.D.-Á. wrote the paper; T.M., C.S., J.H., K.K.K., G.S. and E.D.-Á. revised the manuscript; T.M. and G.S. provided the funding for the biological evaluation; and E.D.-Á and M.A.M. provided the funding of the article publication.

Funding: G.S. was supported by the János Bolyai Research Scholarship of the Hungarian Academy of Sciences, by the GINOP-2.3.2-15-2016-00038 project and by the University of Szeged, through the project SZTE ÁOK-KKA 2018/270-62-2. A.K. was supported by the ÚNKP-17-3 New National Excellence Program of the Ministry of Human Capacities of Hungary. E.D.A. was supported by the Spanish "Consejo Superior de Investigaciones Científicas" (CSIC, Spanish National Research Council), through Project 2017801027.

Conflicts of Interest: The authors declare no conflict of interest.

\section{References}

1. Drusano, G.L.; Louie, A.; MacGowan, A.; Hope, W. Suppression of Emergence of Resistance in Pathogenic Bacteria: Keeping Our Powder Dry, Part 1. Antimicrob. Agents Chemother. 2015, 60, 1183-1193. [CrossRef]

2. Lobanov, A.V.; Hatfield, D.L.; Gladyshev, V.N. Eukaryotic selenoproteins and selenoproteomes. Biochim. Biophys. Acta 2009, 1790, 1424-1428. [CrossRef]

3. Tinggi, U. Selenium: Its role as antioxidant in human health. Environ. Health Prev. Med. 2008, 13, 102-108. [CrossRef]

4. Angeli, A.; Abbas, G.; del Prete, S.; Capasso, C.; Supuran, C.T. Selenides bearing benzenesulfonamide show potent inhibition activity against carbonic anhydrases from pathogenic bacteria Vibrio cholerae and Burkholderia pseudomallei. Bioorg. Chem. 2018, 79, 319-322. [CrossRef] [PubMed]

5. Lü, H.; Gao, Y.; Shan, H.; Lin, Y. Preparation and antibacterial activity studies of degraded polysaccharide selenide from Enteromorpha prolifera. Carbohyd. Polym. 2014, 107, 98-102. [CrossRef]

6. Witek, K.; Nasim, M.; Bischoff, M.; Gaupp, R.; Arsenyan, P.; Vasiljeva, J.; Marć, M.; Olejarz, A.; Latacz, G.; Kieć-Kononowicz, K.; et al. Selenazolinium Salts as "Small Molecule Catalysts" with High Potency against ESKAPE Bacterial Pathogens. Molecules 2017, 22, 2174. [CrossRef]

7. Domínguez-Álvarez, E.; Gajdács, M.; Spengler, G.; Palop, J.A.; Marć, M.A.; Kieć-Kononowicz, K.; Amaral, L.; Molnár, J.; Jacob, C.; Handzlik, J.; et al. Identification of selenocompounds with promising properties to reverse cancer multidrug resistance. Bioorg. Med. Chem. Lett. 2016, 26, 2821-2824. [CrossRef] [PubMed]

8. Gajdács, M.; Spengler, G.; Sanmartín, C.; Marć, M.A.; Handzlik, J.; Domínguez-Álvarez, E. Selenoesters and selenoanhydrides as novel multidrug resistance reversing agents: A confirmation study in a colon cancer MDR cell line. Bioorg. Med. Chem. Lett. 2017, 27, 797-802. [CrossRef]

9. Handzlik, J.; Matys, A.; Kieć-Kononowicz, K. Recent Advances in Multi-Drug Resistance (MDR) Efflux Pump Inhibitors of Gram-Positive Bacteria S. aureus. Antibiotics 2013, 2, 28-45. [CrossRef] [PubMed]

10. Pozzi, G.; Iannelli, F.; Oggioni, M.R.; Santagati, M.; Stefani, S. Genetic elements carrying macrolide efflux genes in streptococci. Curr. Drug Targets Infect. Disord. 2004, 4, 203-206. [CrossRef]

11. Reynolds, E.; Ross, J.I.; Cove, J.H. Msr(A) and related macrolide/streptogramin resistance determinants: Incomplete transporters? Int. J. Antimicrob. Agents 2003, 22, 228-236. [CrossRef]

12. Robertson, G.T.; Doyle, T.B.; Lynch, A.S. Use of an efflux-deficient streptococcus pneumoniae strain panel to identify ABC-class multidrug transporters involved in intrinsic resistance to antimicrobial agents. Antimicrob. Agents Chemother. 2005, 49, 4781-4783. [CrossRef]

13. Daury, L.; Orange, F.; Taveau, J.-C.; Verchère, A.; Monlezun, L.; Gounou, C.; Marreddy, R.K.R.; Picard, M.; Broutin, I.; Pos, K.M.; et al. Tripartite assembly of RND multidrug efflux pumps. Nat. Commun. 2016, 7, 10731. [CrossRef]

14. Gupta, A.; Pande, A.; Sabrin, A.; Thapa, S.S.; Gioe, B.W.; Grove, A. MarR Family Transcription Factors from Burkholderia Species: Hidden Clues to Control of Virulence-Associated Genes. Microbiol. Mol. Biol. Rev. 2018, 83, e00039-18. [CrossRef] 
15. Grkovic, S.; Brown, M.H.; Skurray, R.A. Regulation of bacterial drug export systems. Microbiol. Mol. Biol. Rev. 2002, 66, 671-701. [CrossRef] [PubMed]

16. Tavío, M.M.; Aquili, V.D.; Poveda, J.B.; Antunes, N.T.; Sánchez-Céspedes, J.; Vila, J. Quorum-sensing regulator sdiA and marA overexpression is involved in in vitro-selected multidrug resistance of Escherichia coli. J. Antimicrob. Chemother. 2010, 65, 1178-1186. [CrossRef] [PubMed]

17. Holinka, J.; Pilz, M.; Kubista, B.; Presterl, E.; Windhager, R. Effects of selenium coating of orthopaedic implant surfaces on bacterial adherence and osteoblastic cell growth. Bone Joint J. 2013, 95, 678-682. [CrossRef] [PubMed]

18. Kumar, B.S.; Tiwari, S.K.; Manoj, G.; Kunwar, A.; Amrita, N.; Sivaram, G.; Abid, Z.; Ahmad, A.; Khan, A.A.; Priyadarsini, K.I. Anti-unlcer and antimicrobial activities of sodium selenite against Helicobacter pylori: In vitro and in vivo evaluation. Scand. J. Infect. Dis. 2010, 42, 266-274. [CrossRef] [PubMed]

19. Aribi, M.; Meziane, W.; Habi, S.; Boulatika, Y.; Marchandin, H.; Aymeric, J.-L. Macrophage Bactericidal Activities against Staphylococcus aureus Are Enhanced In Vivo by Selenium Supplementation in a Dose-Dependent Manner. PLoS ONE 2015, 10, e0135515. [CrossRef] [PubMed]

20. Wadhwani, S.A.; Shedbalkar, U.U.; Singh, R.; Chopade, B.A. Biogenic selenium nanoparticles: Current status and future prospects. Appl. Microbiol. Biotechnol. 2016, 100, 2555-2566. [CrossRef]

21. Cihalova, K.; Chudobova, D.; Michalek, P.; Moulick, A.; Guran, R.; Kopel, P.; Adam, V.; Kizek, R. Staphylococcus aureus and MRSA Growth and Biofilm Formation after Treatment with Antibiotics and SeNPs. Int. J. Mol. Sci. 2015, 16, 24656-24672. [CrossRef]

22. Chudobova, D.; Cihalova, K.; Dostalova, S.; Ruttkay-Nedecky, B.; Rodrigo, M.A.M.; Tmejova, K.; Kopel, P.; Nejdl, L.; Kudr, J.; Gumulec, J.; et al. Comparison of the effects of silver phosphate and selenium nanoparticles on Staphylococcus aureus growth reveals potential for selenium particles to prevent infection. FEMS Microbiol. Lett. 2014, 351, 195-201. [CrossRef]

23. Stevanović, M.; Filipović, N.; Djurdjević, J.; Lukić, M.; Milenković, M.; Boccaccini, A. 45S5Bioglass@-based scaffolds coated with selenium nanoparticles or with poly(lactide-co-glycolide)/selenium particles: Processing, evaluation and antibacterial activity. Colloid. Surf. B 2015, 132, 208-215. [CrossRef]

24. Huang, X.; Chen, X.; Chen, Q.; Yu, Q.; Sun, D.; Liu, J. Investigation of functional selenium nanoparticles as potent antimicrobial agents against superbugs. Acta Biomater. 2016, 30, 397-407. [CrossRef]

25. Sonkusre, P.; Singh Cameotra, S. Biogenic selenium nanoparticles inhibit Staphylococcus aureus adherence on different surfaces. Colloid. Surf. B 2015, 136, 1051-1057. [CrossRef] [PubMed]

26. Srivastava, N.; Mukhopadhyay, M. Green synthesis and structural characterization of selenium nanoparticles and assessment of their antimicrobial property. Bioproc. Biosyst. Eng. 2015, 38, 1723-1730. [CrossRef] [PubMed]

27. Sandoz, K.M.; Rockey, D.D. Antibiotic resistance in Chlamydiae. Future Microbiol. 2010, 5, 1427-1442. [CrossRef] [PubMed]

28. Mestrovic, T.; Ljubin-Sternak, S. Molecular mechanisms of Chlamydia trachomatis resistance to antimicrobial drugs. Front Biosci. 2018, 23, 656-670. [CrossRef]

29. Elkins, C.A.; Nikaido, H. Substrate specificity of the RND-type multidrug efflux pumps AcrB and AcrD of Escherichia coli is determined predominantly by two large periplasmic loops. J. Bacteriol. 2002, 184, 6490-6498. [CrossRef] [PubMed]

30. Ricci, V.; Piddock, L.J.V. Only for substrate antibiotics are a functional AcrAB-TolC efflux pump and RamA required to select multidrug-resistant Salmonella Typhimurium. J. Antimicrob. Chemother. 2009, 64, 654-657. [CrossRef] [PubMed]

31. Paixão, L.; Rodrigues, L.; Couto, I.; Martins, M.; Fernandes, P.; de Carvalho, C.C.C.R.; Monteiro, G.A.; Sansonetty, F.; Amaral, L.; Viveiros, M. Fluorometric determination of ethidium bromide efflux kinetics in Escherichia coli. J. Biol. Eng. 2009, 3, 18. [CrossRef]

32. Sanmartín, C.; Plano, D.; Domínguez, E.; Font, M.; Calvo, A.; Prior, C.; Encío, I.; Palop, J.A. Synthesis and pharmacological screening of several aroyl and heteroaroyl selenylacetic acid derivatives as cytotoxic and antiproliferative agents. Molecules 2009, 14, 3313-3338. [CrossRef]

33. Domínguez-Álvarez, E.; Plano, D.; Font, M.; Calvo, A.; Prior, C.; Jacob, C.; Palop, J.A.; Sanmartín, C. Synthesis and antiproliferative activity of novel selenoester derivatives. Eur. J. Med. Chem. 2014, 73, 153-166. [CrossRef] 
34. Díaz-Argelich, N.; Encío, I.; Plano, D.; Fernandes, A.P.; Palop, J.A.; Sanmartín, C. Novel Methylselenoesters as Antiproliferative Agents. Molecules 2017, 22, 1288. [CrossRef]

35. Spengler, G.; Gajdács, M.; Marć, M.; Domínguez-Álvarez, E.; Sanmartín, C. Organoselenium Compounds as Novel Adjuvants of Chemotherapy Drugs-A Promising Approach to Fight Cancer Drug Resistance. Molecules 2019, 24, 336. [CrossRef]

36. Fernández-Rubio, C.; Campbell, D.; Vacas, A.; Ibañez, E.; Moreno, E.; Espuelas, S.; Calvo, A.; Palop, J.A.; Plano, D.; Sanmartin, C.; et al. Leishmanicidal Activities of Novel Methylseleno-Imidocarbamates. Antimicrob. Agents Chemother. 2015, 59, 5705-5713. [CrossRef]

37. Martín-Montes, Á.; Plano, D.; Martín-Escolano, R.; Alcolea, V.; Díaz, M.; Pérez-Silanes, S.; Espuelas, S.; Moreno, E.; Marín, C.; Gutiérrez-Sánchez, R.; et al. Library of Seleno-Compounds as Novel Agents against Leishmania Species. Antimicrobial. Agents Chemother. 2017, 61, e02546-16. [CrossRef]

38. Li, X.-Z.; Plésiat, P.; Nikaido, H. The challenge of efflux-mediated antibiotic resistance in Gram-negative bacteria. Clin. Microbiol. Rev. 2015, 28, 337-418. [CrossRef]

39. Nikaido, H.; Pagès, J.-M. Broad-specificity efflux pumps and their role in multidrug resistance of Gram-negative bacteria. FEMS Microbiol. Rev. 2012, 36, 340-363. [CrossRef]

40. Bogdanov, A.; Endrész, V.; Urbán, S.; Lantos, I.; Deák, J.; Burián, K.; Önder, K.; Ayaydin, F.; Balázs, P.; Virok, D.P. Application of DNA chip scanning technology for automatic detection of Chlamydia trachomatis and Chlamydia pneumoniae inclusions. Antimicrob. Agents Chemother. 2014, 58, 405-413. [CrossRef]

41. Clinical \& Laboratory Standards Institute: CLSI Guidelines. Available online: https://clsi.org/ (accessed on 24 July 2017).

42. Balogh, E.P.; Faludi, I.; Virók, D.P.; Endrész, V.; Burián, K. Chlamydophila pneumoniae induces production of the defensin-like MIG/CXCL9, which has in vitro antichlamydial activity. Int. J. Med. Microbiol. 2011, 301, 252-259. [CrossRef]

43. Viveiros, M.; Martins, A.; Paixão, L.; Rodrigues, L.; Martins, M.; Couto, I.; Fähnrich, E.; Kern, W.V.; Amaral, L. Demonstration of intrinsic efflux activity of Escherichia coli K-12 AG100 by an automated ethidium bromide method. Int. J. Antimicrob. Agents 2008, 31, 458-462. [CrossRef]

44. Kincses, A.; Szabó, Á.M.; Saijo, R.; Watanabe, G.; Kawase, M.; Molnár, J.; Spengler, G. Fluorinated Beta-diketo Phosphorus Ylides Are Novel Efflux Pump Inhibitors in Bacteria. In Vivo 2016, 30, 813-817. [CrossRef]

45. Viveiros, M.; Dupont, M.; Rodrigues, L.; Couto, I.; Davin-Regli, A.; Martins, M.; Pagès, J.-M.; Amaral, L. Antibiotic stress, genetic response and altered permeability of E. coli. PLoS ONE 2007, 2, e365. [CrossRef]

46. Livak, K.J.; Schmittgen, T.D. Analysis of Relative Gene Expression Data Using Real-Time Quantitative PCR and the 2- $\Delta \Delta$ CT Method. Methods 2001, 25, 402-408. [CrossRef]

Sample Availability: Not available.

(C) 2019 by the authors. Licensee MDPI, Basel, Switzerland. This article is an open access article distributed under the terms and conditions of the Creative Commons Attribution (CC BY) license (http://creativecommons.org/licenses/by/4.0/). 
IV. 

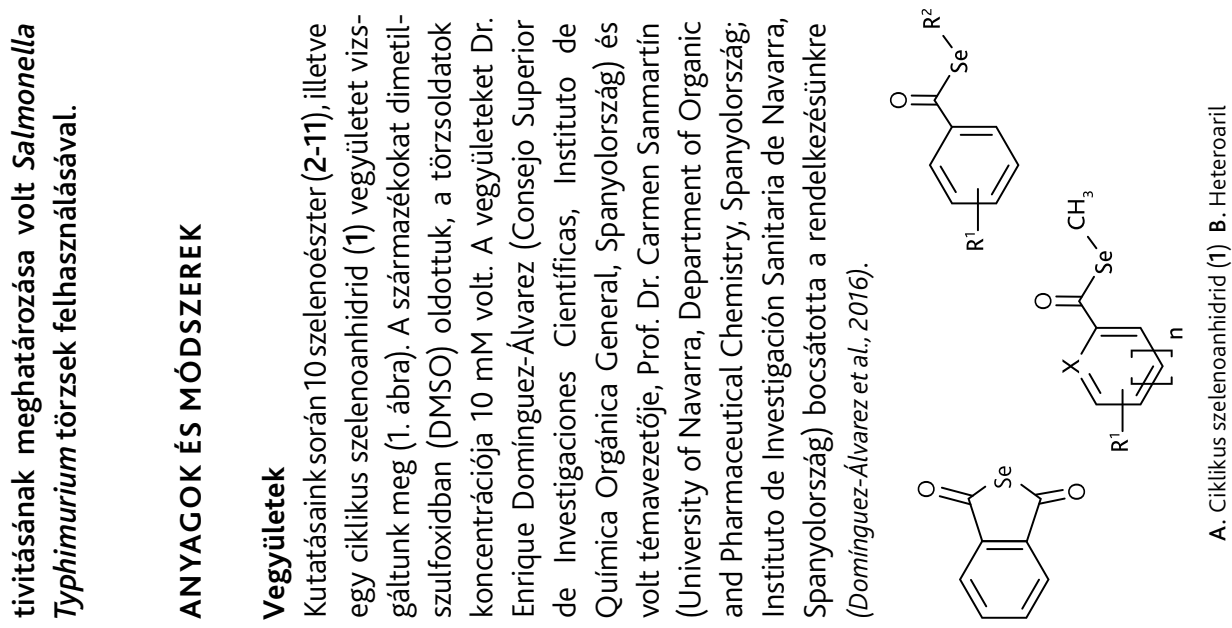

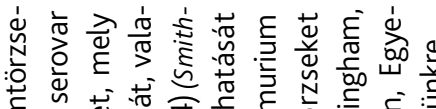

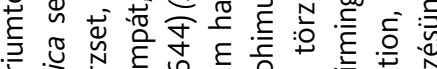

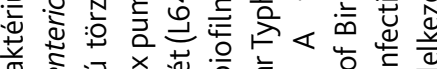

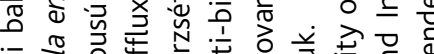

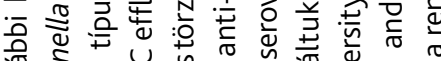

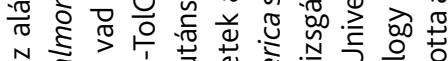

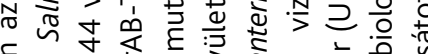

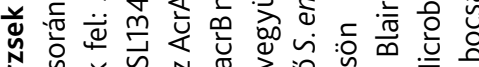

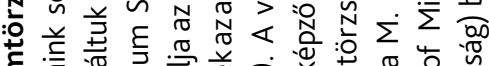
है

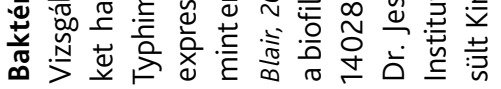

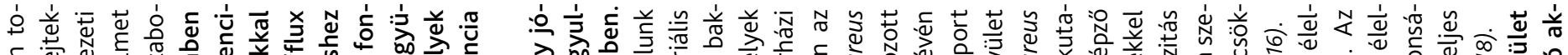

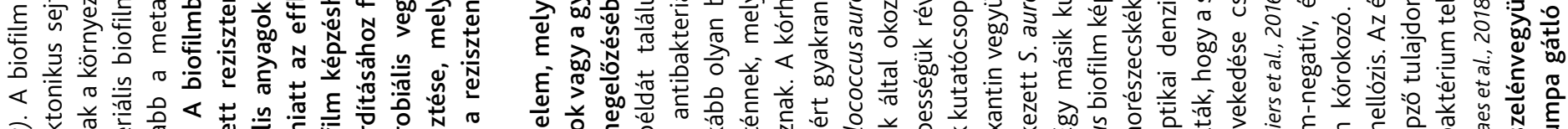

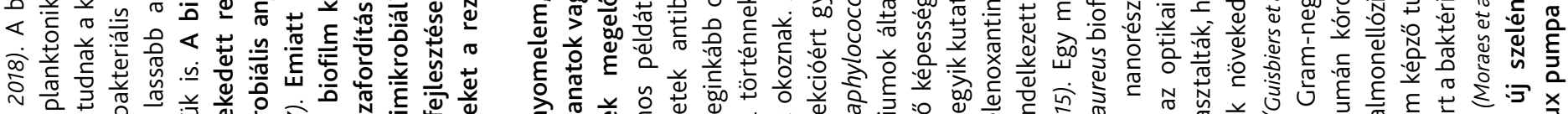
$\begin{array}{llll} & \\ 0\end{array}$

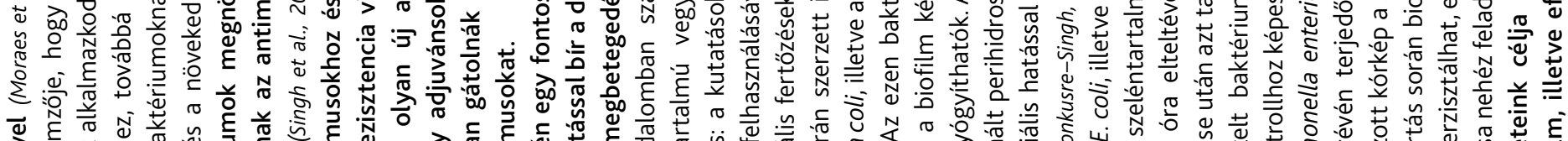

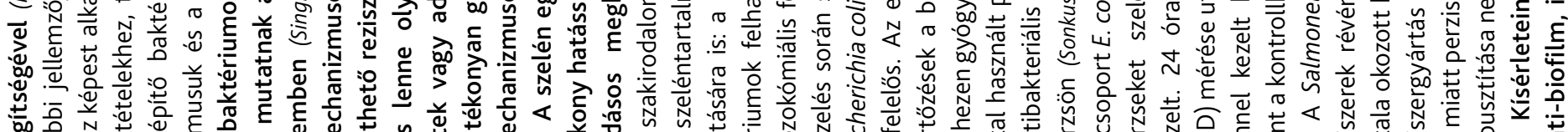

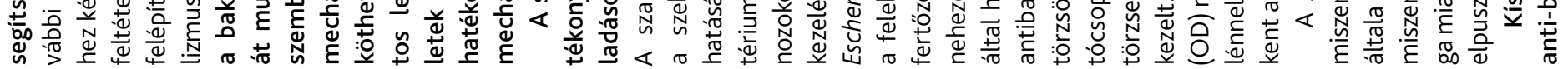

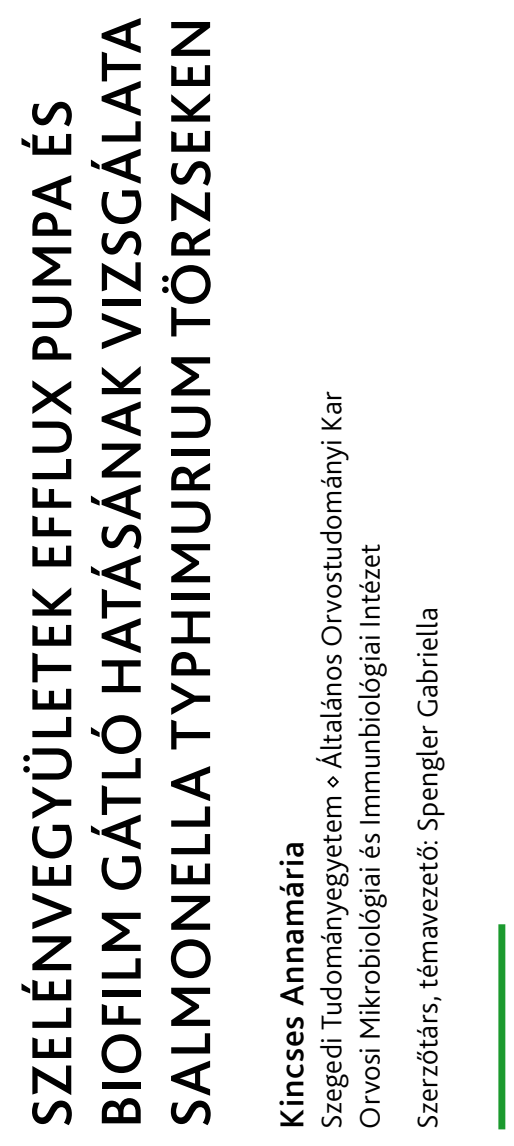

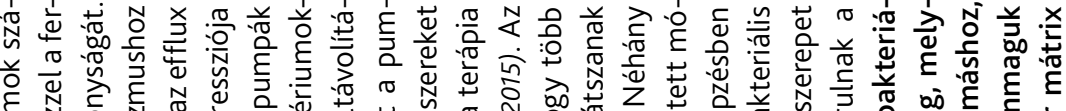

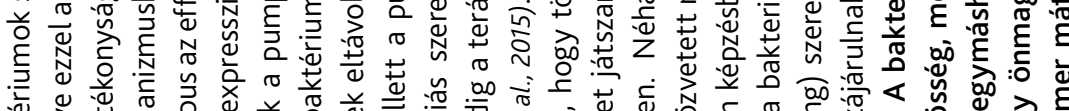

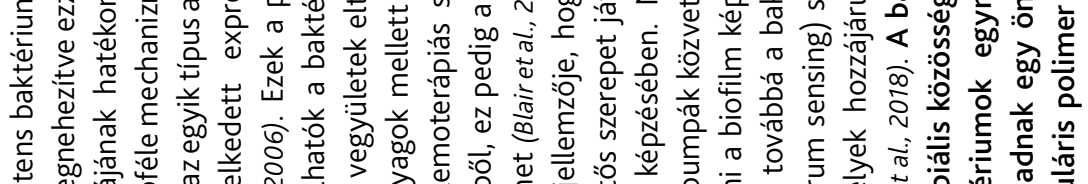

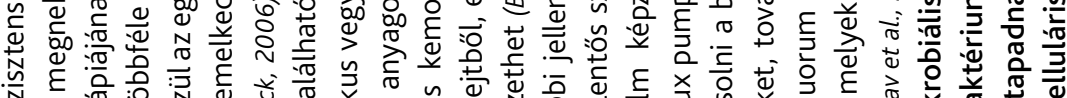

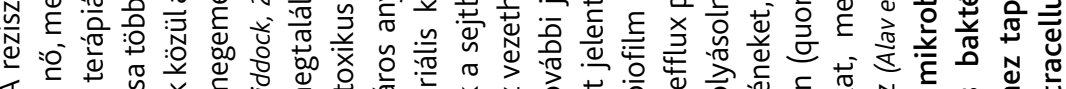

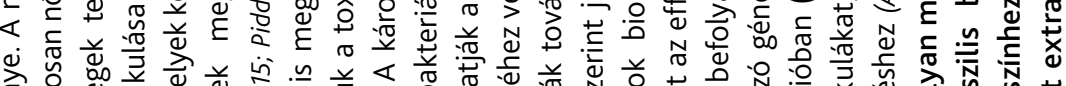

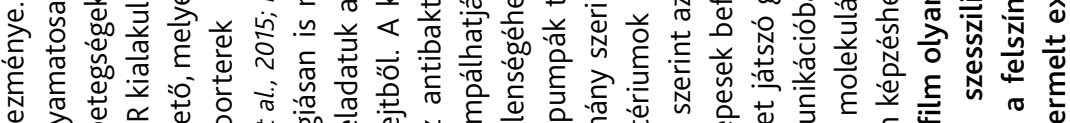

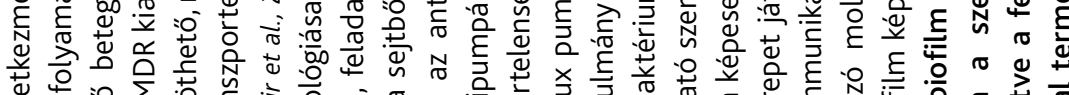

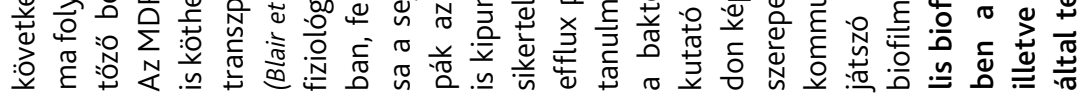

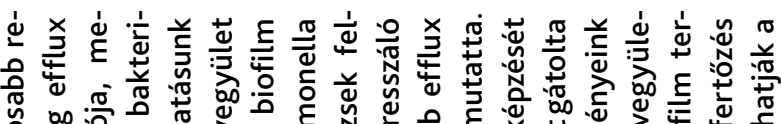

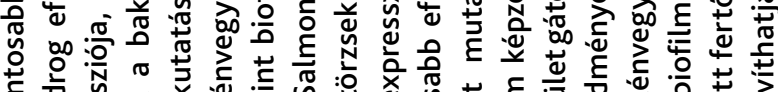

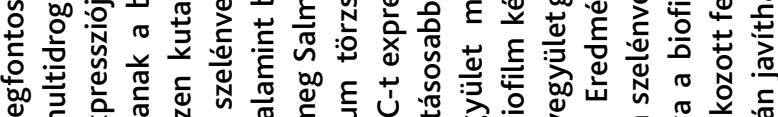

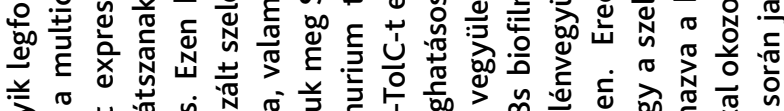

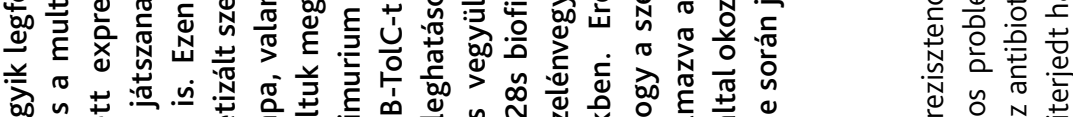

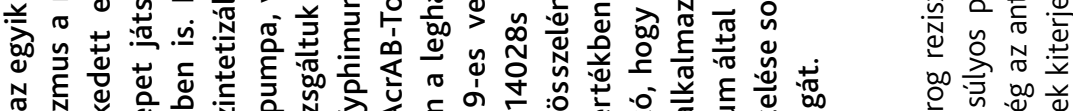
N है

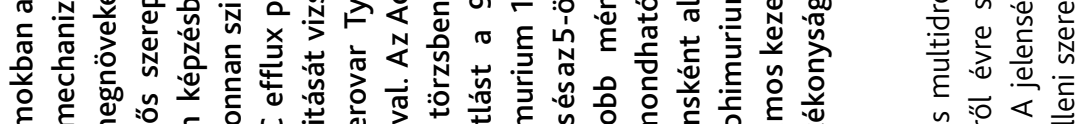

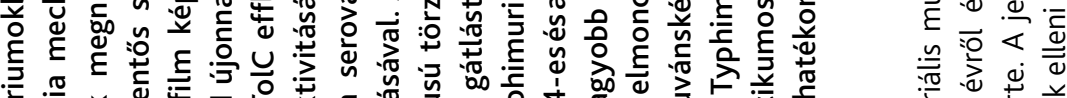

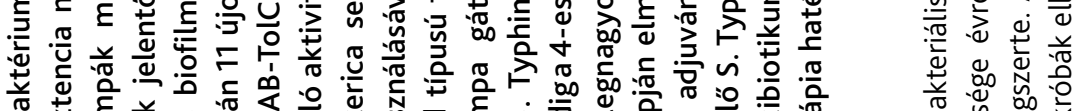

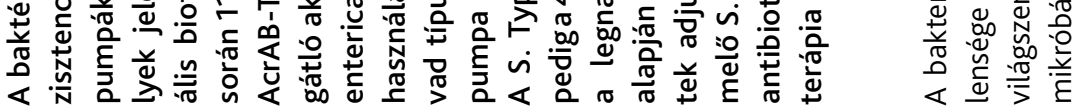




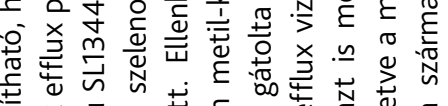

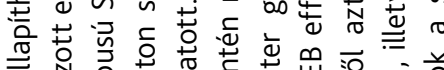

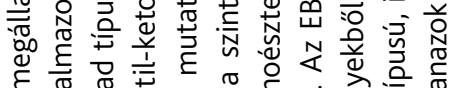

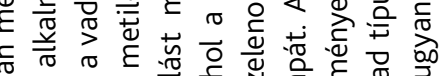

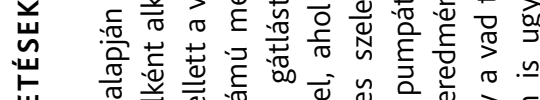

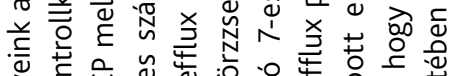

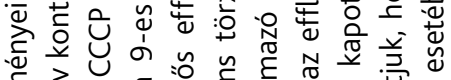

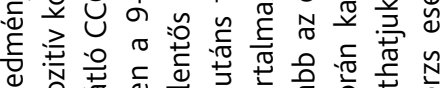

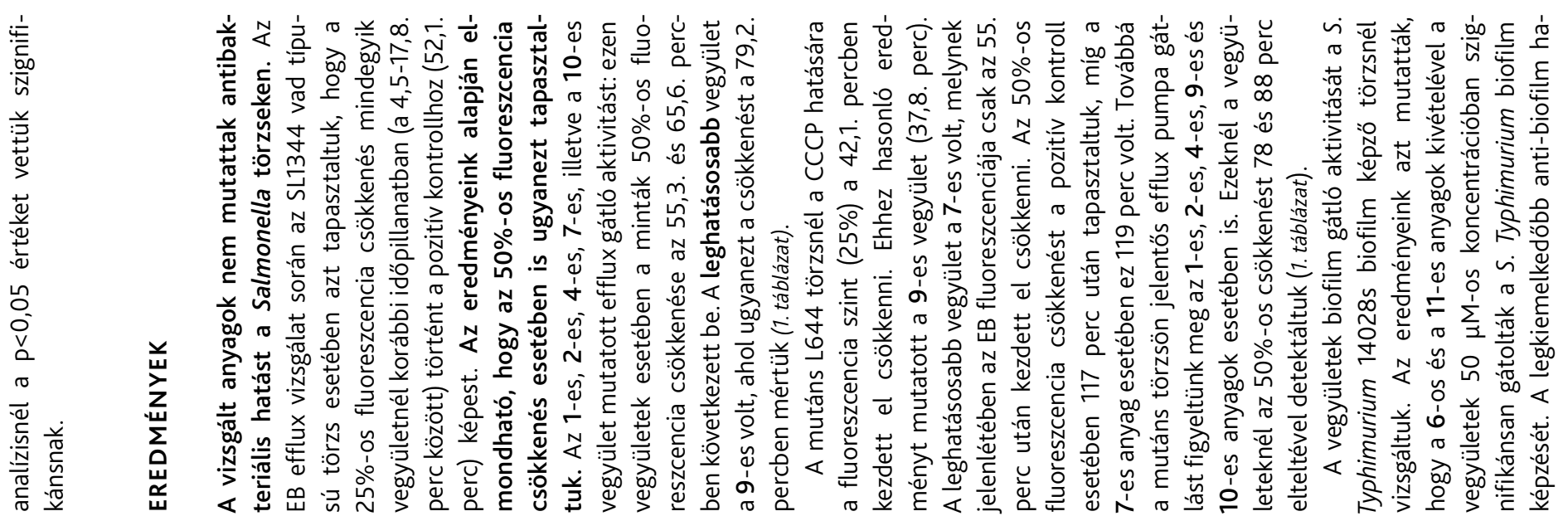

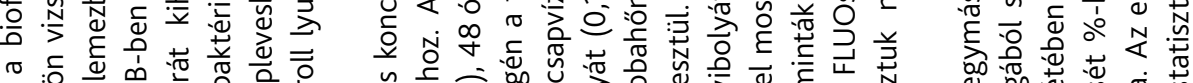

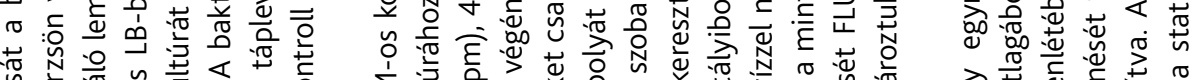

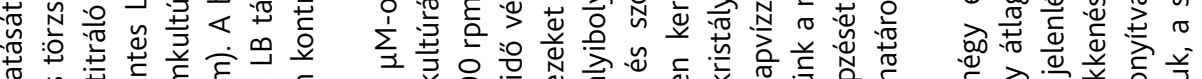

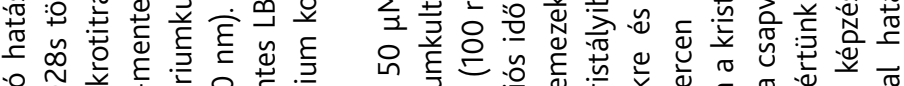

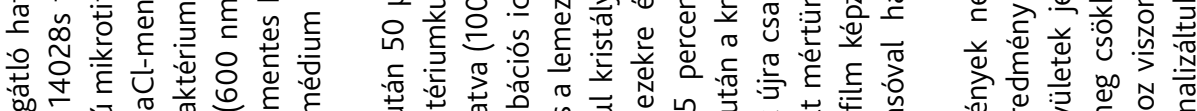

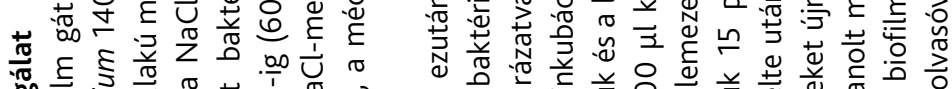

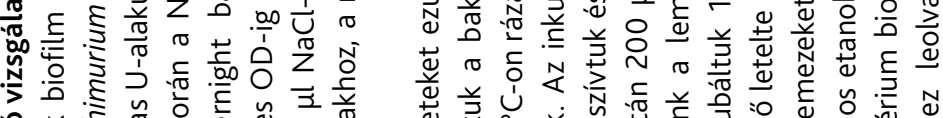

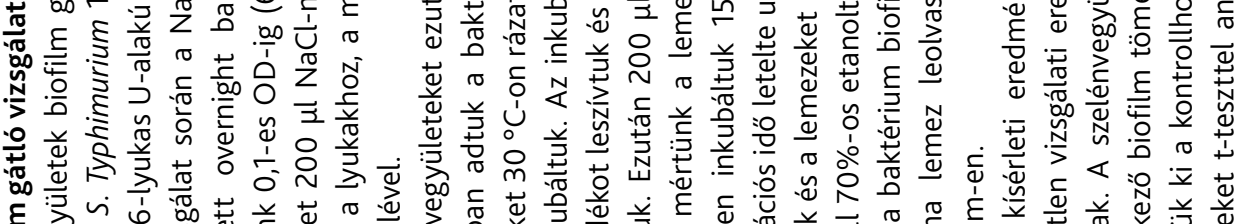

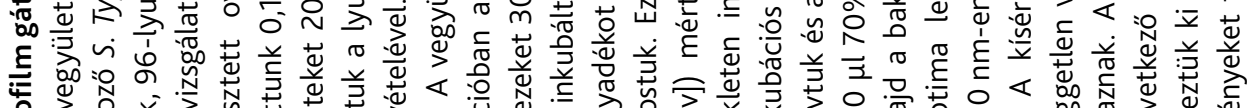

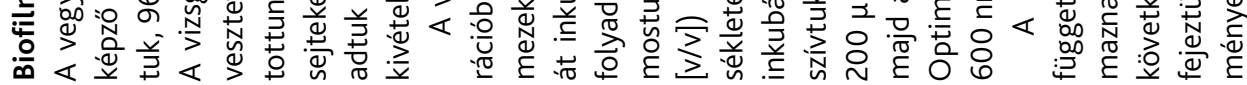

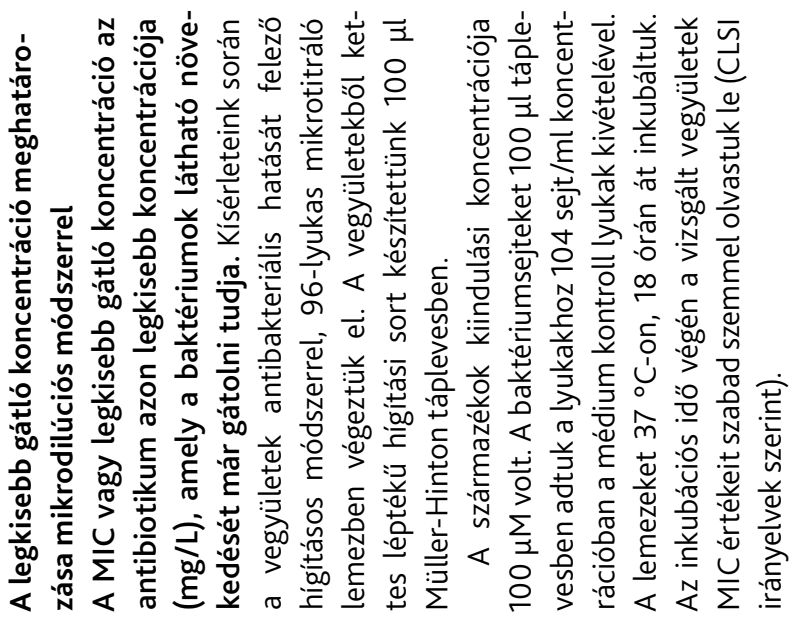

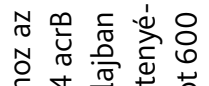

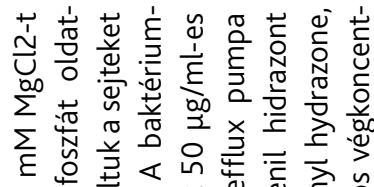

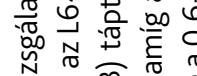

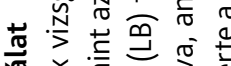

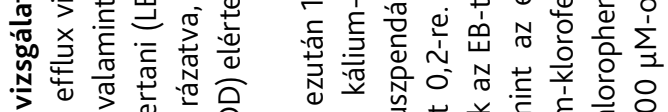

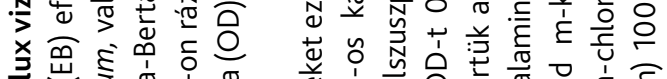

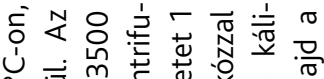

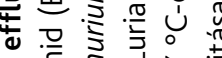

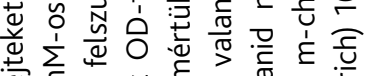

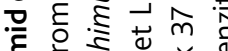
$\begin{array}{llll} & \\ 0\end{array}$

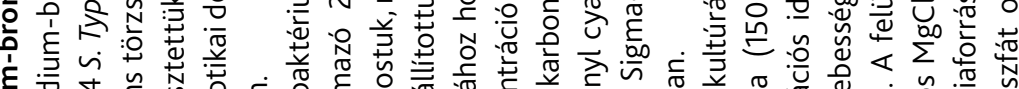

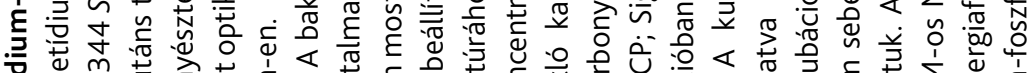

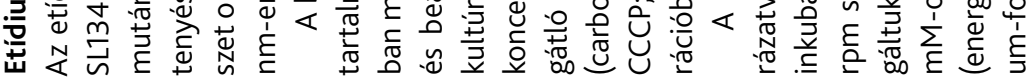




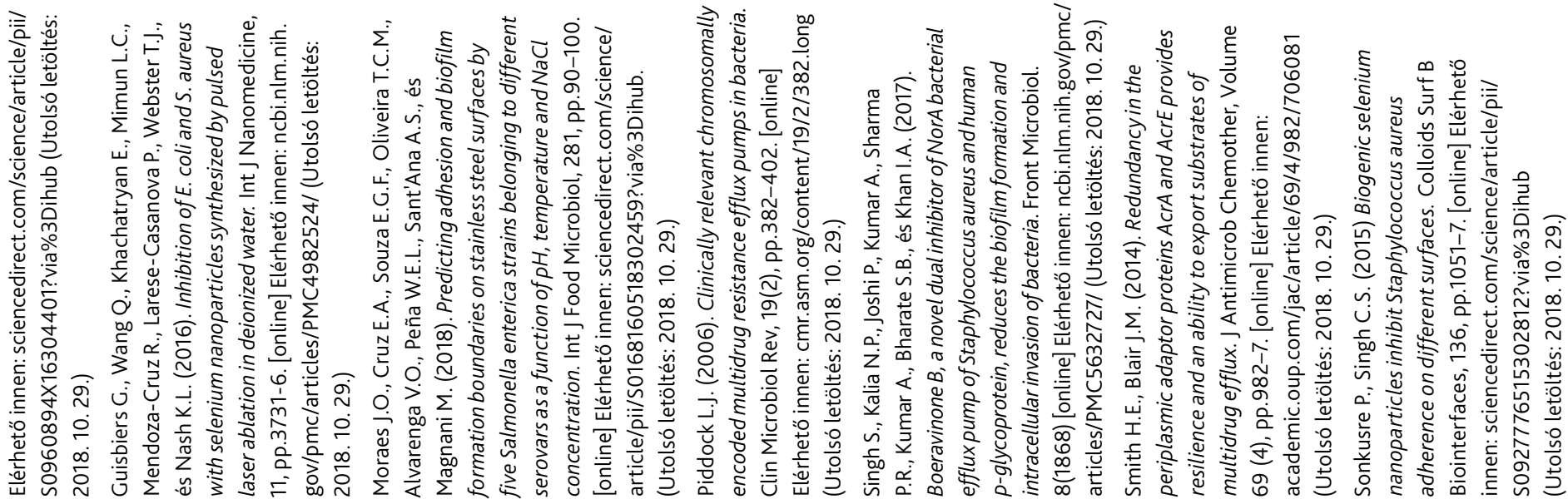

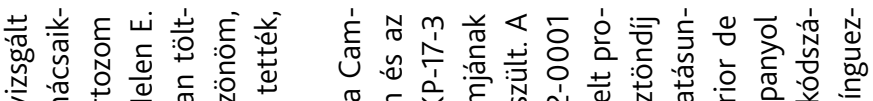

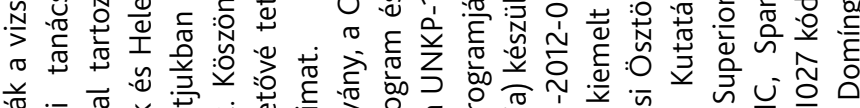

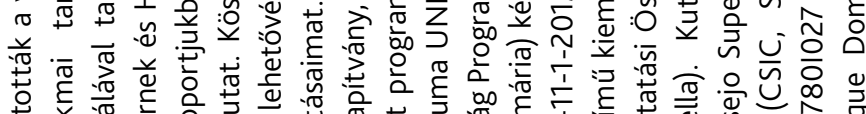

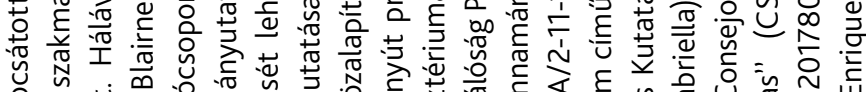

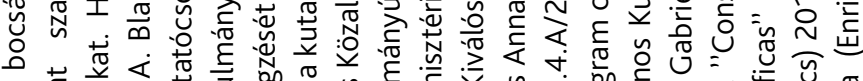

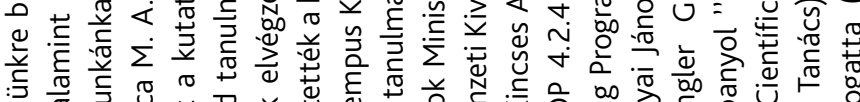

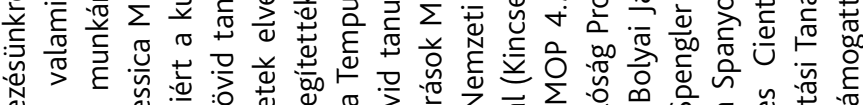

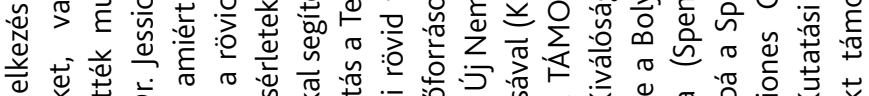

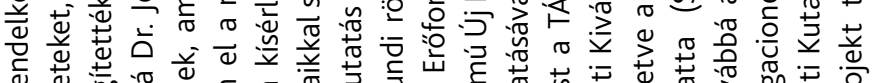

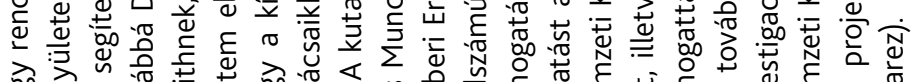

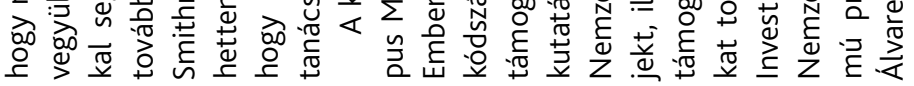

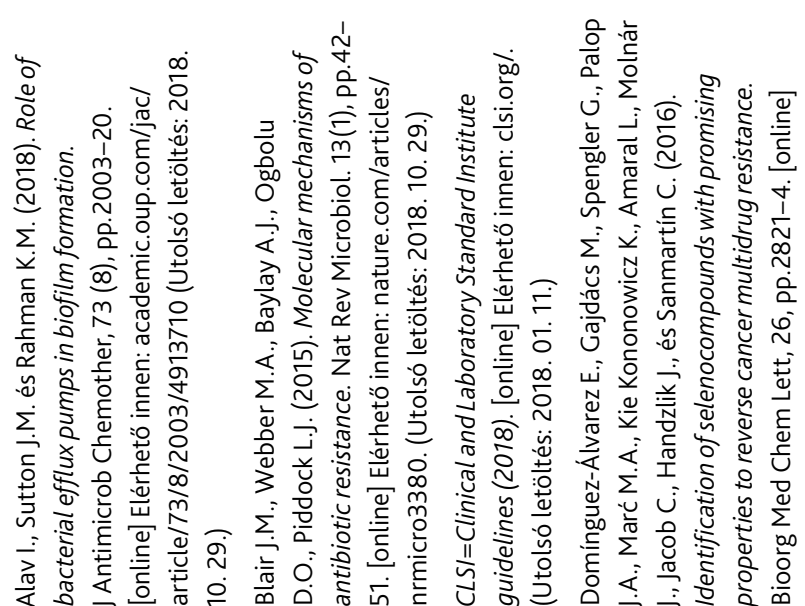

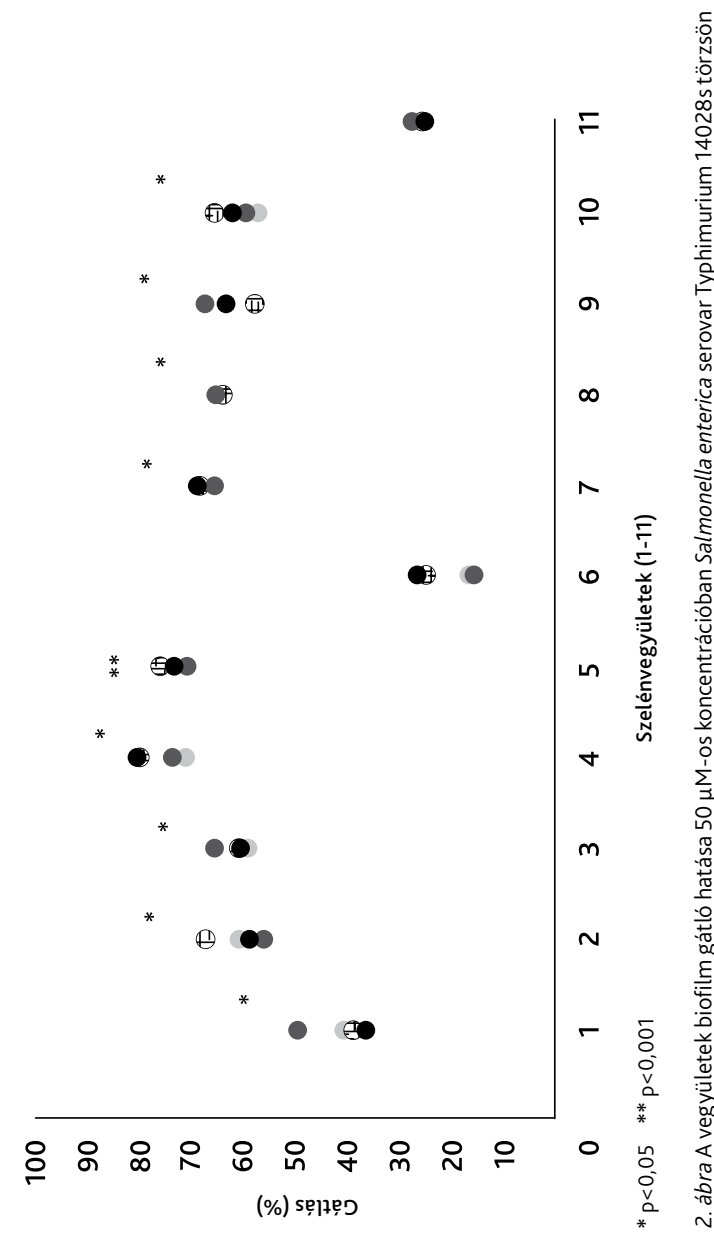

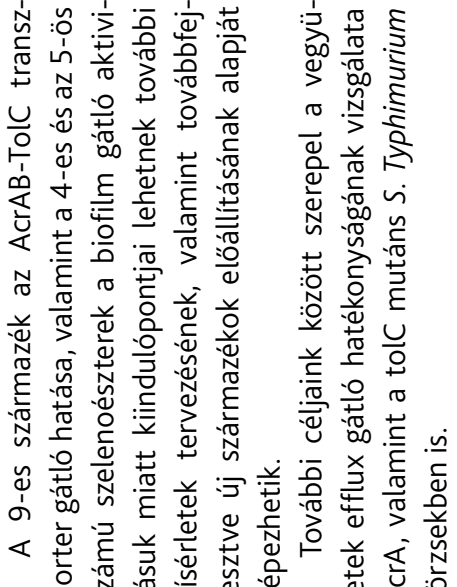

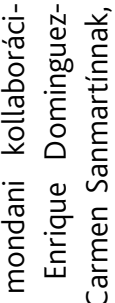

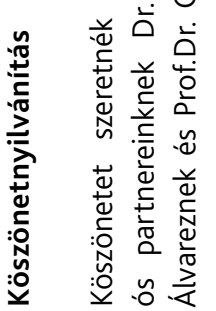

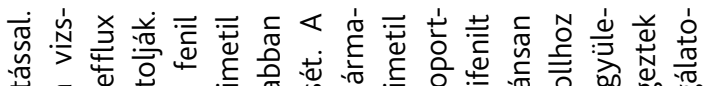

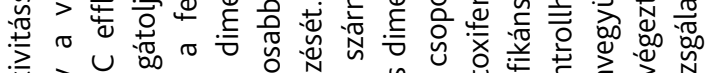

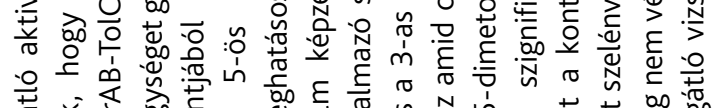

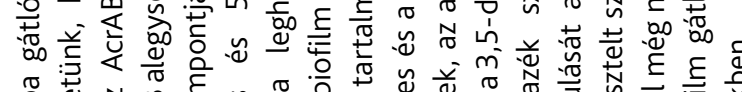

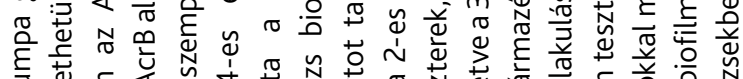

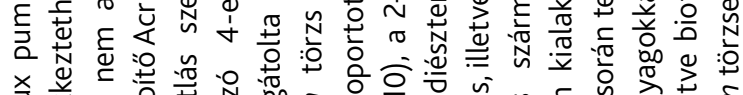

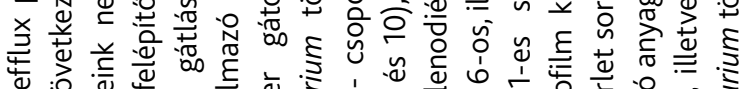

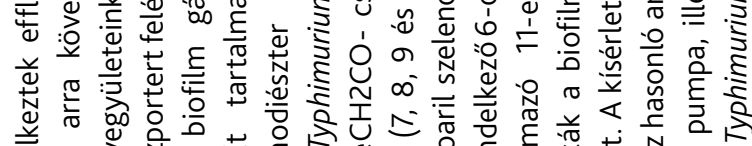

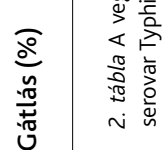

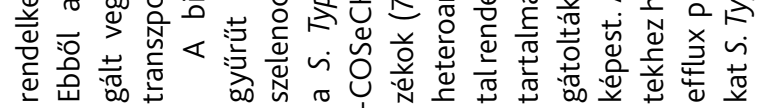

